\begin{abstract}
UNIVERSIDADE DE SÃO PAULO
FACULDADE DE FILOSOFIA, LETRAS E CIÊNCIAS HUMANAS

DEPARTAMENTO DE LETRAS CLÁSSICAS E VERNÁCULAS

PROGRAMA DE PÓS-GRADUAÇÃO EM FILOLOGIA E LÍNGUA PORTUGUESA
\end{abstract}

Francisco Gilberto Labate

\title{
VOCABULÁRIO DA ECONOMIA: \\ FORMAS DE APRESENTAÇÃO DOS ESTRANGEIRISMOS
}

Orientadora: Prof. ${ }^{a}$ Dr. ${ }^{a}$ Ieda Maria Alves 
UNIVERSIDADE DE SÃO PAULO

FACULDADE DE FILOSOFIA, LETRAS E CIÊNCIAS HUMANAS

DEPARTAMENTO DE LETRAS CLÁSSICAS E VERNÁCULAS

PROGRAMA DE PÓS-GRADUAÇÃO EM FILOLOGIA E LÍNGUA PORTUGUESA

\section{VOCABULÁRIO DA ECONOMIA: FORMAS DE APRESENTAÇÃO DOS ESTRANGEIRISMOS}

\section{Francisco Gilberto Labate}

Dissertação de Mestrado apresentada ao Departamento de Letras Clássicas e Vernáculas, Programa de Pós-Graduação em Filologia e Língua Portuguesa da Faculdade de Filosofia, Letras e Ciências Humanas da Universidade de São Paulo, como requisito parcial para a obtenção do título de Mestre em Filologia e Língua Portuguesa.

Orientadora: Prof. ${ }^{\mathrm{a}}$ Dr. ${ }^{\mathrm{a}}$ Ieda Maria Alves

São Paulo 2008 
BANCA EXAMINADORA 


\section{Agradecimentos}

À Prof.a Dr.a Ieda Maria Alves, pela orientação, estímulo e dedicação.

Aos que contribuíram de alguma forma para a consecução deste trabalho: ao Cesar, ao Julio, sempre disponível, à turma da $4^{\mathrm{a}}$.-feira, pela amizade e pelo debate intelectual; à Rosi, pelo incentivo.

À Marilda, ao Ítalo, ao Sergio, à Dora.

À Bia.

À Sonia, pela presença e apoio permanente. 


\section{Resumo}

A Dissertação tem por objetivo analisar a maneira como os estrangeirismos, elementos exteriores ao léxico vernacular, são apresentados na língua portuguesa, na área específica da Economia.

Em uma primeira parte do trabalho, desenvolvemos considerações de ordem teórica, referente à terminologia e à metalingugem. Tomando por objetivo da análise os termos constantes da Base de Termos da Economia, constituída no âmbito do Projeto Observatório de Neologismos do Português Brasileiro Contemporâneo (projeto TermNeo), verificamos que, estatisticamente, cerca de $8,4 \%$ dos termos se constituem em estrangeirismos

Os estrangeirismos coletados foram posteriormente classificados de acordo com a tipologia de sua apresentação. Por meio de análise dos contextos em que ocorreram, os respectivos estrangeirismos foram classificados em duzentos e vinte e nove tipos de apresentação diferentes e, a seguir, agrupados em nove categorias. Procedemos à análise de algumas formas de apresentação, procurando distinguir as formas que implicavam a utilização de recursos gráficos ou de língua-objeto, bem como os de metaliguagem.

Ao final, foram feitas considerações sobre a questão da metalinguagem.

Palavras-Chave: economia, estrangeirismo, terminologia, metalinguagem, tipologia 


\begin{abstract}
The objective of the dissertation was to analyse how terms brought in from other languages are presented in Portuguese, specifically, in the area of Economics.

In the first part of the dissertation we presented theoretical considerations on terminology and metalanguage. The terms analyzed were those included in the Base de Termos da Economia [Base of Economic Terms] drawn up as part of the project known as Observatório de Neologismos do Português Brasileiro Contemporâneo (Projeto TermNeo). We found that, statistically, approximately $8.4 \%$ of the entries consisted of foreign terms.

The terms collected were later classified according to the typology of their presentation. Based on an analysis of the contexts where they occurred, the terms were classified into two hundred and twenty-nine different types of presentation and then grouped into nine categories. Several of the forms of presentation were analyzed in an attempt to distinguish those that imply the use of graphic resources or object-language, as well as those of metalanguage.
\end{abstract}

At the end considerations were presented on the question of metalanguage.

Key-words: economics, foreign terms, terminology, metalanguage, typology 
I. INTRODUÇÃO. 1

1.1. Economia e Globalização .............................................................. 1

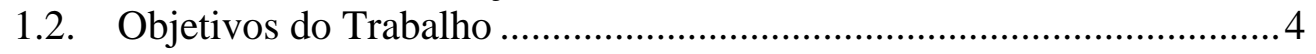

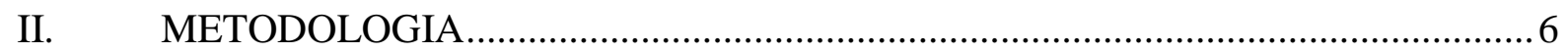

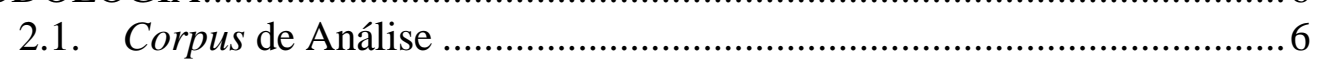

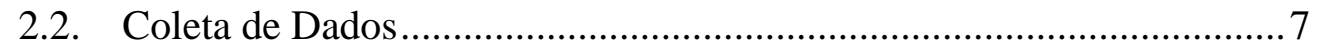

2.3. Procedimentos de Análise ................................................................ 10

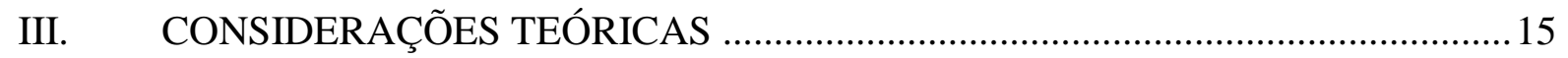

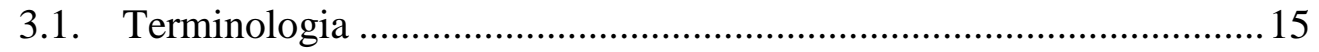

3.2. Noções básicas - Conceito, Termo e Definição na Língua de

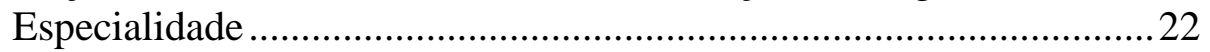

3.3. Língua Geral / Língua de Especialidade..............................................22

3.3.1. Economia e Língua de Especialidade...................................... 30

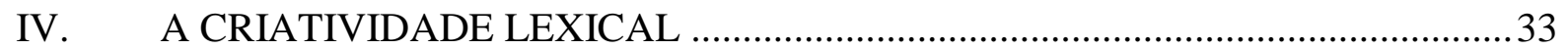

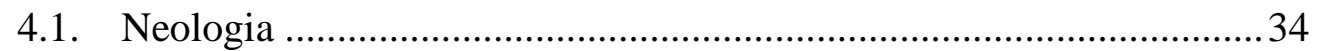

4.1.1. Neologia nas Línguas de Especialidade .................................38

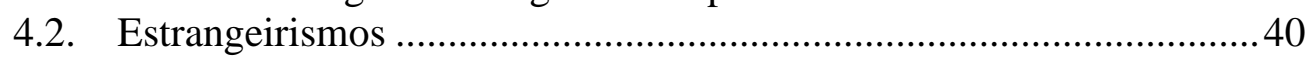

4.3. Empréstimos ......................................................................... 43

4.3.1. Empréstimos nas Línguas de Especialidade ............................45

V. A INTEGRAÇÃO DOS ESTRANGEIRISMOS AO PORTUGUÊS ......................47

VI. FORMAS DE APRESENTAÇÃO DOS ESTRANGEIRISMOS ............................54

6.1. A Questão da Metalinguagem ..........................................................54

6.2. Tipologia dos Discursos Científicos e Definição ...............................63

6.3. Tipologia das Formas de Apresentação dos Estrangeirismos ..............72

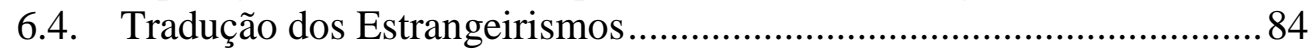

6.5. Análises de Algumas Formas de Apresentação...................................92

6.6. O Discurso Jornalístico................................................................. 106

6.7. Categorização das Formas de Apresentação ..................................... 110

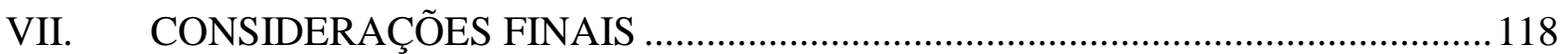

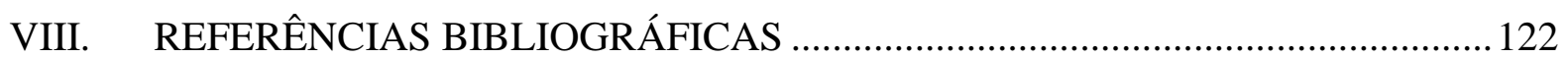




\section{INTRODUÇÃO}

\subsection{Economia e Globalização}

As atividades econômicas sempre exerceram um papel preponderante em todas as sociedades. A necessidade de trocas, o comércio entre cidadãos e entre diferentes povos, tornaram essas atividades imprescindíveis e levaram ao desenvolvimento da Economia como ciência.

A partir da segunda metade do século XX, especialmente, as atividades econômicas inserem-se em um mundo em que as comunicações foram-se tornando mais rápidas e mais acessíveis aos cidadãos de todos os países. O conceito de globalização, ou mundialização, passou a representar as mudanças que a sociedade foi sofrendo.

Falar em globalização é evocar o domínio de um sistema econômico, o capitalismo, sobre o espaço global. Esse domínio manifesta-se, em primeiro lugar, no plano geopolítico. Com a derrocada do bloco soviético, desapareceu um dos mais maciços obstáculos à expansão do capitalismo. Onde subsistem regimes comunistas, como na China, estes devem sua permanência, em parte, à implementação de políticas de abertura de mercado e ao afluxo de capitais por ele suscitado. Em outras partes, como na África e na América Latina, a penetração do capitalismo tem sido encorajada sistematicamente pelas instituições financeiras internacionais, o Fundo Monetário Internacional (FMI) e o Banco Mundial. Colocadas em posição de força pela crise da dívida que atingiu essas regiões no início da década de 1980, tais instituições mantêm todo o seu poder a serviço da reforma das instituições e das políticas econômicas dos países devedores, reforma essa cujo objetivo explícito é promover a difusão da lógica de mercado.

Entretanto, esse domínio universal do capitalismo ultrapassa em muito o campo geopolítico. Não se reduz ao triunfo de um bloco de estados sobre outro, nem mesmo de um modo de produção sobre seus concorrentes. Tende, de fato, a transcender a lógica de um sistema interestatal, substituindo-a por uma lógica de redes transnacionais. Expressão da 
expansão espacial do capitalismo, que agora se justapõe aos limites do globo, a globalização é, também, e acima de tudo, um processo de contornar, fatiar e, finalmente, desmantelar as fronteiras físicas e regulamentadoras que representam um obstáculo à acumulação do capital em escala mundial. Nesse sentido, a economia global é mais do que uma simples economia internacional. Esta, respeitosa das soberanias nacionais, relacionava as partes autônomas de um todo ainda não integrado, mediante fluxos de comércio, investimento e crédito. Correspondia a uma fase específica da história do capitalismo, no curso da qual os mercados nacionais, amplamente protegidos, até mesmo regulados pelos estados, constituíam a base primordial da acumulação de capital. No essencial, tanto o comércio quanto o investimento internacional continuavam baseados em critérios de complementaridade.

O fenômeno da globalização traduz mais uma mutação do que uma continuidade nesse processo. A crescente integração das partes constitutivas do todo da economia mundial dá-lhe uma dinâmica própria, que escapa cada vez mais do domínio dos Estados e atinge certos atributos essenciais de sua soberania, como o controle monetário e a gestão das finanças públicas. A mobilidade de informação, de imagens e de capitais, levada a extremos pela revolução das comunicações, torna anacrônicas em diversas esferas as noções de fronteira e de território. Em contrapartida, encoraja a organização da produção em uma base transnacional e concorre para a globalização das normas de consumo. As complementaridades que, desde a década de 1950, fundamentavam a circulação de bens e capitais, foram substituídas por uma concorrência generalizada pelo controle dos mercados e dos recursos (matérias-primas, mão-de-obra, redes de distribuição, competências, massa cinzenta, poupança etc.).

Por certo, a instância nacional está longe de haver desaparecido, e o sistema interestatal ainda tem um bom tempo pela frente. Mas, de ora em diante, ocupam o segundo plano de uma cena econômica dominada por lógicas integradoras privadas, às quais os Estados tentam fazer frente de alguma forma. Desse ponto de vista, não poderia ser maior a importância da perspectiva histórica. Restituída ao plano da longa duração, a era da conformação da economia global por Estados-nação rivais poderia muito bem aparecer apenas como um longo parêntese histórico, produto ao mesmo tempo frágil e explosivo da aliança selada entre os comerciantes e os príncipes da era mercantil. A globalização inscrever-se-ia, 
assim, numa tendência mais longa, a da submissão progressiva de todo o espaço físico e social à lei do capital, lei de acumulação sem fim que constitui a finalidade última do sistema econômico inventado há cerca de mil anos pelas cidades mercantis do Mediterrâneo.

A essas observações, colhidas em Adda (2004:XI-XIII), lembremos que a globalização apresenta-se como processo que implica uma mudança que repercute nos diferentes povos do mundo, em maior ou menor escala, dependendo do grau de desenvolvimento de cada país. A globalização constitui marca de modernidade. Esta, por sua vez, é considerada por Giddens (1991:69) como 'inerentemente globalizante', visto que,

"na era moderna, o nível de distanciamento tempo-espaço é muito maior do que em qualquer período precedente, e as relações entre formas sociais e eventos locais e distantes tornam-se correspondentemente 'alongadas"'.

Ocorre a criação de novas necessidades de expansão do sistema capitalista, o qual, por sua natureza dinâmica e competitiva, precisa encontrar formas de sobrevivência dentro e fora de limites locais. Esse quadro modifica, principalmente, a lógica do trabalho, gerando conseqüências nas várias instâncias da sociedade, inclusive na educação e na cultura; porém, isso não significa uma situação de homogeneização cultural, mesmo porque, como defende Ortiz (2000), a cultura não se globaliza, mas se mundializa e
"uma cultura mundializada não implica o aniquilamento das outras manifestações culturais, ela coabita com elas e delas se alimenta. Um exemplo: a língua” (Ortiz, 2000:27).

Ortiz sustenta suas colocações utilizando-se da situação de uso do idioma inglês de forma cada vez mais disseminada, classificando-o como uma língua mundial; nas palavras do autor,

“prefiro dizer que o inglês é uma 'língua mundial'. Sua transversalidade revela e exprime a globalização da vida moderna; sua 
mundialidade preserva os outros idiomas no interior desse espaço transglóssico" (2000:29).

O inglês também vem se consolidando como língua global em virtude do fenômeno da financeirização: os ativos financeiros adquiriram uma importância sem precedentes na história do capitalismo mundial. Esse processo extrapolou as economias nacionais, intensificado pela liberalização dos mercados cambiais e pela desregulamentação dos fluxos de capitais.

A transnacionalização das aplicações financeiras faz também com que uma gama fundamental de informações circulem pela Internet no idioma em destaque, o inglês.

\subsection{Objetivos do Trabalho}

Em razão da consolidação crescente da língua inglesa como língua global, este trabalho tem por objetivo principal detectar e analisar a incidência de estrangeirismos na redação de textos, em um corpus de divulgação jornalística da área de Economia.

Como objetivos secundários, pretendemos estudar os recursos e opções de apresentação que regem a introdução dos estrangeirismos: Que estratégias de apresentação são adotadas? Como se faz a apresentação de um termo, freqüentemente desconhecido pelo destinatário? Que recursos da língua (ou da metalíngua) são ativados para a legitimação (ou não) da apresentação de estrangeirismos?

O estrangeirismo representa um tipo de neologismo que consiste no emprego, na língua de uma comunidade, de elementos provenientes de outras línguas. No caso brasileiro, representa o uso de palavras estrangeiras no português. Trata-se de fenômeno constante no contato entre comunidades lingüísticas, constituindo, também, um tipo de empréstimo. É no léxico que esse fenômeno é mais freqüente. Weinreich (1974:56), explorando as causas do empréstimo lexical, refere-se à necessidade de designar novas coisas, pessoas, lugares e conceitos, lembrando que este processo é, obviamente, uma causa universal para a inovação léxica. Acrescenta, ainda, o autor (1974:56): 
“O vocabulário de uma língua, estruturado de maneira significativamente mais solta do que seus fonemas e sua gramática, é, sem dúvida, o domínio do empréstimo por excelência”.

Os estrangeirismos, portanto, não alteram as estruturas da língua, ou seja, a sua gramática, e por isso não são capazes de destruí-la. Os estrangeirismos atuam no nível mais superficial da língua, que é o léxico.

A necessidade de contínua expansão que a Economia se auto-impõe, bem como a busca incessante de novos mercados, implica uma interação comunicacional que se estende internacionalmente. A linguagem é um dos veículos de obtenção dessas metas.

O que ocorre no plano da Economia ocorre homologamente no plano da linguagem: as potências detentoras de maior poder divulgam, exportam e impõem sua língua através das múltiplas relações que ocorrem globalmente. A tecnologia e o poderio econômico expressamse através da língua dominante que, nos últimos anos, tem sido o inglês.

Apesar de alguns verem com naturalidade a penetração de estrangeirismos em outras línguas, ou por serem inevitáveis ou por se constituírem em enriquecimento da língua-alvo, a noção de estrangeirismo, contudo, lembra-nos Faraco (2004:15-17), confere ao empréstimo uma suspeita de identidade alienígena, carregada de valores simbólicos relacionados aos falantes da língua que origina o empréstimo. Os vocabulários de todas as línguas são o resultado de uma história de interação, pacífica ou não, com outros povos e culturas e, portanto, com outras línguas. Receber palavras de origem estrangeira sob forma de empréstimo não tem a ver com a soberania político-econômica. Os idiomas são propícios para o exercício e o desenvolvimento da interculturalidade e não faz sentido restringi-los aos limites de um país ou de uma nacionalidade. 


\section{METODOLOGIA}

Para analisar os recursos e opções de apresentação que presidem a introdução dos estrangeirismos na redação de textos, em um corpus de divulgação jornalística da área de Economia, pretendemos constituir tipologias, derivadas dos contextos específicos analisados (campo "contexto" das respectivas fichas terminológicas), para que possamos compreender e analisar suas características lingüísticas e categorizar sua natureza de língua ou de metalíngua.

Tomando como objetivo de nossa análise os termos constantes da Base de termos da Economia, constituída no âmbito do Projeto Observatório de Neologismos Científicos do Português Contemporâneo, projeto TermNeo, verificamos que, estatisticamente, cerca de $8,4 \%$ dos termos se constituem em estrangeirismos.

As várias fases para a realização deste trabalho foram divididas em três partes: corpus de análise, coleta de dados e procedimentos de análise.

Veremos, a seguir, o desenvolvimento de cada um desses itens.

\subsection{Corpus de Análise}

A maioria dos termos do corpus que serviu de base para nosso trabalho refere-se ao período que vai de 1991 até meados de 2007. São exemplos extraídos da imprensa brasileira, que se inserem no âmbito da Base de Termos da Economia, Projeto Observatório de Neologismos Científicos e Técnicos do Português Contemporâneo (TermNeo), coordenado pela Prof. ${ }^{a}$ Dr ${ }^{a}$ Ieda M. Alves. A coleta dos termos foi efetuada por alunos de Graduação do Curso de Letras da Faculdade Filosofia, Letras e Ciências Humanas da Universidade de São Paulo, bolsistas de Iniciação Científica do CNPq (Conselho Nacional de Desenvolvimento Científico e Tecnológico) e da FAPESP (Fundação de Amparo à Pesquisa do Estado de São Paulo). 
As unidades terminológicas apresentadas estão todas contextualizadas e seguidas de suas referências: nome do jornal ou revista, data, página e coluna. Esses termos foram recolhidos em periódicos e revistas de caráter geral ou específico; no primeiro caso, eles se referem a jornais de grande circulação nacional, tais como Folha de S. Paulo, O Estado de S. Paulo, $O$ Globo, e, no segundo caso, a revistas e jornais mais especializados, como Exame, Conjuntura Econômica e Gazeta Mercantil.

O corpus que pesquisamos apresenta dados suficientes para os objetivos de nossa pesquisa: possui 4.548 termos, com cerca de 382 unidades terminológicas caracterizadas como estrangeirismos no campo "observações lingüísticas" das respectivas Fichas Terminológicas.

Tivemos que necessariamente limitar o número de contextos a serem examinados (cerca de 962 para a totalidade dos 382 termos). Buscamos, entretanto, na medida do possível, pesquisar pelo menos um contexto que revele cada uma das formas de apresentação dos estrangeirismos encontrados.

Também não poderíamos estender a análise voltada para um corpus científico, porque esse tipo de procedimento excederia os limites da nossa pesquisa, ampliando de forma considerável o tempo e os objetivos deste trabalho.

\subsection{Coleta de Dados}

Coletamos os 382 estrangeirismos para procedermos à analise dessas ocorrências na Base. Esses termos, conforme já mencionamos, são provenientes de um corpus de divulgação (constituído pelos jornais Folha de S. Paulo, O Estado de S.Paulo, O Globo, Gazeta Mercantil; revistas Exame e Conjuntura Econômica).

A Base, criada em 1991 (no programa Microsoft Access), apresenta 4.548 unidades (desde sua criação sob forma informatizada até meados de 2007). Esses termos coletados estão transcritos em uma ficha terminológica, que possui os seguintes campos: termo, referências gramaticais, sigla ou forma abreviada, variantes, contexto(s) e referências do(s) 
contexto(s), definição, dados fraseológicos, observações lingüísticas, observações enciclopédicas, termos relacionados, sinônimos, autor da ficha, revisor da ficha e data de registro. Podemos encontrar também na ficha terminológica o campo marca de ponderação, que atesta o registro lexicográfico (no caso de sua existência) do termo em alguns dicionários de língua geral e especializados tais como Dicionário Houaiss da língua portuguesa, Novo dicionário Aurélio da língua portuguesa, MICHAELIS: moderno dicionário da língua portuguesa, Glossário de termos neológicos da Economia e Novo dicionário de Economia.

Entre as siglas encontradas nos exemplos de fichas terminológicas transcritas a seguir, encontramos: FSP $=$ Folha de $S$. Paulo, ESP $=O$ Estado de S.Paulo, G $=O$ Globo, GM = Gazeta Mercantil; revistas: Ex = Exame e CE = Conjuntura Econômica; sf = substantivo feminino, p. = página; $\mathrm{c} .=$ coluna; $\mathrm{s}=$ substantivo, adj = adjetivo. Extraímos da Base dois exemplos de fichas cujos termos constituem formações sintagmáticas. Nas "observações lingüísticas" complementares de cada um desses termos, aparece a referência a estrangeirismo, quando for o caso.

A seguir registramos dois exemplos de ficha terminológica, sendo a segunda referente a estrangeirismo:

\section{1.. FICHA TERMINOLÓGICA}

ID:

4363

Área: $\quad$ Economia

Subárea:

Termo:

desovernightização

Variante(s):

Sigla ou forma abreviada:

Referências gramaticais: $\mathrm{sf}$

Marca de ponderação:

Contexto(s):

A <"Desovernightização"> da economia (tít.) Paulo Guedes

Imagine uma economia "overnightizada". Bilhões de dólares em aplicações de 
curtíssimo prazo. (...) E novos fluxos de poupança assustada continuam buscando refúgio por uma noite, pois quem aplicou a prazos mais longos em pré-fixados foi "tablitado", quem aplicou em "pós-fixados" foi "desindexado", e mesmo quem aplicou por um dia foi seqüestrado, durante a noite, por dezoito meses. Imagine agora que o governo examine duas alternativas para "desovernightizar" esta economia. [Paulo Guedes]

Referência: (FSP, 03-03-91, p. 3-2, c. 5 e 6)

Definição:

Observações lingüísticas: derivação sufixal

Observações complementares: v neológico + -ção

Dados fraseológicos:

Observações enciclopédicas:

Termos relacionados:

Sinônimos:

Data: 11-jan-05

Autor da ficha: Juliana

Autor do registro

Data de atualização: 10-mar-05

Revisor leda

\section{2a . FICHA TERMINOLÓGICA}

ID:

Área:

Economia

Subárea:

Termo: banker acceptance

Variante(s):

Sigla ou forma abreviada: 
Referências gramaticais: s

Marca de ponderação:

Contexto(s):

Nos Estados Unidos, os conhecidos aceites bancários <bankers acceptances>, papéis comerciais (commercial papers), debêntures agrícolas, notas de exportação e até mesmo notas promissórias lastreadas por produtos agrícolas admitidos em depósito são títulos amplamente aceitos pelo mercado secundário. - (CE, 01-95, p. 43, c. 1)

Referência: (CE, 01-95, p. 43, c. 1)

Definição:

Observações lingüísticas: estrangeirismo

Observações complementares: de origem inglesa

Dados fraseológicos:

Observações enciclopédicas: No início, há cerca de 70 anos, para estimular esses títulos (predominantemente no caso dos aceites bancários), e como forma de financiar a agricultura, o Sistema de Reserva Federal do Estado de Nova lorque (uma espécie de banco central do estado) isentou o volume dessas operações de depósitos compulsórios, concedeu-lhes taxas de redesconto preferenciais e fez compromisso de recompra desses títulos às taxas vigentes. O resultado foi um impulso notável desse tipo de operação.

Termos relacionados:

Sinônimos:

Data:

27-mar-95

Autor da ficha: $\quad$ Elaine

Autor do registro

Data de atualização: $\quad$ 18-set-02

Revisor: $\quad$ leda

\subsection{Procedimentos de Análise}

As formas de apresentação dos estrangeirismos foram selecionadas e analisadas tendo em vista os fundamentos da metalinguagem. Em seu estudo sobre as funções da linguagem, Jakobson (1973:127) considera função metalingüística a que caracteriza a linguagem falando da linguagem, voltando-se sobre si mesma. Essa função reenvia o código utilizado à língua e 
seus elementos constitutivos. No nosso estudo, o código é representado por lexias, simples ou compostas, locuções e expressões que preenchem a função de apresentação dos estrangeirismos.

Duas obras fundamentais publicadas em um intervalo de dezessete anos constituem nossa referência de base. A primeira, publicada inicialmente em 1978, é Le Métalangage de J. Rey-Debove, que inaugura a problemática lingüística da autonímia, explorando suas características semióticas. Mais tarde, em 1995, nos dois volumes de Ces mots qui ne vont pas de soi, J. Authier-Revuz estuda, detalhadamente, na linguagem corrente, os fenômenos identificados por J. Rey-Debove sob o nome de Conotações Autonímicas, apresentando-os como manifestações espontâneas do dire en train de se faire que decorrem de uma modalidade meta-enunciativa.

Rey-Debove preconizava a unificação da metalinguagem e da autonímia em uma única problemática semiótica. Lamentando o fato de que "a maioria dos pesquisadores que estudaram a autonímia não são, infelizmente, os que tratavam da metalinguagem", esta lingüista propunha "situar e descrever a autonímia em uma teoria da significação em que os signos são considerados intrinsecamente na relação entre significante e significado (1978:57)". No dizer de Tamba (2008:1): "Ela rompia, assim, de um lado, com o velho debate filosófico da referência, em que os signos são nomes de coisas e, de outro lado, com a questão das metalinguagens, colocada no quadro estreito de notação lógica dos anos de 1930”.

A seguir transcrevemos a lista dos estrangeirismos encontrados em nossa coleta:

account executive

advisor

after market

after-brake

after-market

agency fee

agribusiness

agricluster

agrobusiness

American Depositary
Receipt
antidumping
arbolito
asset
asset management
Automatic Teller
Machine
baby boomer
back stop facility

backed

backoffice

back-to-back

backup

balance scorecard

Balanced Scorecard

banker acceptance

benchmark

benchmarking

benefactor 
big business

big emerging markets

bigbusiness corporativo

black

blending

blind trust

blue chip

board

board feet

bond

bookbuilding

boom

box

Brady bond

brainstorm

brainstorming

Brazilian Depositary

Receipts

brent

bricolage

bridge loans

broker-dealer

building block

burn rate

business model

business plan

business to business

business to consumer

business-to-business

business-to-consumer

buy-back

C Bond

call center

candlestick

carpet bombing

carry over

carry trade

cash

cash flow

cash yield

catching up behavior

catching up inertia

C-Bond

chaebol

chairman

chinese wall

circuit break circuit breaker

Class

clearing

clearing house

clipping

cluster

coaching

co-brand

commercial paper

commitment

commodity

commodity linked bond

compliance

compliance officer

Conference Board

core business

core inflation

corralito

cost effective

counter vailing duties

coupon

crash

credit crunch

credit rating

credit record

crowding out

currency board

data room

data warehouse

day trade

day trader

deadline

dealer

default

défault

demurrage

dirty floating

disclosure

discount bonds

dividend yield

dividend yield médio

Domini 400 Social Index

dot.com

Dow Jones

Dow Jones Brazil Titans

20 ADR
Dow Jones Industrial

Average

Dow Jones Sustainability

down payment

downsizing

drawback

drawdown fee

dummy

dumping

duration

dutch disease

dynamic hedge

early warning

earmarked

e-business

e-commerce

Efficient Consumer

Response

El Niño financeiro

electronic cash

e-money

empowerment

Enhanced Surveillance

equity

establishment

eurobond

Euroland

euronote

ex-ante

excise taxes

exit bonds

export note

ex-post

expost-facto

exposure

exposure-Brasil

Extended Credit Facility

face-to-face

Facility Fee

factoring

farm bill

fast track

Federal Deposit Insurance

Corporation

federal funds rate

Federal Reserve

Federal Reserve Board 
ficker

firewall

first sell

Fitch Atlantic Ratings

flat tax

float

floating

forward pricing

franchising

free shop

free-on-board

fronting

full disclosure

full line

funding

funding loan

global bond

Global Environment

Facility

global player

Global System

Distribution

global trader

golden share

greenfield

grey market

hard bid

hard landing

hard money

head hunter

headhunting

heavy

hedge

hedge fund

hedged

hedger

hedging

high tech

hit

holding

home banking

home broker

home equity

home-banking

home-broker

hot money

in cash inflation targeting

Initial public offering

inputs

inside information

insider

insider trading

Institute of International

Finance

International Institute for

Economics

Internet

Internet Banking

investment grade

joint-venture

junk bond

just in time

keiretsu

laissez-faire

leading indicator

lean manufacturing

learning organization

lease

leasing

Least Developed

Countries

lender of last resort

leveraged buyout

lobby

loyal money

margin call

mark to market

market perform

market power

market share

market timing

market to market

marketweight

meltdown

middle market

$\operatorname{mix}$

mobile office

money chasing yield

multi-bubble syndrome

Nafta-plus

Nasdaq Composite

network strategy

newcomer no break

non paper

non tradeables

non-paper

offshoring

oil-shock

ombudsman

onça troy

online

open market

open sky

Organização do Comércio

Mundial

outplacement

outsourcing

over

overbooking

overgold

overnight

overshoot

overshooting

oversold

page-view

Pan European Forest

Certificate

panel

pass-through

patriotic rally

pay out

pension fund

performance bond

player

policy-based finance

pool

price maker

price taker

prime rate

private banking

private equity

private label

pro rata

project finance

Project Manager

public corporation

ranking

rating 


real estate investment
trust
recall
relending
research
resort
ringgit
road show
road-show
robber baron
royalty
samurai bond
scalper
Securities and Exchange
Commission
Securities Exchange
Commission
security
seed-money
segniorage
seignoriage
select fund
self-defeating
share of mind
site
slot
small caps
smart
smart card

smart money
Social Investment Forum
soft landing
soft money
special purpose company
spot
spot market
spread
spread over Treasury
stand by
standy-by
startup
stock guide
stock option
stock option
stop and go
supply-sider
swap
swing loans
tag along
take over
takeover
targeting inflation
tax free
T-bond
teasing
ticker
time-charter
timing

trade balance

trade finance

trade off

Trade Promotion

Authority

trader

trading

trading direcional

transfer pricing

traveller's cheque

trueque club

trueque megafair

trustee

underweight

unique visitor

Unit Labor Cost

upgrade

US Treasuries

valluation

value at risk

venture capital

webdesigner

webtrading

welfare

welfare state

wishful thinking

workaholic

yield

yuan 


\section{CONSIDERAÇÕES TEÓRICAS}

\subsection{Terminologia}

A terminologia é definida pela ISO 1087 como o estudo científico das noções e dos termos usados nas línguas de especialidade.

Já era praticada em tempos pré-históricos, pois desde sempre o homem sentiu a necessidade de nomear os objetos, coisas e processos do seu mundo. Segundo Cabré (1993:39), a primeira tendência está representada por três escolas — a de Viena, a de Praga e a de Moscou — pois somente no século XIX a terminologia foi identificada e reconhecida como ciência.

A terminologia clássica tem sua origem na Teoria Geral da Terminologia (TGT), fundada pelo engenheiro austríaco Eugen Wüster, principal representante da escola de Viena, e objetiva a precisão da linguagem e a univocidade dos termos; a TGT procura organizar sistemas conceituais, propondo a criação e normalização dos termos designativos dos conceitos estruturados em um sistema hierárquico. Segundo Krieger \& Maciel (2001:23), Wüster faz referência à relação da terminologia com todos os domínios da vida e sua conseqüente utilidade. Tal relação vincula-se às características maiores dos termos técnicocientíficos, os quais cumprem duas funções essenciais: a de representação e de transmissão dos conhecimentos especializados em todos os campos do saber científico e tecnológico.

A escola checa de terminologia surge como conseqüência dos trabalhos da lingüística funcional da escola de Praga; em conseqüência, ocupa-se quase que exclusivamente com a descrição estrutural e funcional das linguagens de especialidade, cuja caracterização depende do papel fundamental que a terminologia desempenha. As linguagens especializadas são consideradas um "estilo" profissional, que coexiste com outros estilos da linguagem, como o estético, o jornalístico e o conversacional. Esta escola, que concebe os termos como unidades que formam parte do estilo funcional profissional, desenrola-se como conseqüência da situação plurilíngüe do país e se interessa pela normalização das línguas e da terminologia. O 
trabalho terminológico checo está vinculado ao Instituto da Língua Checa, que faz parte da Academia de Ciências.

A escola soviética de terminologia, inspirada nos trabalhos de Kaplygin, Lotte e seus colaboradores, conhece as publicações de Wüster desde o momento em que estas aparecem, interessando-se esta escola sobretudo pela normalização de conceitos e termos no marco dos problemas que causam a situação de plurilingüismo da antiga União Soviética.

Essas três escolas de terminologia, que têm em comum o feito de moverem-se em uma perspectiva de base lingüística (consideram a terminologia como um meio de expressão e comunicação), são as que têm alimentado com suas contribuições a base teórica da terminologia e o corpus de princípios metodológicos que regula sua aplicação. (Cabré, 1993:40)

Nos anos 30, surge a primeira obra claramente teórica (Einführung in die Allgemeine Terminologielehre und terminologische Lexikographie), expondo a Teoria Geral da Terminologia, característica da Escola de Viena. Cabré (2000:21) lembra que a terminologia assume como elemento de base a intervenção consciente sobre o desenvolvimento das línguas, conforme o princípio que Wüster denominou "formação consciente da língua".

Wüster encara a terminologia como uma disciplina autônoma, descrita pela Teoria Geral da Terminologia (TGT), e definida como um campo próprio de relação entre as "ciências das coisas" e outras disciplinas, como a lingüística, a lógica, a ontologia e a informática. Para a TGT, a natureza do conceito, as relações conceituais, a relação termoconceito e a atribuição de termos aos conceitos ocupam um lugar-chave.

A terminologia resultou da necessidade prática de estabelecer uma comunicação que garantisse a univocidade. Para isso, os termos foram considerados como unidades extremamente fixas que indicam zonas claramente delimitadas de espaços conceituais. 
Para Opitz (1983:60, apud Meyer e Mackintosh, 2000:198), qualquer que seja a origem ou a maneira como os termos se formaram, estes buscam uma qualidade comum: um leque de significados estritamente definidos.

A terminologia, na acepção de Wüster, encarrega-se de estabelecer "aquilo que deve ser" e atua conscientemente, intervindo sobre os fatos materiais com o objetivo de direcionálos. A Lingüística, por sua vez, ocupa-se com "aquilo que existe", descrevendo os fenômenos produzidos e, por vezes, explicando sua razão de ser. A terminologia tornou-se, então, voluntariamente prescritiva, enquanto a Lingüística é necessariamente descritiva.

A partir da década de 90, porém, a TGT recebe críticas por desconsiderar as influências sócio-culturais nas linguagens de especialidade e por subestimar as situações pragmáticas de comunicação.

Surgem a socioterminologia e a Teoria Comunicativa da Terminologia (TCT), que se preocupam com a função comunicativa das linguagens de especialidade.

A socioterminologia é a disciplina que se ocupa da identificação e da categorização das variantes lingüísticas dos termos em diferentes tipos de situação de uso da língua. Para que o lingüista, especialista em terminologia, desenvolva seu trabalho de pesquisa, é preciso que leve em conta critérios básicos de variação terminológica no meio social, bem como critérios etnográficos, porque as comunicações entre membros da comunidade em estudo podem gerar termos diferentes para um mesmo conceito ou mais de um conceito para o mesmo termo. (Faulstich, 1995:1).

A orientação eminentemente normativa, reducionista e padronizadora da TGT é criticada e reivindica-se, então, uma terminologia descritiva que deve adequar-se a seu objeto natural de estudo e não fazer com que este se adapte às suas expectativas próprias ou suas necessidades práticas.

Em linhas gerais, a TCT, teoria proposta por Cabré (1999:120 e segs.), pretende dar conta dos termos como unidades únicas e, ao mesmo tempo, similares a outras unidades de 
comunicação, no âmbito de um esquema global de representação da realidade, admitindo a variação conceitual e denominativa e levando em conta a dimensão textual e discursiva dos termos. Para alcançar seus propósitos, esta teoria baseia-se em um conjunto de princípios e é descrita por uma série de fundamentos coerentes com seus pressupostos.

\section{Princípios da TCT}

Os princípios ou pressupostos nos quais se fundamenta a proposta de Cabré resumemse aos seguintes:

- A TCT não concebe a terminologia como uma matéria autônoma, mantendo seu caráter intrinsecamente interdisciplinar, e, defendendo a generalização, tenta explicá-la dentro de uma teoria da linguagem que se insere em uma teoria da comunicação e do conhecimento. Por sua vez, esta teoria da linguagem inclui aspectos propriamente lingüísticos, cognitivos e sociais.

- É necessário explicar as concomitâncias e diferenças entre o conhecimento geral e o especializado sem dissociá-las na competência do falante-especialista, mas conservando a idiossincrasia de cada um. Para tanto, é preciso pressupor que existem traços diferenciadores do conhecimento especializado, mas que este conhecimento não está interiorizado de forma independente na mente do falante.

- A TCT deve explicar a interdisciplinaridade das unidades terminológicas e dar conta da diversidade de visões que têm delas os diferentes especialistas implicados. Para isto, concebe as unidades terminológicas como unidades poliédricas integradas pelas três dimensões disciplinares que as descrevem. Os termos podem, assim, ser definidos conforme cada um desses três aspectos, o que explicaria a diversificação de acepções do termo segundo o tipo de especialista ou de especialidade que o define. A poliedricidade do termo, entretanto, não termina aqui; cada aspecto do poliedro se projeta, por sua vez, poliedricamente, em virtude de critérios de perspectiva ou de função distintos. Esta pluralidade complexa é uma consequiência do caráter multifuncional da terminologia como matéria e do caráter poliédrico e multidimensional do termo como unidade. 
- A TCT deve dar conta de como um conceito pode fazer parte da estrutura conceitual de diferentes disciplinas, conservando, alterando ou matizando suas características, explicando se se trata ou não do mesmo conceito e de como se produz esta circulação conceitual. Esta teoria parte, portanto, do pressuposto de que os termos não pertencem de maneira natural a nenhuma área, mas que são usados em uma certa área, sem que isto signifique que queiramos ignorar o fenômeno da aparição genuína de um termo em uma especialidade, nem que deixemos de reconhecer a transferência terminológica que se produz entre áreas especializadas ou entre o registro geral e o especializado. Simplesmente a anterioridade no tempo de aparição não parece pertinente para a teoria, ainda que possa ser útil para representar estruturalmente os traços semânticos que descrevem cada unidade.

- A TCT deve fornecer critérios para descrever as unidades denominativas monossêmicas ou polivalentes e definir os limites desta variação. Esta proposta assume, portanto, o caráter polissêmico das unidades léxicas e, nelas, a possível diversidade de módulos de traços especializados para uma mesma unidade, sem que isto suponha que não possam ocorrer unidades que só aparecem na comunicação geral e que, até o momento, nunca tenham adquirido caráter de termos, outras que só se usem como especializadas em uma área e outras, ainda, que possam aparecer em diferentes áreas e também na comunicação geral. Este pressuposto deixa a porta aberta para dar conta da banalização de unidades especializadas em um dado momento, da terminologização contínua de unidades gerais ou da migração constante de unidades especializadas de uma área para outra área (pluriterminologização), adquirindo traços associados a esta nova área.

- A TCT deve admitir a sinonímia como um fenômeno real dentro da comunicação especializada natural e fornecer critérios para estabelecer o valor diferente das unidades, se for este o caso. Ela parte da base de que a sinonímia na comunicação especializada é um fato real e quantitativamente dependente do nível de especialização de um discurso. Quanto mais especializado for um texto, maior será sua sistematicidade e menor seu grau de variação denominativa. A TCT supõe, também, que as unidades em relação de sinonímia podem ter um valor similar ou muito diferente, de acordo com os tipos de traços pragmáticos associados a cada variante. 
- Ela deverá levar em conta que as unidades terminológicas se dão de maneira natural no discurso e, conseqüentemente, têm uma projeção sintática para além de seus limites denominativos e podem variar em função do discurso. A descrição dos termos não pode se limitar à sua categoria, área temática, definição e equivalentes na mesma língua ou em outra língua, mas deve se estender para as condições de combinação no discurso, condições essas que incluem desde sua estrutura argumentativa, se possuem caráter predicativo, ou sua participação como argumentos em uma estrutura predicativa, até suas combinações semifixadas em fraseologismos.

- A TCT deve contemplar a própria variação do discurso e estabelecer as variáveis pertinentes que descrevam esta variação dentro da comunicação em geral e da comunicação especializada em particular. De acordo com esta idéia, ela assume, necessariamente, a diversificação discursiva em função da temática, a perspectiva a partir da qual se aborda um tema, o tipo de emissor, os destinatários, o nível de especialização, o grau de formalidade, o tipo de situação, o propósito, o tipo de discurso etc.

A distinção entre termo e palavra foi erigida em princípio e afirmada sobre o plano da significação, a significação da palavra dependendo em grande parte do contexto lingüístico e a significação do termo estando vinculada ao ambiente pragmático.

Para os terminólogos tradicionais, que seguem Wüster, existem diferenças suficientes entre termo e palavra para que possam ser apresentados como duas unidades independentes: os termos são unidades compostas de forma (a denominação) e conteúdo (o conceito) que coincidem com as palavras apenas aparentemente; o significado do termo, ou melhor, o conceito, seria preexistente à denominação. Como sugere Cabré (2000:23), a terminologia seria uma disciplina em busca de denominações potencialmente inexistentes a partir de noções existentes; a forma dos termos é controlada, ao passo que a forma das palavras não o é; as regras de formação dos termos utilizam estruturas diferentes das utilizadas na formação das palavras; os termos são autônomos em si mesmos, independentemente do contexto lingüístico em que surjam; os aspectos diacrônicos dos termos não são importantes para a terminologia clássica, que se interessa somente pela realização das unidades em sincronia. 
Em sua proposta de tentativa de modelização, Cabré (2000:26), após reconhecer e estabelecer a divergência entre a concepção de Wüster (TGT) e a sua própria, a Teoria Comunicativa da Terminologia (TCT), no que tange não só à separação entre termo e palavra, mas também a outros aspectos, envolvendo fundamentos teóricos, de metodologia e de suas aplicações, propõe uma busca de convergência entre as teorias. Para tanto, considera a palavra e o termo como unidades que se realizam naturalmente no discurso; são unidades de caráter lexical que fazem parte do dicionário mental de toda gramática e que integram o discurso através de estruturas superiores; pertencem a classes funcionais que coincidem com as palavras (com algumas restrições); por sua condição de caráter lexical, podem ser descritas por sua forma, seu conteúdo e seu modo de funcionamento no discurso; são mais ou menos sistemáticas em relação ao sistema geral da língua, que as recebe e também em relação ao domínio particular, no qual são colocadas, do ponto de vista nocional.

Esta sistematização implica que tais unidades seguem as mesmas regras morfológicas, lexicais e sintáticas do sistema lingüístico ao qual pertencem, e seu conteúdo pode ser descrito a partir das mesmas categorias que servem para descrever as palavras; consideradas no discurso real, apresentam uma variação denominativa; em seus usos discursivos, adquirem valores estilísticos e de conotação, ao mesmo tempo em que concretizam seu significado.

Pode-se concluir que, embora existam efetivamente elementos que diferenciem os dois tipos de unidade, eles não devem ser considerados como duas unidades diferentes, mas sim como realizações diferentes, no discurso, de um mesmo tipo de unidade.

A semântica é o primeiro aspecto diferenciador desses dois tipos de unidade. Não é o significado que diferencia as palavras dos termos, mas sim o processo de significação.

A pragmática representa o segundo elemento diferenciador entre as palavras e os termos. Do ponto de vista pragmático, os termos e as palavras são diferentes conforme seus usuários, conforme as situações em que são utilizados, conforme o assunto que abordam e conforme o tipo de discurso onde habitualmente ocorrem. 
A diferença entre os dois tipos de unidade e mesmo entre os dois usos de uma unidade depende também do enunciador do discurso, do controle do destinatário, ou, pelo menos, de uma classificação estrita que determina tipos diferentes de discurso segundo os destinatários que sempre têm por objetivo a aquisição de novos conhecimentos, da perspectiva segundo a qual se considera uma temática e da onipresença da referência acima das outras funções lingüísticas.

Diante desses argumentos, Cabré acredita existirem razões suficientes para tentar explicar as palavras e os termos a partir de uma mesma proposição: concebem-se as unidades como realizações em discurso de um mesmo tipo de unidade. As unidades lexicais, a priori, não serão palavras ou termos, mas, potencialmente, podem tornar-se termos ou não-termos e serem utilizadas em domínios diferentes.

A natureza do "termo" será ativada de acordo com o uso em um contexto e uma situação apropriados. Por isso, pode-se definir o termo como a unidade lexical ativada especialmente por condições de uso em um tipo de situação particular e, dessa forma, Cabré apresenta uma abordagem de modelização que considera tanto as palavras quanto os termos dentro de uma mesma unidade: a unidade lexical.

Para Sager (1990:2), a terminologia pode reivindicar o verdadeiro status interdisciplinar: é vital para o funcionamento de todas as ciências, ocupa-se das designações em todos os campos e está intimamente relacionada a um grande número de disciplinas específicas, como já assinalado por seu eminente protagonista, E. Wüster.

\subsection{Noções básicas - Conceito, Termo e Definição na Língua de Especialidade}

\section{Conceito}

Segundo a TGT, os conceitos são unidades de pensamento, que representam os objetos, os quais, por sua vez, são qualquer coisa que possa ser concebida, não importando se 
são concretos, abstratos, ou mesmo se existem ou não no mundo real (ISO 704, 2000:2). Os objetos, considerados em suas unidades, apresentam uma série de propriedades comuns, propriedades essas que são abstraídas como características. Na formação de conceitos, as características são agrupadas em conjunto. Chama-se compreensão o conjunto de características agrupadas para formar um conceito e extensão o conjunto de objetos que se enquadram no conceito. As características, por sua vez, podem ser essenciais, não-essenciais e distintivas. As características essenciais são aquelas necessárias para a compreensão de um conceito, dentro de um campo particular de conhecimento, de forma que a ausência de uma dessas características muda o conceito. As não-essenciais são aquelas cuja presença ou ausência não alteram o entendimento do conceito. Por fim, entre as características essenciais, consideram-se distintivas aquelas que são exclusivas de um conceito, isto é, que o diferenciam de outros no mesmo nível. É essa combinação única que situa o conceito numa rede de relações com características semelhantes e diferentes. As relações entre os conceitos determinam, pois, a estrutura do sistema conceitual (ISO 704, 2000:5).

A atribuição das características essencial, não-essencial ou distintiva depende do campo da especialidade em que atuamos e dos objetivos do trabalho terminológico que se realiza. Um mesmo objeto da realidade pode dar lugar a conceitos diferentes que pertencem a campos de especialidade também diferentes (Cabré, 1993:199)

\section{As relações entre os conceitos}

Os conceitos não são unidades isoladas, mas existem em um conjunto específico, relacionando-se uns aos outros, fazendo parte de um sistema lingüístico especializado. A área do conhecimento serve como moldura para o levantamento do campo conceitual, isto é, um conjunto de conceitos relacionados, mas não estruturados (ISO 704, 2000:5). Para se chegar ao sistema conceitual, deve-se examinar e comparar os conceitos do campo conceitual, utilizando-se das relações entre eles, que, segundo Felber (1987:101), discípulo de Wüster, são as seguintes:

- lógicas, ou seja, relações de subordinação e coordenação;

- ontológicas, isto é, relações partitivas, de sucessão, de material-produto;

- de efeito, ou seja, relações de causalidade, instrumento, filiação. 
As relações expressas nos sistemas conceituais podem ser representadas de diversas maneiras: por meio de árvores, diagramas, grades, listas etc. O levantamento do campo conceitual, isto é, do conjunto de conceitos relacionados é, pois, o ponto de partida para o estabelecimento do trabalho terminológico, que culminará com a compilação do vocabulário de uma área específica. Esse processo, segundo a ISO 704 (2000:14), inclui os seguintes passos:

- seleção do campo conceitual, isto é, dos conceitos e designações preliminares, levando-se em consideração a área do conhecimento, os usuários e suas necessidades;

- análise da compreensão a da extensão de cada conceito;

- construção do sistema conceitual, em que é determinada a posição dos conceitos, com base nas relações entre eles;

- formulação e avaliação das definições, com base nas relações conceituais;

- atribuição de designações aos conceitos.

Ao se compararem as noções existentes em várias línguas, verifica-se que algumas coincidem, mas existem graus diferentes de equivalência. Como a normalização, principalmente em âmbito internacional, é fundamental na TGT, pois ela visa facilitar a comunicação internacional, a construção de um sistema unificado de noções, que se aplique a várias línguas, é essencial para o trabalho de terminologia multilíngüe, segundo a proposta da TGT.

\section{As designações}

Em terminologia, as designações podem ser símbolos lingüísticos, termos, símbolos gráficos, matemáticos etc. As páginas a seguir restringir-se-ão à discussão das designações constituídas pelos termos.

Felber (1987:141) afirma que não se consegue perceber os conceitos apenas pelos sentidos. É necessário fazer uso de símbolos. O termo é um símbolo lingüístico, que pode constituir-se de uma palavra, grupo de palavra, letra, símbolo gráfico, abreviação, acrônimo. Designa um conceito, que, por sua vez, possui uma posição definida num sistema organizado dentro de determinada área do saber ou de um campo profissional. A relação entre conceito e 
denominação é estabelecida por deliberação dos especialistas, ao contrário do que acontece com as palavras da língua comum, em que essa união se dá, em geral, de maneira espontânea, o que faz com que seja comum a existência de dois ou mais significados para um único significante, ou, por outro lado, que ocorra mais de um significante relacionado a um mesmo significado. As palavras são, pois, potencialmente polissêmicas, mas tornam-se monossêmicas de acordo com o contexto em que ocorrem. É por isso que Felber (1987:141) diz que as palavras dependem do contexto, ao passo que os termos dependem do sistema conceitual ao qual pertencem. Entretanto, a criação terminológica obedece à estrutura fonológica, lexical e morfossintática de cada língua.

Enquanto a palavra é um signo do léxico de uma língua natural e é analisada como qualquer outro signo conforme seu significado e forma no sistema da língua a que pertence, o termo tem outra função, é a palavra em comunicação especializada. No dizer de Cabré (1993:169):

\footnotetext{
“Os termos, como as palavras do léxico geral, são ao mesmo tempo unidades de signo distintas e significativas, que se apresentam de forma natural no discurso especializado. Possuem uma vertente sistemática (formal, semântica e funcional), toda vez que são unidades de um código estabelecido, e manifestam, também, outra vertente pragmática, visto que são unidades usadas na comunicação especializada para designar os "objetos" de uma realidade préexistente".
}

Cabré (1993:172) lembra que embora a palavra termo sirva de maneira mais adequada para designar a unidade terminológica completa (o conjunto formado pela denominação e pelo conceito), também é utilizada como sinônimo de denominação.

\section{O termo}

As linguagens de especialidade são compostas por termos, os quais são definidos por Pavel e Nolet (2002:131) como: "palavra (termo simples), grupo de palavras (termo 
composto), sintagma, símbolo ou fórmula, os quais designam um conceito de uma área específica. São também chamados de unidade terminológica”. Ao conjunto de termos dá-se o nome de conjunto terminológico.

A norma ISO 1087 (1990:5) apresenta a seguinte definição de termo: “designação, por meio de uma unidade lingüística, de um conceito definido em uma língua de especialidade”. O termo é, portanto, uma unidade lingüística que contém um conteúdo específico de uma área e que é usada entre os especialistas desta área para sua comunicação interna, mas também é utilizada para a circulação, para a transmissão dos conhecimentos deste determinado campo do saber.

Segundo Cabré (1999), a definição de termo varia de acordo com o ponto de vista de três áreas distintas: a lingüística, a filosofia e o conjunto das diferentes disciplinas científicotécnicas. Para a primeira, é um subconjunto que está incluído no léxico do falante, forma parte de sua competência como falante / ouvinte ideal. Esta competência pode ser geral (língua geral) ou especializada (língua especializada), fazendo parte desta competência especializada a terminologia específica.

De acordo com a segunda área, os termos formam um conjunto de unidades cognitivas que representam o conhecimento especializado. São unidades de conhecimento e também de representação. E para a terceira e última, é o conjunto das unidades de expressão e comunicação que faz com que se transmita o conhecimento especializado.

Para a TGT, o termo deve estabelecer uma relação unívoca com seu respectivo conceito, isenta de conotações. A esse respeito, diz-nos Rastier (apud Alves, 1999:13):

"Na verdade, uma palavra torna-se um termo quando não tem mais passado e lhe é atribuída uma significação independente das variações conseqüentes das acepções e dos empregos contextuais."

Observa-se, assim, que pelo fato de um termo estabelecer uma relação unívoca com seu respectivo conceito, não deve manter relações significativas de sinonímia e de polissemia. 
Alves (1999:214) informa-nos que a essa postura rígida de terminologia normativa tem-se oposto o trabalho terminológico de cunho descritivo, em que a variação e a mudança lingüística são observadas e respeitadas. Nessa perspectiva, a relação unívoca entre um termo e um conceito, pregada pela Teoria Geral da Terminologia, deixa de ser um pressuposto necessário para garantir a eficácia da comunicação.

Desse modo, apesar das restrições dos teóricos da escola de Viena, a prática do trabalho terminológico tem demonstrado que, no âmbito de uma mesma língua de especialidade, o termo estabelece relações significativas com outros termos e pode estar sujeito à polissemia.

\section{A Definição}

A definição é um instrumento importante na análise da linguagem de especialidade.

É um elemento-chave na constituição e na veiculação do conhecimento especializado, tecnológico ou científico. Essa condição deve-se ao fato de esse tipo de enunciado expressar um segmento de relações de significação de uma dada área do saber, estabelecendo seus valores mais basilares.

A definição terminológica descreve, delimita e distingue os conceitos, implicando a demarcação de um limite. Busca definir o conceito, e não um significado, estabelecendo um jogo de conceito a conceito que determina as relações que os unem. A unidade de sentido visada na definição terminológica é o conceito ou noção, que difere substancialmente do significado. O significado mantém um laço de indissociabilidade com o significante. $\mathrm{O}$ conceito, ao contrário, é uma unidade muito mais livre (Desmet, 1990, apud Lara, 2004) que se delimita no domínio.

A definição é a descrição de um conceito por meio de outros conceitos conhecidos, na maior parte das vezes sob forma de palavras e termos. Isso determina a posição deste conceito em um sistema de outros conceitos relacionados. Uma explicação é uma descrição de um conceito sem considerar sua posição no sistema de conceitos. Em uma definição, os conceitos 
podem ser relacionados por: 1- determinação, 2- conjunção, 3- disjunção e 4- integração. Dependendo da ligação, podem ser definições por compreensão (determinação) ou definição por extensão (conjunção, disjunção, integração) (Felber, 1987:160).

Krieger \& Finatto (2004:92) afirmam que há vários tipos de enunciados definitórios. A definição terminológica é reconhecida como aquela que mais se ocupa de termos técnicocientíficos. A definição lexicográfica, por sua vez, é compreendida como aquela que mais se ocupa de palavras. Em outra perspectiva, a definição lógica estabelece um valor proposicional de verdade, enquanto as definições explicativas ou enciclopédicas contêm informações variadas sobre um dado objeto da realidade. Uma classificação por tipos definitórios, vale sublinhar, é estabelecida em função de algumas características que são predominantes ou mais salientes numa dada formulação. Portanto, há sobreposições entre um tipo e outro, de tal modo que uma definição lexicográfica, por exemplo, poderá apresentar elementos ou características de um padrão que se reconheça como enciclopédico.

\subsection{Língua Geral / Língua de Especialidade}

A diferença entre língua geral e de especialidade é mais uma diferença de grau do que de natureza. Para Krieger e Finatto (2004:198), não há uma fronteira fixa entre léxico especializado e léxico comum, nem entre linguagem comum e linguagem especializada, pois os valores semânticos e conceituais que envolvem algumas unidades são tanto instáveis quanto dependem de sua inserção em contextos e co-textos, além de dependerem do perfil das áreas de conhecimento em que são usados.

Uma língua particular constitui-se por um conjunto diverso de subcódigos que o falante utiliza em função de suas modalidades dialetais e que seleciona em função de suas necessidades expressivas e das características de cada situação comunicativa. Entretanto, além de toda esta complicada diversidade, toda língua particular possui um conjunto de unidades e regras que é conhecido por todos os seus falantes.

O conjunto de regras, unidades e restrições que formam parte do conhecimento da maioria dos falantes de uma língua constitui a chamada língua comum ou geral, que 
representa um subconjunto da língua entendida em sentido global. As unidades da língua comum são utilizadas em situações que podem se classificar como "não marcadas".

Contudo, falamos de linguagem de especialidade (ou de linguagens especializadas) para fazer referência a um conjunto de subcódigos — parcialmente coincidentes com o subcódigo da língua comum - caracterizados por algumas peculiaridades "especiais", isto é, próprias e específicas de cada um deles, as quais podem ser a temática, o tipo de interlocutores, a situação comunicativa, a intenção do falante, o meio em que se produz um intercâmbio comunicativo, o tipo de intercâmbio etc. As situações em que se utilizam as linguagens de especialidade podem-se considerar, neste sentido, "marcadas".

A língua geral (la langue toute entière, nos termos de Kocourek), que compreende tanto as variedades marcadas como as não-marcadas, pode ser considerada como um conjunto de conjuntos, sobrepostos e interrelacionados a partir de muitos pontos de vista. A ligação comum a todos os conjuntos é a língua comum. Cada um dos subconjuntos pode ser uma língua especializada. Essa é, em resumo, segundo Cabré (1993:129), a aproximação mais lingüística às línguas de especialidade.

Toda área de especialidade necessita de uma linguagem particular que seja do conhecimento dos profissionais ligados a ela. Esta necessidade dá-se, pois, em uma comunicação especializada, não podendo haver ruídos, uma vez que estes prejudicam a comunicação precisa. Segundo Krieger, "tal precisão é uma condição necessária a um eficiente intercâmbio comunicacional entre diferentes ramos do conhecimento" (Krieger, 2000:210).

“Após reflexões feitas pelos terminólogos nos últimos anos, convencionou-se chamar as línguas de especialidade de linguagem de especialidade, pois, segundo a tradição lingüística, a linguagem é a língua em uso. No entanto, uma vez que o termo língua já estava consagrado, ainda é usado com muita freqüência hoje pelos especialistas nos seus trabalhos (Cabré ,2004, apud Santos, 2006)”. 


\subsubsection{Economia e Língua de Especialidade}

À medida que a sociedade se desenvolve e novas abordagens em muitos campos de estudo surgem, também se elabora uma linguagem para expressar diferentes categorias do conhecimento. As novas variantes lingüísticas revelam a completude de recursos de que a língua dispõe para preencher as necessidades específicas de cada área. Cada área dispõe de um jargão.

O dicionário Aurélio assim define jargão: "linguagem peculiar àqueles que exercem a mesma profissão ou arte".

Para o professor Possenti, da Unicamp, a crítica aos jargões é romântica, uma espécie de utopia pré-Babel. "Não dá para falar de lingüística sem usar jargão. Um aspecto constitutivo de qualquer saber é uma linguagem própria", afirma Possenti. Segundo ele, é ingenuidade tentar combater as divisões sociais começando pela língua. "O problema é a mídia ouvir o economista sobre a alta de juros, em vez de ouvir o feirante", argumenta. Economista usa jargão, feirante usa gíria, mas a diferença entre os dois fenômenos lingüísticos é menos científica e mais baseada no status, segundo ele. "Na verdade, é uma distinção social. Jargão é a gíria dos bem-postos, e gíria é o jargão dos despossuídos." (Helvécia, 2003).

Os grupos sociais e profissionais têm uma tendência de criarem sua própria linguagem. $\mathrm{O}$ mesmo ocorre com a Economia. $\mathrm{O}$ economês constitui-se na linguagem própria da área da Economia, atividade que, como outras, exige linguagem própria, embora freqüentemente se enfatize o aspecto depreciativo, obscuro e corporativista desta linguagem.

Câmara Jr. (1978:127-128) assim se expressa:

"Há gírias em classes e profissões não só populares, mas também cultas, sem qualquer intenção de chiste e petulância, que comumente caracteriza as primeiras; mas em todas há uma atitude estilística. Quando se trata de mero vocabulário técnico, sem essa atitude, tem-se 
a LÍNGUA ESPECIAL, como a dos médicos, baseada em helenismos técnicos".

Alves (2001:175) lembra-nos que

“o economês é pleno de metáforas. O emprego figurado, presente na linguagem das ciências e das técnicas, como também nos sistemas semióticos utilizados nas ciências, não se mostra incompatível com a busca de precisão que caracteriza as terminologias, enfatiza Kocourek, em seu estudo sobre a língua francesa empregada nos textos técnicocientíficos (1991:167). Assim, pelo procedimento da transferência semântica - que contribui, juntamente com as criações formais (derivação, composição, formações sintagmáticas e por siglas) e os empréstimos uma das possibilidades de criação neológica (cf. Guilbert, 1975; Boulanger, 1979) -, os economistas vão atribuindo a palavras da língua geral e a termos de diferentes áreas técnicas um outro significado e criando, assim, termos do domínio da economia".

A autora (2001:178) diz ainda:

“[...] a introdução de termos do economês nos dicionários de língua pode indicar que esses termos não mais são usados exclusivamente por economistas e constituem unidades lexicais de interesse dos demais usuários da língua. Termos como âncora monetária, crescimento, gatilho salarial, hot money, moeda podre e tigre asiático, não inseridos na edição de 1986 do dicionário de Ferreira, já estão registrados na terceira edição da obra (1999), e correspondem, assim, a metáforas já mortas, ou a expressões metafóricas de interesse do público geral.”

Ou seja, paulatinamente, os termos técnicos vão penetrando na língua, agregando-se ao léxico. 
"A inserção desses termos do economês em uma obra lexicográfica permite-nos observar que, se muitas das criações do jargão da Economia são efêmeras, algumas se integram à língua",

o que permite à autora concluir com as palavras de Preti:

"Os jargões decorrem, pois, do registro social que certas atividades alcançam em determinadas épocas, fazendo com que seu vocabulário técnico, quase sempre muito restrito, conhecido por uma minoria, alcance também prestígio social. Justamente aqueles que desejam usufruir desse prestígio é que acabam por banalizar o vocabulário técnico profissional.” (Alves, 2001:179). 


\section{A CRIATIVIDADE LEXICAL}

As transformações sociais e humanas que ocorrem, inexoravelmente, ao longo da história, geram a necessidade de nomear os processos que surgem, os objetos criados, as técnicas e conhecimentos decorrentes das ciências e da tecnologia. Assim se expressa Coseriu (1980:125):

"Uma língua não é apenas aquilo que já está feito por meio de sua técnica, mas é também aquilo que, mediante esta mesma técnica, se pode fazer; não é somente passado e presente, mas possui uma dimensão de futuro."

A criatividade humana insere-se na tendência e necessidade que o ser humano tem de responder às suas inquietações internas e aos desafios e mistérios do mundo externo: ele precisa criar para sobreviver. A criatividade lingüística faz parte dessa criatividade mais genérica, inerente ao indivíduo. Na realidade,

“a mutabilidade lingüística, ao nível do léxico, verificável à medida que signos são criados ou sofrem modificações em seus significados, é um processo inerente à língua e não uma ameaça à sua continuidade" (Barbosa, 1998:33).

A Economia, área em permanente ebulição, plena de atividades internacionais, reguladora de atividade vital para os indivíduos e para a coletividade, acaba por ser palco de grande dinamismo lexical. Preti (1998:119) afirma, a respeito dessa ebulição lexical:

"O léxico [em comparação com a sintaxe] melhor se presta a mostrar as transformações sociais de uma comunidade e se constitui na parte menos conservadora de uma língua. Vocábulos que surgem e desaparecem, num processo contínuo e natural de neologia e obsolescência, são o reflexo mais perfeito das mudanças sociais". 


\subsection{Neologia}

A neologia é o estudo dos fenômenos novos que surgem nas línguas. No decorrer do tempo, o léxico de uma língua se renova com a criação de novas unidades lexicais. As línguas se renovam permanentemente, mantendo sua vitalidade com a inclusão de novas palavras e com a exclusão de outras que são postas de lado. As gramáticas que consideram (ou consideravam) a língua como produto acabado encaravam o neologismo como erro, como vício de linguagem, assim como o barbarismo, o arcaísmo, o provincianismo.

$\mathrm{Na}$ verdade, uma língua não consegue manter-se viva se não evolui, mas, segundo Dubuc (1978:65), esta evolução não é anárquica: ela se depreende de linhas de força, de tendências que se tornam conhecidas quando se julga ou se cria uma palavra nova. Assim também dispõe Rey (1995:66):
"Embora praticamente todas as combinações possíveis autorizadas pela gramática sejam aceitas pelo léxico, a admissão final é basicamente determinada pelas restrições sócio-culturais."

A caracterização de um termo como neológico não é tarefa fácil, diz Cabré (1993:445), se não se fixam, previamente, alguns pontos de referência que sempre são em certa medida arbitrários. Para determinar o caráter neológico de uma unidade léxica, foram propostos parâmetros distintos:

a) A diacronia: uma unidade é neológica se apareceu em um período recente;

b) A lexicografia: uma unidade é neológica se não aparece nos dicionários;

c) A instabilidade sistemática: uma unidade é neológica se apresenta sinais de instabilidade formal (morfológicos, gráficos e fonéticos) ou semântica.

1 Tradução nossa, como a maioria dos textos estrangeiros consultados no original. 
d) A psicologia: uma unidade é neológica se os falantes a percebem como uma nova unidade.

De maneira geral, os estudiosos da neologia levam em conta o critério lexicográfico, segundo o qual uma unidade é neológica se não estiver inserida em um conjunto de dicionários, o corpus de exclusão.

A criação neológica resulta, em grande parte, de um ato espontâneo, ensina-nos Alves (2003:273). Desse modo, o falante, de maneira geralmente inconsciente, vai associando radicais a afixos, compondo novas unidades lexicais a partir de outras já empregadas e atribuindo novos sentidos a unidades já integradas ao acervo lexical de uma língua.

Essa espontaneidade não impede, no entanto, que o falante interprete suas eventuais criações e, sobre elas, teça comentários. Essa auto-interpretação - termo criado por Sablayrolles (2000:197, apud Alves, 2003: 273) para referir-se às reações do falante criador em relação aos neologismos por ele introduzidos - é mais evidente em situações de interlocução, em que o locutor se questiona sobre a unidade lexical por ele enunciada, que ele sente como nova, e sobre seu impacto sobre o interlocutor.

Para os lexicólogos clássicos, como Guilbert (1975) e Rondeau (1984), a neologia trata do estudo dos fenômenos lingüísticos que surgem em um determinado momento da evolução de uma língua viva. Estes fenômenos podem manifestar-se em qualquer dos níveis descritivos de uma língua: a fonética, a fonologia, a morfologia, a sintaxe e o léxico.

Guilbert (1975:59) propõe quatro tipos de neologia: a neologia fonológica, a sintagmática, a semântica e a neologia formada por empréstimo. A primeira consiste na formação da substância do significado e na sua transcrição. A segunda engloba todos os modos de formação que implicam a combinação dos elementos diferentes; é de caráter morfossintático e reúne, também, todas as formas de derivação e composição.

A terceira, a neologia semântica, consiste no surgimento de uma significação nova para um mesmo significante. Corresponde a uma criatividade que muda as regras pela 
transgressão de um traço de categorização ou seleção — uma variedade seria a neologia de conversão que muda a classe gramatical da palavra, por elipse, do termo semanticamente mais pobre, ao qual se está associado: um caro automóvel. Outra variedade neutraliza um traço contextual de seleção do termo.

Para o autor, a neologia semântica diferencia-se das outras formas de neologia, pelo fato de a substância significante utilizada como base preexistente no léxico não sofrer nenhuma modificação morfológica, nem novas combinações intralexemáticas de elementos, mas passar a exercer a função de nova unidade de significação.

E a quarta, neologia formada por empréstimo, define os diferentes aspectos do empréstimo. Para este autor, (1975:97), há três critérios por meio dos quais se deve avaliar se uma unidade lexical está, ou não, em fase de integração a uma determinada língua. São eles: fonológico, morfossintático e semântico. Segundo o critério fonológico, um termo estrangeiro começa a fazer parte de uma língua à medida que se integra fonologicamente a ele. Do ponto de vista morfossintático, a partir do momento em que o termo serve de base a uma derivação, de acordo com o sistema morfossintático da língua que o acolheu; do ponto de vista semântico, quando o termo assume o papel de significante de vários significados, testemunhando sua inserção definitiva no sistema lexical na língua de chegada.

Guilbert (1975), estudando a criatividade lingüística, chegou às seguintes conclusões, assim resumidas:

1) Os progressos do conhecimento científico e técnico se traduzem necessariamente por um movimento do léxico que não se realiza apenas pela introdução de um conjunto homogêneo de palavras novas. Sua gênese apresenta o aspecto diacrônico.

2) $\mathrm{O}$ conjunto lexical novamente construído é ligado à realidade extralingüística e põe em evidência uma dupla estrutura: séries lexicais de ordem semântica pela transferência do vocabulário de uma técnica a outra e séries lexicais de ordem morfológica, formadas a partir de uma mesma base. 
3) A neologia sintagmática que surge em uma designação única é, pois, semanticamente nova. É uma lexia completa, formada de várias palavras. A relação das palavras com suas paráfrases e perífrases de definição e a lexia complexa são desse tipo e conduzem à hipótese de uma ligação entre léxico e sintaxe. Ex: autogestão e autonomia de gestão.

Alves (1994:11-82), com base em Guilbert, descreve os processos de formação neológica, a saber, neologismos 1) fonológicos; 2) sintáticos; 3) por conversão ou derivação imprópria; 4) semânticos; 5) "outros processos menos produtivos", tais como truncação, a palavra-valise, a reduplicação e a derivação regressiva; e, finalmente, 6) os neologismos formados por empréstimos.

Falamos de neologia léxica, pondera Cabré (1993:444), para referirmo-nos ao aparecimento de palavras ou neologismos léxicos. Neste sentido, a neologia compreende todas aquelas unidades lexemáticas com capacidade referencial que podem constituir uma entrada de dicionário, sejam unidades simples, sejam formações sintagmáticas.

Esta definição tradicional de neologia, que cobre somente os processos lingüísticos de formação de palavras novas, revela-se atualmente pobre para descrever o amplo movimento que surgiu em torno das novidades lingüísticas. A vertente lingüística da neologia é só uma das aproximações possíveis ao tema, entre toda uma série de enfoques que situam a neologia num nível tríplice: lingüístico, cultural e político.

Do ponto de vista da lexicografia, diz Lerat (1995:131):

“A neologia nada mais é do que o registro de novas palavras, sob a pressão das necessidades de denominação, de expressão e de comunicação. Em outras palavras, é um programa simples e claro: a atualização dos dicionários, seguindo tanto os caprichos do uso como as inovações importantes, após a verificação da ausência de candidatos nos dicionários existentes (o corpus de exclusão) e representando uma aposta sobre sua longevidade pressuposta. As 
apostas não são negligenciáveis: comerciais (a neologia é um importante argumento de venda para o mercado de dicionários de volume único), tradutológicas (para os textos recentes) etc.”

\subsubsection{Neologia nas Línguas de Especialidade}

O neologismo desempenha função relevante não apenas na língua geral, mas também nas línguas de especialidade. As unidades neológicas respondem à necessidade de nomear novas realidades (objetos, conceitos, processos) anteriormente inexistentes.

Segundo Alves (1996:40), o desenvolvimento dos trabalhos terminológicos, quer sejam eles considerados de um ponto de vista apenas descritivo, ou também de uma perspectiva normalizadora, que incentiva a criação de termos, redimensionam as características do fenômeno neológico. O neologismo passa assim a ter uma função relevante não somente na língua geral. Nas línguas de especialidade é definido pela Norma ISO 1087 (que trata do vocabulário da terminologia), como “termo de criação recente ou emprestado há pouco tempo de uma língua estrangeira ou de uma outra área do conhecimento.”

Rondeau (1984:129-130) assinala a especificidade do neologismo terminológico, distinguindo-o do neologismo lexical da língua comum da mesma forma como o termo se distingue do neologismo lexical da palavra, propondo a denominação de neonímia para a noção de neologia terminológica. O neônimo, diz ele, compartilha com o termo características específicas, especialmente ${ }^{2}$ :

1. a univocidade, ou seja a relação única e reversível entre significante e significado, ou entre denominação e noção, que se estabelece desde a origem entre uma forma lingüística da linguagem de especialidade e a noção que ela representa;

\footnotetext{
${ }^{2}$ Algumas dessas considerações não são mais aceitas por terminólogos contemporâneos.
} 
2. a monorreferencialidade, ou seja, o fato de que um significante terminológico, mesmo complexo, representa na mente de um especialista da área um conjunto nocional único;

3. o pertencimento a uma área ou a uma rede nocional. Esta característica distingue essencialmente o neônimo do neologismo;

4. sua justificação. O neônimo é, de fato, criado sempre para responder a uma necessidade de comunicação (seja na língua de origem, seja na língua-alvo);

5. do ponto de vista da forma, o neônimo é freqüentemente do tipo sintagmático e, portanto, mais longo;

6. o neônimo possui uma estabilidade maior que o neologismo; além disso, conforme sua frequiência de utilização, a duração de seu estado neológico é em geral mais reduzida, pois passa a integrar o uso;

7. o neônimo recorre a séries afixais cujos valores semânticos são fixos e tem freqüentemente um caráter internacional.

Rondeau (1984:130) classifica os modos de formação neonímica em três tipos: morfológico, morfossemântico e morfossintático.

Morfológico: o mais importante e, sem dúvida, o mais produtivo, é representado pela derivação a partir de bases variadas, às quais se juntam as séries afixais bem caracterizadas. $\mathrm{O}$ segundo modo de formação morfológica é a apócope, que consiste na redução no cumprimento de uma forma lingüística que elimina sílabas, geralmente à direita. É o caso conhecido de cinematógrafo $\rightarrow$ cinema $\rightarrow$ cine.

É interessante notar, diz o autor, em relação a essas bases, que, de um lado, não se sente mais a necessidade, como no século XIX, de se conservar uma homogeneidade lingüística nos compostos, no sentido de que se pode muito bem encontrar uma base grega e 
uma base latina em um mesmo termo e que, por outro lado, tem-se a tendência a considerar estas bases como fazendo parte do fundo lingüístico das línguas modernas, pelo menos indoeuropéias.

Morfossintático: mais importante e produtivo é o do grupo sintagmático que pode ser encarado sob dois aspectos: em relação à sua forma e em relação aos elementos que o compõem.

A siglação participa do mesmo fenômeno, pois constitui um modo de abreviar os agrupamentos sintagmáticos. No caso da siglação ocorre dupla criação neonímica. O segundo modo de formação morfossintática é o da redução, que consiste em combinar uma parte dos elementos de dois ou mais termos. Também a mudança de categoria gramatical (adjetivo $\rightarrow$ substantivo, nome próprio $\rightarrow$ nome comum) se inclui neste modo de formação.

Morfossemântico: Aqui se incluem o decalque e o empréstimo. Embora não muito freqüente e até objeto de restrições e até mesmo de hostilidade, o decalque, ou seja, a tradução literal de palavra a palavra de um termo de uma língua para outra, ainda permanece como o modo de formação neonímica à qual se recorre. O empréstimo é o modo mais freqüentemente utilizado, sendo que Rondeau distingue dois tipos: o empréstimo interno, no interior de uma mesma língua, e o empréstimo externo, o que implica a passagem de um termo para outra língua.

Nas línguas de especialidade, o processo de neologia tem se revelado bastante produtivo. A área da Economia, especialmente, parece ser prolífica na formação de novas palavras.

\subsection{Estrangeirismos}

O estrangeirismo consiste no emprego, em uma determinada língua, de elementos provenientes de outras línguas. Os estrangeirismos ocorrem com freqüência no contato entre comunidades lingüísticas. O tema dos estrangeirismos tem a capacidade de suscitar paixões, colocando "puristas" contra "globalizados". Freqüentemente, as atitudes manifestadas nada 
têm a ver com as questões linguiísticas propriamente ditas, referindo-se a interesses políticos e ideológicos.

Esse fenômeno de mudança lingüística, provavelmente, atrai mais a atenção pública do que qualquer outra questão lingüística (Crystal, 1997:4 e segs). Há uma crença arraigada de que mudança significa deterioração e declínio. As pessoas de mais idade observam a linguagem coloquial dos jovens e concluem que os padrões decaíram de maneira significativa. A "culpa" é atribuída aos mais diversos segmentos, às escolas que têm mudado seus padrões de linguagem, aos imigrantes (internos e externos), às classes baixas, à mídia que quando se desvia do padrão tradicional propicia um foco para o ataque dos conservadores e puristas zelosos da integridade da língua. Em cada época acredita-se que a língua contemporânea está no ápice de sua decadência, mas tal crença é na realidade partilhada por gerações que se sucedem. Na verdade, algumas questões de uso percorrem várias gerações sem que, no entanto, a língua seja severamente afetada.

Há casos em que as mudanças lingüísticas podem ocasionar problemas de nãointeligibilidade, ambigüidade e distinção de classes - situações essas que poderiam ser objeto de eventuais considerações da lingüística. Mas, via de regra, as partes da língua que mudam ou estão em mudança, a cada momento, são diminutas em comparação com as enormes áreas da língua que permanecem invariadas. De maneira geral, a língua muda porque a sociedade muda. Parar ou controlar uma das variáveis exige que se pare e se controle a outra variável tarefa essa de resultado duvidoso.

Segundo o neogramático Hermann Paul (1983:412, apud Manzolillo 2007:1), “a palavra de origem estrangeira só gradualmente se torna habitual”. Essa idéia, já antiga, ainda hoje é bastante difundida, razão pela qual grande parte dos autores dedicados ao assunto do empréstimo lingüístico propõem uma diferenciação entre empréstimo propriamente dito e estrangeirismo. As designações xenismo e peregrinismo também são usadas. ${ }^{3}$

${ }^{3}$ Carvalho (2000:196) define peregrinismo como a "primeira fase de aceitação" da unidade lexical alógena e xenismo como "o termo importado [que] permanece na grafia original (mesmo muito usado)”. (Manzolillo, 2007:02). 
Em linhas gerais, o primeiro conceito refere-se à unidades lexicais de alguma forma já integradas ao novo ambiente, enquanto o segundo diz respeito àquelas francamente alienígenas, ainda não incorporadas ao léxico da língua recebedora. Na prática, tal divisão revela-se problemática em algumas situações, pois variados e subjetivos são os critérios passíveis de utilização no seu estabelecimento.

Como se sabe, durante muito tempo, prossegue Manzolillo, a tradição fonológicogramatical luso-brasileira identificou o termo estrangeiro como um vício de linguagem: tratava-se de fator de empobrecimento lingüístico. Essa noção, de certa maneira, resiste até hoje, como o trecho a seguir é capaz de comprovar. Nele, estrangeirismo é assim definido: "Palavra ou expressão de origem cujo uso é um dos erros contra a vernaculidade da nossa língua, e só poderá ser aceito se não existir na língua portuguesa um vocábulo que traduza essa mesma idéia" - Rocha (1997). O desenvolvimento dos estudos lingüísticos, no entanto, colocou o estrangeirismo em outro patamar, freqüentemente em confronto com o empréstimo.

Biderman (1978:162-163) cita três tipos de estrangeirismos: decalque - como sendo uma versão literal do lexema modelo da língua originária; adaptação da forma estrangeira à fonética e ortografia brasileira - caso que ocorre quando o estrangeirismo já foi adotado há muito tempo por nossa cultura e a incorporação do vocábulo com a sua grafia e fonética originais. Cita os seguintes exemplos, respectivamente: supermercado; coquetel (cocktail), e gangster.

Bechara (2001:599), embora também faça menção às duas categorias, afirma que:

"De modo geral, os estrangeirismos léxicos repartem-se em dois grupos: os que se assimilam de tal maneira à língua que os recebe que só são identificados como empréstimos pelas pessoas que lhes conhecem a história [...]; mas há os que facilmente mostram não ser prata da casa, e se apresentam na vestimenta estrangeira [...] ou se mascaram de vernáculos [...]. O termo empréstimo abarca essas duas noções e se aplica tanto aos estrangeirismos léxicos quanto aos sintáticos e semânticos.” 
Segundo Alves (1994:72-73), denomina-se estrangeirismo a primeira etapa por que passa a palavra oriunda de outra língua. Nesse nível, ela é sentida como externa à língua importadora. $\mathrm{O}$ estrangeirismo costuma ser empregado em contextos relativos a uma cultura alienígena, externa à língua enfocada. Nesses casos, imprime à mensagem a "cor local" do país ou da região estrangeira a que faz referência.

Sucede o neologismo por empréstimo quando o termo advindo de uma outra língua passa a ser usado freqüentemente pelos usuários da língua importadora. $\mathrm{O}$ emprego freqüente de um determinado termo estrangeiro é um dos critérios que fazem com que esse estrangeirismo evolua para um empréstimo. Se, ao ser importada, uma palavra passa a ser muito veiculada pela imprensa e muito utilizada nos atos de fala, o falante da língua importadora passa a não mais senti-la como externa à sua língua, começando a vê-la como palavra integrante do seu acervo lexical.

Destacamos que, em nosso trabalho, classificaremos como estrangeirismos todas as unidades que ainda não sofreram adaptação ao português, ou seja, são registradas em sua forma original, e empréstimos lingüísticos aquelas que já estão adaptadas ao nosso sistema, seja por adaptação fonológica, morfológica ou semântica, não causando, assim, esse estranhamento relatado pela autora.

Mantemos, assim, a distinção estabelecida por Guilbert (1975) entre estrangeirismo e empréstimo. Esse estudioso da neologia classifica como estrangeirismo a unidade lexical sentida como externa à língua. $O$ estrangeirismo que está instalado é um verdadeiro neologismo e somente se tornará um empréstimo no momento em que não for mais percebido como externo ao idioma.

\subsection{Empréstimos}

O acervo lexical do português tem sido enriquecido através dos tempos por meio de processos vernáculos (derivação, composição, truncação, transferência semântica) e por empréstimos de outros sistemas lingüísticos. 
Quando há relação entre duas línguas, a proximidade ou coexistência têm a tendência de modelar o léxico de uma e de outra língua.

O empréstimo, em suas diversas matizes, diz Aubert (2003:2), enriquece as línguas ou as desfigura, a depender do ponto de vista cultural assumido e da correlação - momentânea ou duradoura - das forças de dominação e de resistência em confronto e a depender, ainda, do recorte sincrônico assumido. O destino dos empréstimos, em qualquer momento dado, é sempre incerto: ou desaparecem, substituídos por soluções vernaculares; ou passam por transformações, quer de significante, quer de significado, e, deste modo, deixam de lado seu caráter de empréstimo para tornarem-se parte integrante do universo cultural que os acolheu. Já vernacularizados, podem vir a tornar-se novos empréstimos, agora em terceiras línguas... É pela tradução que o estrangeirismo, de qualquer tipo, via de regra faz a sua primeira incursão. A questão do empréstimo assume, pois, aspectos lingüísticos, sociolingüísticos, culturais, sincrônicos e diacrônicos, oferecendo, pois, um amplo campo de pesquisa e de reflexão.

Tão importante é a parte recebida por empréstimo que A. Rosetti (apud Alves, 1988:1), chega a afirmar que é "fato pacifico que não existe língua inteiramente isenta de mistura com elementos de outras línguas".

A tendência à adoção de empréstimos manifestada em todas as línguas do mundo, em maior ou menor intensidade, pode ser explicada pela força de intercurso, assim denominada por Saussure, que percebia na linguagem a ação de duas forças opostas: o espírito de campanário e a força de intercurso. O espírito de campanário faz com que uma comunidade lingüística seja fiel às tradições e evite inovações. A força de intercurso obriga os homens a interagirem, favorecendo a adoção das inovações e propagando-as. No caso do empréstimo, é a força de intercurso a responsável por sua disseminação numa área maior. (Carvalho, 1989:35).

Segundo Alves (1984 (2):120), apoiando-se em Guilbert (1975), o termo estrangeiro percorre uma fase neológica, a qual corresponde à sua instalação no sistema de uma língua: morfossintaticamente, pode originar derivados, compostos, vocabulários híbridos e, geralmente, se integra ao sistema flexional de número e gênero da língua receptora. Do ponto 
de vista fonológico; começa a fazer parte do léxico de uma língua à medida que se integra fonologicamente a ele, e semanticamente, a instalação do termo estrangeiro ocorre quando tal elemento introduzido na língua receptora, com um único significado, torna-se polissêmico.

As palavras de origem latina, usadas no português, são naturalmente justificadas. O mesmo ocorre com palavras de origem grega, na medida em que vocábulos gregos também se encontram presentes no léxico latino.

Segundo Câmara Jr. (1974:158)

“os empréstimos abundantes e francos são os de vocábulos ou 'lexicais', onde um radical estrangeiro se adapta à fonologia e à estruturação morfológica da língua importadora”.

Além dos estrangeirismos, nota-se que alguns elementos constituem pseudoestrangeirismos, ou seja, apresentam um aspecto externo ao vernáculo, podendo ser formados por uma unidade vernácula e outra de idioma estrangeiro, ou até mesmo por unidades lexicais compostas por elementos estrangeiros, mas inexistentes na própria língua de origem.

Os pseudo-estrangeirismos podem ser constituídos por uma unidade vernácula e uma inglesa. $\mathrm{O}$ falso estrangeirismo pode também se caracterizar por um sufixo não-existente na língua portuguesa ou empregado exclusivamente no discurso publicitário.

O falso estrangeirismo pode ser constituído por uma unidade lexical composta com elementos ingleses, porém inexistentes na língua inglesa.

\subsubsection{Empréstimos nas Línguas de Especialidade}

A fase neológica é representada pela implantação da unidade lexical em que há freqüência de ocorrências e que, muitas vezes, registra um processo de adaptação ortográfica, fonológica ou morfológica. O empréstimo constitui-se na unidade lexical já difundida e integrada ao acervo lexical da língua. 
Nas línguas de especialidade, o empréstimo constitui um neônimo. Rondeau (1984:124) refere-se a neonímia de origem (quando um termo novo surge em uma língua de especialidade, resultado de uma nova noção ou objeto) e neônimo de empréstimo (quando a denominação que já foi atribuída por quem concebe uma noção nova passa de uma língua a outra).

Alguns autores diferenciam, assim, o empréstimo externo, o "empréstimo de um termo de uma outra língua", do empréstimo interno, ou seja, "o empréstimo efetuado no âmbito de uma mesma língua, por meio de passagens desse termo a um outro domínio, a um outro registro de língua, ou ambos de língua geral a uma língua de especialidade (Alves, 1995:275278).

Para Rondeau (1984:129), o neônimo é um signo lingüístico do mesmo tipo que o termo, no sentido de que é unívoco, monorreferencial e que a noção que recobre faz parte de um sistema de noções. O neônimo se distingue do neologismo em virtude de três critérios cuja ação é convergente:

a) O critério da consciência coletiva de um grupo de falantes pertencentes a especialistas do domínio, geralmente assistidos por um terminólogo. Contrariamente ao que ocorre em neologia, a opinião dos especialistas de cada domínio é indispensável na neonímia;

b) O critério de uso, que pode ser medido, embora de maneira imperfeita, por meio de documentos científicos ou de termos recentes; este critério deve ser objeto de uma contra-verificação por meio do critério anterior;

c) O critério da datação relativa, obtida graças à verificação nas obras lexicográficas gerais e especializadas.

O empréstimo tem-se mostrado como um processo extremamente produtivo. Em algumas áreas, como a informática por exemplo, é certamente o processo mais produtivo (Assirati, 1998:123). 


\section{A INTEGRAÇÃO DOS ESTRANGEIRISMOS AO PORTUGUÊS}

Embora a tipologia dos dicionários seja bastante diversificada, de maneira geral os dicionários pretendem ser compilações, completas ou parciais, das unidades lexicais de uma língua. O dicionário, repositório da cultura de uma época, de uma sociedade, não só registra, mas também descreve os valores predominantes em determinado momento histórico. $\mathrm{O}$ dicionário constitui-se em livro de referência que tem por objetivo registrar o léxico de uma língua para propiciar ao usuário um instrumento que lhe permita rápido acesso à informação que necessite para compreendê-la.

Para alguns, é também o guardião da pureza da língua, dos seus padrões e de valores morais e ideológicos, já que o dicionarista faz escolhas em relação às palavras que devem ser descritas.

Há uma crença generalizada de que o que está no dicionário está no mundo, ou seja, o dicionário outorga uma espécie de certidão de nascimento a um item lexical, dá-lhe dignidade e o direito e a obrigação de aceitação no acervo da língua. Tal palavra está dicionarizada abre as portas para a inserção no léxico, por mais estranho que seu uso possa parecer ao usuário. No limite, tal postura desemboca na fetichização do dicionário.

Ora, admitindo-se a influência dos estrangeirismos como fato pragmaticamente inevitável, do ponto de vista lingüístico, um bom dicionário há de estabelecer os parâmetros para acolher e definir essas unidades lexicais. Parece-nos que a inserção de uma unidade em um dicionário certamente representa, se não uma consagração definitiva, pelo menos, certamente, uma etapa de uma possível integração ao léxico. O contrário não nos parece necessariamente verdadeiro, ou seja, a não-inserção de um item não o desabilita de maneira irreversível à sua candidatura para futuro registro no acervo lexical da língua. Muitos vocábulos ficam como que flertando, pairando perifericamente, aguardando sua oportunidade.

Guilbert (1975:95-97) ensina-nos que um termo de origem estrangeira deixa de ser neologismo a partir do momento em que entra no sistema lingüístico da língua receptora, ou 
seja, quando deixa de ser percebido como termo estrangeiro. Esta instalação deve ser julgada do ponto de vista dos processos que conduzem à integração e não basear-se exclusivamente no critério de constar em dicionários da língua. Se o termo for consignado em dicionário, esse fato nos informa de determinado uso de um termo especializado mas não esclarece o grau de integração no sistema. Para tanto, prossegue o autor, há vários critérios a serem considerados: critérios fonológicos, semânticos e morfossintáticos. A estes atribui especial importância: quando uma palavra estrangeira serve de base a uma derivação de acordo com o sistema morfossintático da língua receptora está, de fato, se integrando ao novo sistema. O estrangeirismo, em muitos casos, vai sendo flexionado, conjugado, obedecendo à sintaxe do português. É o que acontece com o termo hedge, por exemplo, que vai assumindo as forma de composição com o verbo fazer: não fez hedge, fazer hedge; substantivo: os hedgers; particípio passado: estavam hedgeados; ou, relativamente hedged, conforme se depreende dos exemplos a seguir:

- [ID: 145] - Apesar da diversificação de sua carteira, Magalhães não fez <"hedge"> (proteção) contra uma desvalorização do real. "Não acredito que seja necessário, já que não tenho dívidas em dólar", diz. - (FSP, 23-08-99, p. 2.6, c. 6)

- [ID: 145] - Veja-se, nesse sentido, o exemplo brasileiro, no qual o governo e o Banco Central suportam o ônus de proteger (<"hedge">) o setor privado contra os riscos de mercado e de câmbio - seja por <"hedges"> em moeda estrangeira, seja por obrigações governamentais indexadas às taxas de juros de curto prazo ou à taxa de câmbio. A conseqüência é que os gastos do governo e as taxas de juros são mais altas do que seriam em outras condições, criando, assim, impedimentos naturais a um crescimento mais satisfatório. Pode-se dizer que o Brasil possui um setor privado relativamente "hedged" contra a volatilidade externa, mas paga para isso o preço de uma taxa de crescimento mais baixa. (Rubens Ricupero) - (FSP, 11-08-02, p. B.2, c. 4)

- [ID: 145] - Analistas têm dúvidas se esse montante bastará. "As empresas começaram a fazer <hedge> de suas dívidas, passaram a buscar proteção em dólar para seus recebíveis e até para o patrimônio", diz Natan Blanche, da Tendências. (FSP, 25-06-01, P. B.1, C. 3) 
- [ID: 1963] - Mendonça de Barros qualifica cada um deles: 1) "os bancos arbitradores", que compram e vendem juros e dólar buscando arbitrar a diferença; 2) "os que, assustados, remeteram o dinheiro para fora do país. E saiu mesmo. Este personagem envolve uma gama de operações que vai desde mandar dinheiro para a filial argentina até o cumprimento de ordem da matriz para 'zerar' sua posição no Brasil"; 3) os <"hedgers">, que procuraram proteção contra o risco cambial. - (FSP, 1203-95, p. 2.4, c. 11

- [ID: 250] - "Para Meirelles, a principal delas diz respeito à saúde do sistema financeiro, "já ajustada no primeiro período do Real" (leia-se Proer). Com ele concorda o economista José Alexandre Scheinkman, para quem os bancos estavam "hedgeados" (protegidos) e não sofreram com a desvalorização. Ao contrário, ganharam. "Como quem vendeu o hedge (proteção; no caso, títulos com correção cambial) foi o governo, a crise só viria se houvesse <default> (quebra) do próprio governo", declara. " - (FSP, 27-06-99, p. E.4, c. 2-3)

- [ID: 3] - Veja-se, nesse sentido, o exemplo brasileiro, no qual o governo e o Banco Central suportam o ônus de proteger ("hedge") o setor privado contra os riscos de mercado e de câmbio - seja por "hedges" em moeda estrangeira, seja por obrigações governamentais indexadas às taxas de juros de curto prazo ou à taxa de câmbio. A conseqüência é que os gastos do governo e as taxas de juros são mais altas do que seriam em outras condições, criando assim, impedimentos naturais a um crescimento mais satisfatório. Pode-se dizer que o Brasil possui um setor privado relativamente <"hedged"> contra a volatilidade externa, mas paga para isso o preço de uma taxa de crescimento mais baixa. (Rubens Ricupero) - (FSP, 11-08-02, p. B.2, c. 4)

- [ID: 145] - Grossi diz que o BBV não precisava pagar credores e que investiu em títulos cambiais para proteger seu investimento (fez <"hedge">). "O banco estava descapitalizado, pois seus ativos que não existiam. O dinheiro que entrou no Brasil foi usado para permitir fazer as provisões. O BBV investiv em título cambial para fazer $<$ 'hedge'>. - (FSP, 17-06-01, p. B.7, c. 5)

E, no caso a seguir, surge o estrangeirismo, em função adjetival, complementando a frase portuguesa: 
- [ID: 218] - Apesar dos avanços assinalados até aqui, faltam reformas definitivas que permitam ao setor privado participar no setor de serviços de comercialização e fazer investimentos mais seguros. (...) A importância destas reformas, que substituiriam com vantagem os preços mínimos, se prende ao fato de que, com bolsas e operações bursáteis(?) mais eficientes, a agricultura pode competir mais eficientemente em termos de custos (ser mais <cost effetive>), com preços de insumos e produtos indicando ajustes necessariamente mais rápidos. A agricultura tem potencial de ajuste, mas depende de preços que sinalizem o que tem que ser ajustado. - (CE, 0994, p. 38, c. 3)

Na lexicografia especializada, são produzidos dicionários que abordam diferentes áreas do conhecimento. Nestes dicionários não são registradas palavras usadas na língua geral com finalidades da vida diária e utilizadas por uma variedade de pessoas. Os dicionários especializados preocupam-se com os itens normalmente referidos como termos para diferenciá-los das palavras da língua geral. Já vimos anteriormente a interessante contribuição de Cabré que sugere a designação de unidades lexicais que se concretizarão como termos ou como palavras em função do respectivo contexto.

Constata-se, assim, que a fronteira entre termos e palavras nem sempre é muito clara. Conceitos que já foram, em certo momento, parte de um domínio altamente especializado podem se infiltrar na vida diária das pessoas e os termos que os descrevem podem tornar-se parte de nosso vocabulário geral, mediante um processo conhecido como desterminologização (Meyer \& Mackintosh, 2000, apud Bowker \& Pearson, 2002:26). Os itens contidos em um dicionário de língua geral provêm de várias especialidades. Bowker calcula esse número entre $25 \%$ a $40 \%$. A aceitar-se esse índice, podemos inferir uma verdadeira "labilidade" entre os dicionários de língua geral e os especializados. Há uma permanente complementaridade entre eles. A informação dos dicionários de língua geral a respeito dos itens especializados, contudo, é menos completa, mais rasa do que a informação que os dicionários de língua especializada fornecem. Estes podem ter um objetivo maximizante, prossegue Bowker, buscando atingir uma cobertura abrangente dos termos pertencentes a uma área, ou podem ter um objetivo minimizante, quando pretendem cobrir apenas uma porção limitada do vocabulário especializado pertinente (ou seja, os termos mais usados). De uma maneira geral, os dicionários que têm um escopo mais focado de cobertura (por exemplo, uma subárea) 
tendem a ter um objetivo maximizante, enquanto aqueles com escopo mais amplo tendem a ter um objetivo mais minimizante.

Fazemos estas considerações com o propósito de mostrar que não basta verificar as possíveis inserções de itens lexicais em dicionários de língua geral, mas também se deve buscá-las em dicionários especializados. Há uma significativa porcentagem de terminologias num dicionário de língua geral em virtude das transformações que sofrem a sociedade e a cultura, transformações essas determinadas pelo avanço técnico-científico. Aliás, é a quantidade de unidades especializadas que determina o tamanho de um dicionário de língua, já que o léxico comum tende a ser estável. A presença ou não dessas unidades no dicionário de língua revela o avanço científico da época. Muitos termos presentes em um dicionário em um certo momento são abolidos em outro, quando o referente nomeado evolui ou se torna obsoleto.

Em qualquer um dos casos (empréstimo ou criação vernacular), o neologismo, se tiver êxito, afirmam Cano \& Prado (2006), será submetido a um processo de difusão, que se completará, em parte, ao se ver refletido como entrada em um dicionário de especialidade. Esse marco lexicográfico é fruto habitual do uso contínuo da unidade no discurso da especialidade e constitui um dos índices de referência para se considerar que uma unidade léxica se integrou no novo sistema lingüístico.

Portanto, se esse processo de difusão se desenvolveu com êxito, a próxima vez que um tradutor ou qualquer outra pessoa pergunte ao dicionário sobre esse verbete que passou a fazer parte de sua nomenclatura obterá uma resposta positiva, satisfatória.

Pois bem: quando se poderá obter essa resposta? Ou, dito de outra forma, quanto vai demorar para que o dicionário incorpore a nova unidade na sua nomenclatura?

Os métodos tradicionais do lexicólogo obrigavam a estender o tempo entre uma edição e outra do dicionário; assim, o processo de introdução de um verbete na nomenclatura era lento, e se passava muito tempo até se poder constatar o ingresso de um novo verbete na edição seguinte do dicionário. Ainda hoje este processo ocorre com freqüência. 
Um termo neológico tem que estar suficientemente estável nas trocas comunicativas do grupo que o utiliza para que o dicionário o incorpore. Não em vão se trata de uma codificação distinta, realizada sempre a posteriori, após o uso natural das unidades léxicas nos textos de especialidade. Por isso o dicionário, que segue sempre o uso, trabalha sempre com lentidão, apesar da rapidez que a utilização de procedimentos eletrônicos proporcionou a todo o processo.

Alves (apud Pereira, 2007:9) acrescenta que há dois critérios que revelam a lexicalização de um sintagma: uma formação sintagmática está se lexicalizando se não puder admitir a inserção de outro elemento, que implicaria a alteração semântica do conjunto e supõe o caráter fixo de seus membros integrantes. Acrescidos a esses dois critérios, deve-se levar em consideração a freqüência, ou seja, se o item lexical sintagmático que está se lexicalizando mantiver a mesma apresentação formal e significado constante.

Existe um continuum neologismo/forma lexicalizada que vai desde a criação da nova forma, ou seja, de seu aparecimento em um contexto lingüístico cultural dado, até sua "consagração" ou lexicalização, ou seja, até seu pleno reconhecimento generalizado e sua consignação nas obras lexicográficas como unidade léxica de conhecimento comum.

\section{Palavras Internacionalizadas}

$\mathrm{Na}$ área de Economia, encontram-se com certa frequiência os dicionários de expressões internacionais e de abreviações. Bergenholtz \& Tarp (1995:67) situam estes dicionários numa área de fronteira entre os dicionários monolíngües e os bilíngües, lembrando que esse tipo de dicionário deve sua existência à crescente internacionalização e, geralmente, registra internacionalismos em inglês, utilizados nas relações internacionais que gradualmente estão se incorporando a outras línguas como empréstimos. Como, geralmente, não existem na língua de chegada palavras equivalentes, o dicionário lematiza as expressões internacionais e abreviações, como, por exemplo, Front End Fee e FRCD (Floating rate certificate of deposit), fornecendo informação enciclopédica na língua nativa do usuário. Ou seja, esse tipo, de dicionário sem ser propriamente bilíngüe, assume um caráter de divulgação da língua supostamente preponderante que se sobrepõe às demais. 
Tem esse mesmo caráter a obra Palavras Sem Fronteiras de Sergio Corrêa da Costa (2000), que, interessado na globalização, registra palavras que, originárias de uma língua, foram se insinuando em todas as demais e acabaram por se tornar de uso virtualmente universal. São as palavras de vocação cosmopolita, segundo o autor, que circulam pelo mundo e acabam por integrar uma espécie de vocabulário sem fronteiras que aumenta sem cessar e aproxima as culturas. Esses dicionários "internacionais", além de terem o mérito de registrar uma situação existente de palavras migrando para outras línguas, contribuem também para exacerbar esse processo de influência dos estrangeirismos na sua marcha para se tornarem empréstimos.

Parece-nos que o caráter "internacional” dessas palavras (existem milhares delas) exerce uma função metalingüística sobre as línguas que elas influenciam. 


\section{FORMAS DE APRESENTAÇÃO DOS ESTRANGEIRISMOS}

\subsection{A Questão da Metalinguagem}

Jakobson (1973:127) afirma que uma distinção foi estabelecida na lógica moderna entre dois níveis de linguagem, a linguagem-objeto, que fala de objetos e que se refere à nomeação das coisas, e a metalinguagem, que fala da linguagem, ou seja, tem por objeto a linguagem-objeto. Exercitamos continuamente a metalinguagem, mesmo sem estar, a todo momento, conscientes desse ato.

Quando o emissor e o receptor precisam verificar se o código que utilizam é o mesmo, o discurso está desempenhando a função de se auto-referenciar. Na sala de aula, diz-nos Chalhub (2002:27/28), a relação professor-aluno, diante de uma exposição cognitiva, é uma relação metalingüística. Percebe o que quero dizer? pode ser tanto um teste puramente fático para a verificação do canal como uma antecipação metalingüística. E o que se faz é sempre uma operação substitutiva - própria do código - que fornece informações sobre o código de uso. Se houver afasia do eixo paradigmático - o distúrbio, a dificuldade em substituir termos, conforme diz Jakobson - a tarefa de uso do código estará comprometida. Pierce já nos informava do caráter de representação e de substituição do signo e a sua noção de interpretante - um signo que substitui o signo anterior, ou o significado de um signo é outro signo - equivalente ao funcionamento da operação tradutora da metalinguagem.

Freqüentemente, fazer comentários sobre o texto torna-se necessário para uma melhor comunicação, principalmente quando se objetiva ajustar o discurso àquilo que ele deve designar. Para tanto, a linguagem possui uma "função metalingüística", ou seja, a língua é, às vezes, empregada para se referir à língua.

Para Rey-Debove (1978:1), todo usuário de uma língua encontra nessa língua uma maneira de como estabelecer uma distância entre seu discurso e ele próprio como sujeito de enunciação, e entre seu discurso e o mundo como objeto de enunciação. A função metalingüística é, ao mesmo tempo, um impulso para a linguagem da descrição das línguas e 
uma auto-regulação dos meios de expressão e de comunicação de uma língua. A língua tem a capacidade de se referir a qualquer sistema de linguagem e, portanto, pode falar de si mesma, mas quando uma língua se descreve a si mesma, cria uma situação única. Concretamente, uma determinada língua $\mathrm{L}_{1}$ compreende um subsistema de $\mathrm{L}_{1}$ destinado a se referir a $\mathrm{L}_{1}(\mathrm{e}$ eventualmente a outras línguas), subsistema esse cujo léxico compreende palavras metalingüísticas e palavras autonímicas. Estas palavras, que se designam a si mesmas, são homomorfas de todas as outras palavras do léxico $\mathrm{L}_{1}$. Esta homomorfia desenvolve uma vasta área de ambigüidade no discurso: certas contradições lógicas e certos problemas semânticos provêm de uma confusão homonímica entre os signos que significam coisas e os signos que significam signos, ou que os conotam. São dois sistemas lexicais homônimos que freqüentemente são confundidos, quer por usuários, quer por lingüistas.

As palavras metalingüísticas, cujo estatuto é mais claro, são geralmente percebidas como elementos de uma terminologia especializada. Rey-Debove (1978:2), contrariamente a uma certa visão comum, considera que a descrição correta de uma língua só é possível cuidando-se em primeiro lugar de sua metalinguagem, já que a confusão entre linguagem e metalinguagem pode ser produzida na fonte de qualquer estudo sobre a linguagem.

As palavras autonímicas constituem a nomenclatura completa de um dicionário, pois o sujeito gramatical do discurso lexicográfico é uma palavra que designa uma palavra. Assim, comer é um verbo transitivo, frase é um nome feminino etc. Entretanto, a própria palavra autonímica não é objeto de descrição, é simplesmente empregada no discurso, diferentemente da palavra metalingüística.

Descartadas pelas gramáticas e não assimiladas em sua especificidade pelos dicionários, as palavras metalingüísticas e autonímicas compõem um subsistema que deve ser tratado em seus próprios termos. Trata-se de depreender as regras que se aplicam ao discurso metalingüístico e só a ele, em contraste com as regras do discurso ordinário. O conhecimento das regras da metalinguagem é necessário para se julgar a aceitabilidade das frases metalingüísticas. 
A especificidade da metalinguagem enquanto linguagem, e não enquanto campo semântico, é devida ao fenômeno autonímico que corresponde a uma situação de reflexividade do signo. Esta reflexividade que motiva o signo e bloqueia a sinonímia deve ser estudada em si mesma e pesquisada fora do discurso metalingüístico e do discurso aparentemente "comum" do mundo, derivando ou não de um sistema único.

A metalinguagem não tem por função única falar da língua à qual pertence. Tem o poder de falar de todos os signos de todas as línguas, naturais ou artificiais, ou seja, de todos os signos que não pertencem a seu próprio código e que não decorrem da competência lingüística dos usuários. O discurso metalingüístico, ao utilizar qualquer signo e dele se servir, abre uma larga brecha no sistema das línguas, já que todo fato de discurso pode aí se integrar. Rey-Debove ressalta a utilidade de se estudar o impacto do discurso metalingüístico sobre esses sistemas e que relações eles mantêm com a neologia e com os empréstimos.

Rey-Debove (1978:27) distingue significado mundano de significado lingüístico, ou seja, o significado de um signo que remete ao mundo de um signo que remete à língua, o primeiro sendo um signo comum e o segundo um signo metalingüístico.

Dizer que a metalinguagem estuda a língua-objeto, fala da língua-objeto e não pode falar de outra coisa é dizer mais claramente que ela significa a língua-objeto e significa a ela apenas. Note-se, porém, que a metalinguagem significa a linguagem, mas não a inclui. A competência metalingüística permite produzir frases aceitáveis sobre a língua, especialmente as que afirmam que as frases sobre o mundo são ou não aceitáveis.

(Authier-Revuz, 2001:14) refere-se aos enunciados que:

"em um ponto de seu desenrolar, o dizer representa-se como não falando por si, o signo, em vez de preenchê-lo, transparente, no apagamento de si, de sua função mediadora, interpõe-se como real, presença, corpo - objeto encontrado no trajeto do dizer e que se impõe a ele como objeto -; a enunciação desse signo, em vez de se realizar "simplesmente", no esquecimento que acompanha as 
evidências inquestionáveis, desdobra-se como um comentário de si mesma."

Evocando a "compreensão" como se realizando de maneira "comum e corrente", "por meio da negação do signo", A. Rey (apud Authier-Revuz, 1995,II) observa:

"basta uma incompreensão, uma inquietude, uma necessidade [...] e a língua é relembrada".

A. Culioli (apud Authier-Revuz, 1995:II) analisa como as dificuldades na comunicação verbal, geralmente experimentada como transparente, fazem ressurgir o sentimento de opacidade das palavras.

"[...] já nos apropriamos tanto das palavras que elas parecem ter se tornado um instrumento dócil que obedece nossas intenções [...]. Fascinados pelo sentido [...] não chegamos a levar muito a sério a forma, confundimos facilmente [...] a realidade extralingüística e o instrumento lingüístico [...]. [...] a língua acaba por ser posta em questão, já que não é tão transparente como por vezes a imaginávamos; um mal-entendido pode nos revelar a ambigüidade fundamental das línguas naturais: as palavras, mediadoras por excelência, fazem-nos experimentar sua opacidade e nos revelam que não há uma relação imediata entre as palavras e as coisas.”

Essas "relembranças da linguagem" inscrevem-se em dois planos correspondentes a duas acepções subjetiva e objetiva da construção sob o signo do que Authier-Revuz (1995:II) chama de não-coincidência: é através destas não-coincidências - tudo que marca a nãounicidade da comunicação, ou seja, a incompreensão, a inquietude, a falta, o mal-entendido, a ambigüidade - que "a língua se relembra", em sua realidade, do enunciador o qual, evocado como que a uma certa distância - a do observador em relação ao objeto observado -, deixa de se identificar totalmente com as palavras, estabelecendo uma não-coincidência com as palavras que enuncia. 
Authier-Revuz (1995:8) concebe um certo tipo de configuração meta-enunciativa na qual a enunciação toma um elemento de sua mensagem como objeto. A autora procura identificar as formas concretas de reflexividade meta-enunciativa e detectar no que consiste a especificidade do modo enunciativo. Estabelece a oposição entre dizer X e dizer X e comentar o dizer de $X$.

Tanto Jakobson (1973:127) quanto Rey-Debove (1978:3-4) são autores que enfatizam a importância da propriedade de reflexividade da linguagem: a capacidade de ser sua própria metalinguagem, graças à existência em todas as línguas de um conjunto de formas que permitem assegurar essa reflexividade, que é essencial já que revelada de maneira específica pelas línguas naturais e, como tal, especificamente humana.

Para Jakobson (1973:67), a reflexividade metalingüística é encarada como faculdade (“a faculdade de falar uma língua 'implica' a de falar desta língua”). Diz ele:

"Falar em francês (do ponto de vista da metalinguagem) a respeito do francês (como língua-objeto) e interpretar as palavras e as frases do francês por meio de sinônimos, circunlocuções e paráfrases francesas [...] revela-se parte integrante de nossas atividades usuais".

É que a metalinguagem

“(que) praticamos sem nos darmos conta do caráter metalingüístico de nossas operações [...] desempenha um papel importante na linguagem diária".

Para Benveniste (apud Rey-Debove, 1978:9), a faculdade metalingüística, à qual os lógicos dedicaram mais atenção do que os lingüistas, é caracterizada como a possibilidade que temos de elevar-nos acima da língua, de dela nos abstrairmos, de contemplá-la, utilizando nossos raciocínios e nossas observações. É nesta faculdade metalingüística que encontramos a origem da relação de interpretação por meio da qual a linguagem engloba os outros sistemas. É preciso que nos convençamos de que nada pode ser compreendido que não seja reduzido à 
língua; é graças a este poder de transmutação da experiência em signos e da redução a categorias que a língua pode tomar por objeto qualquer ordem de dados e até sua própria natureza. Existe uma metalinguagem, não existe uma metassociedade.

As duas abordagens globais de reflexividade, que são a definição da função metalingüística por Jakobson e o estudo da metalinguagem natural conduzido por ReyDebove, embora compatíveis, privilegiam dois aspectos distintos do fenômeno: onde uma visa apreender a reflexividade como dimensão da prática lingüística, a outra se preocupa, antes de tudo, em fazer o inventário e a descrição das formas da língua da reflexividade. É desse ponto de vista duplo que Authier-Revuz trata a reflexividade.

\section{O metaléxico}

O léxico é constituído pelo conjunto de palavras de uma língua, ou seja, o conjunto de unidades codificadas significantes livres mínimas (Bloomfield) que servem como integrantes da frase (Benveniste 1966:119-131, apud Rey-Debove, 1978:25).

O léxico pertence à língua por oposição ao discurso, provém do sistema e da norma, como dado social, e não do discurso, como fenômeno individual. O léxico de uma língua compreende:

a) um conjunto de palavras mundanas, que servem para falar das coisas e do mundo, para falar daquilo que não é língua; estas palavras representam todas as categorias gramaticais da língua;

b) Um conjunto de palavras metalingüísticas, que servem para falar da linguagem, por exemplo, adjetivo, dizer, gramaticalmente; estas palavras também representam todas as categorias da língua;

c) Um conjunto de palavras neutras em relação às outras duas categorias, e que a elas se integram indiferentemente; são palavras de alta freqüência, de conteúdo pobre, polivalentes ou temáticas; representam todas as categorias gramaticais e 
especialmente as palavras gramaticais (altas freqüências) que, em sua generalidade, são indiferentes aos domínios semânticos em que funcionam.

O léxico de uma língua é, portanto, composto de um léxico que fala do mundo (léxico mundano da língua-objeto), de um léxico que fala da língua (metaléxico ou metalinguagem) e de um léxico neutro que contém todas as palavras temáticas de alta freqüência, palavras lexicais e gramaticais suscetíveis de entrarem em qualquer discurso, em ocorrência mundana ou metalingüística. Pode-se considerar que as palavras neutras pertencem tanto à línguaobjeto quanto à metalinguagem e que uma parte do léxico é a interseção das duas.

As palavras metalingüísticas serão, por exemplo:

a) palavras que tenham um sentido metalingüístico (seja este sentido o único ou não);

b) palavras que tenham um sentido neutro ou não (seja este sentido o único ou não).

\section{Palavras Autonímicas}

Os lexicólogos nunca consideraram as palavras autonímicas como pertencendo ao campo de descrição lexical, já que sempre foram confundidas com as palavras da expressão respectiva, pois as palavras autonímicas são homônimas das palavras que designam. As palavras autonímicas são signos lingüísticos de signos lingüísticos, e, portanto, palavras metalingüísticas (embora sua semântica e propriedades sintáticas sejam radicalmente diferentes).

O metaléxico de uma língua compreende, portanto, palavras metalingüísticas e palavras autonímicas, homônimas de todas as outras (mundanas e metalingüísticas). As palavras metalingüísticas participam do sistema mundano pela sintaxe e do sistema autonímico pela semântica.

As palavras metalingüísticas mais freqüentes, assim como as mais representativas, são os nomes e principalmente os substantivos e os verbos. As palavras metalingüísticas são de 
preferência palavras lexicais (nomes, adjetivos, qualificativos, advérbios formados a partir de adjetivos). Isto não exclui, porém, as palavras gramaticais de baixa frequiência.

\section{O signo autonímico}

O signo do signo é um signo autonímico. A autonímia é tradicionalmente um tema da filosofia da linguagem. Os filósofos que se ocupam da autonímia a concebem como uma teoria de referência em que os signos se opõem às coisas, em que os signos são os nomes das coisas, ponto de vista esse que não interessa ao lingüista. A este cabe situar e descrever a autonímia em uma teoria da significação em que os signos são considerados intrinsecamente, na relação entre significante e significado. A regra autonímica é uma regra semântica geral, a mesma para todas as palavras, e o fenômeno autonímico ultrapassa de longe, mesmo lexicalmente, o que pode ser descrito como constituindo o léxico de uma língua (Rey-Debove, 1978:).

Todas as línguas têm a possibilidade de falar de si mesmas, ou seja, todas têm uma metalinguagem. Comparando-se as palavras metalingüísticas stricto sensu e os signos autonímicos, a prioridade genética e hierárquica do signo autonímico fica evidente.

Os caracteres morfossintáticos do signo autonímico de cada língua se manifestam mais extensivamente na adaptação de textos estrangeiros. A maioria dos textos que falam das coisas e dos signos que os designam dão lugar a interpretações falhas em um momento dado; ao não-sentido e ao contra-sentido (frase assemântica) (Rey-Debove, 1978:69).

O signo apresenta-se completo com seu significante e seu significado: esta característica está situada no centro da problemática da autonímia. Geralmente se utiliza um apresentador metalingüístico: o significante $X$, a expressão $X$, o conteúdo $X$. As marcas específicas do significante são às vezes colchetes, às vezes espaços entre as linhas; as marcas de significação são aspas. O significante é representado tanto como gráfico, como também como fônico (Rey-Debove, 1978: 81) 
O sistema interlingüístico apresenta os mesmos tipos de autonimização que o sistema intralingüístico, mas a introdução de itens estranhos perturba gravemente o sistema que o hospeda.

Rey-Debove (1978:88) afirma que o fenômeno autonímico toca os problemas fundamentais da lingüística, trazendo a questão da relação entre a palavra e o nome, entre o nome-substantivo e o nome-nome, entre o nome próprio e o nome comum; a relação entre o signo lingüístico e o signo não-lingüístico, entre o signo lingüístico e a coisa; a relação entre o significado lexical e o significado frástico; a relação entre o signo e o significante; entre a apresentação de uma coisa e sua representação por um signo; entre o uso de um signo e o significado de um signo.

Uma frase bem formada significa alguma coisa. Este significado é a síntese complexa (não a soma) dos significantes dos signos que a compõem. Admite-se que um significante possa apresentar buracos no domínio do denotado, mas não no domínio do significado. Todos os itens de uma frase significante significam. O signo é formado de um significante e de um significado ligados de maneira indissociável. É o significado que determina a função do signo na frase, sendo as estruturas profundas, semânticas. A própria dualidade significante / significado é uma visão metalingüística sobre o signo, porque não existe, nas manifestações lingüísticas, nem significante nem significado em estado isolado.

A noção de reflexividade se impõe, em relação à autonímia, na medida em que a define como signo "que designa a si mesmo, que é o nome de si mesmo etc". A conseqüência direta da reflexibilidade é a motivação do signo autonímico. Entende-se por motivação do signo, conforme Rey-Debove (1978:128), a relação não-convencional que une o signo a seu designatum, por oposição ao princípio geral da arbitrariedade do signo. Essa relação que se pode dizer "natural" é, na maioria das vezes, uma relação de semelhança.

\section{A conotação autonímica}

O sistema semiótico da conotação, definido por Hjelmslev, é o sistema inverso da metalinguagem: é a expressão que constitui um signo, e não o conteúdo, de acordo com a 
fórmula $\mathrm{E} \mathrm{C} \mathrm{(C).} \mathrm{Enquanto} \mathrm{a} \mathrm{metalinguagem} \mathrm{é} \mathrm{um} \mathrm{sistema} \mathrm{complexo} \mathrm{formalmente} \mathrm{reforçado}$ (duas expressões para um conteúdo), a conotação é um sistema complexo formalmente enfraquecido (dois conteúdos para uma expressão). É por esta razão que é de tratamento difícil em linguiística.

\subsection{Tipologia dos Discursos Científicos e Definição}

Há um grande número de discursos diferentes. Às vezes, fala-se da linguagem científica como se se tratasse de um único estilo característico dos cientistas, não importando seu nível de estudo, sua situação profissional e seu campo de trabalho, sua capacidade de expressão e de redação. Isto permite desenvolver diferentes visões da língua, quer se as considere científica, de especialização, de divulgação, mas todas diferentes da língua geral. O tipo de linguagem não será o mesmo, conforme se escreva para uma revista de especialistas que conhecem as bases de domínio científico em questão ou para um veículo de divulgação, mesmo que seja nas colunas científicas diárias de um jornal. $\mathrm{O}$ emissor é geralmente um jornalista, um pesquisador (ou porta-voz deste). O receptor é diversificado no discurso científico especializado; tanto o emissor quanto o receptor podem ter conhecimento suficiente da área, enfrentando eventuais dificuldades de compreensão. Já num discurso de semivulgarização científica, o emissor é um profissional especialista de uma área científica. O receptor pode, teoricamente, ser qualquer leitor, mas a compreensão de um texto exige sólidos conhecimentos básicos e uma respectiva cultura científica. No discurso de vulgarização científica, o emissor é geralmente um jornalista profissional; mesmo que ele seja especializado em uma área, ele não realiza pesquisas no campo. O receptor pode ser qualquer pessoa em busca de informações com acesso relativamente fácil, que permita uma compreensão rápida e fácil sem exigir conhecimentos fundamentais. Os veículos em que esse tipo de texto ocorrem são geralmente jornais e/ou revistas de grande circulação, diários ou semanais, de interesse e acesso de um grande público. Cada tipo de discurso comporta um certo número de características linguiísticas que fazem parte da linguagem adequada à situação de comunicação particular. Segundo Laurian (1983:13), no nível da vulgarização há uma maior abundância de vocabulário científico. Ou seja, quanto mais o campo de discurso é especializado, mais o domínio coberto é restrito. 


\section{Definição}

Segundo Sager (1990:40), a definição é geralmente entendida como o processo de explicar o significado de símbolos expressos lingüisticamente. Como produto, a definição é uma descrição lingüística de um conceito, baseada em uma série de características que transmitem o significado do conceito. Assume a forma de uma simples predicação a respeito de uma palavra ou expressão e pode também ser considerada como uma equação de termo desconhecido e a soma de seus elementos constituídos de significado. As definições especializadas descrevem um conceito no âmbito de um campo específico.

As definições proporcionam uma ligação entre conceitos e termos por meio de uma equação na qual o definiendum é o termo. A definição terminológica fornece uma identificação única de um conceito em relação ao sistema conceitual do qual o termo faz parte e classifica o conceito dentro desse sistema. Na terminologia, lembra Sager (1990:40) é habitual restringir-se o uso da "definição" à explicação dos significados especializados aceitos dos itens lexicais cuja ocorrência pode ser documentada em diversas fontes.

Na teoria da terminologia, a natureza do referencial especial conduz a uma abordagem diferente no método da definição. Por convenção, certos itens lexicais são considerados destituídos de qualquer significado que não seja o referencial no âmbito do domínio de uso considerado, ou seja, na área especializada. Embora uma palavra possa ser definida por meio de seus sinônimos, o mesmo não acontece com um termo. Um conceito não pode ser definido por sinônimos de um termo já que isto redundaria em tautologia. O conceito pode, contudo, ser definido por todos os conceitos que o circundam na área de especialidade em que ocorrem.

Um aspecto dos discursos científicos consiste na utilização de formas definitórias e na presença de definições, o que ocorre na interseção dos caminhos da sintaxe e da semântica. Uma das formas de apresentação visando à reformulação ou explicitação do estrangeirismo consiste em explicar o significado do termo. A definição é um dos recursos mais freqüentes para essa finalidade. No corpus analisado, as definições ocorrem, de maneira geral, após o registro do termo estrangeiro: 
- [ID: 88] - O <"benchmark"> é um indicador que o administrador de recursos usa como referência para deixar claro o objetivo de rentabilidade do fundo. Com base nesse indicador, o investidor pode conferir se o fundo entregou o que vendeu. Nem sempre isso acontece. - (FSP, 07-02-00, p. 2.6, c. 6)

- [ID: 146] - <"Swap"> é uma operação de troca de indexador. Se uma empresa tem uma dívida, por exemplo, indexada ao dólar, mas teme que a cotação dessa moeda venha a subir muito, ela pode procurar uma instituição financeira e solicitar um <"swap">, isto é, que a variação cambial do seu contrato seja trocada por outro indexador. - (FSP, 05-03-02, p. B.6, c. 3)

- [ID: 322] - Na Nasdaq, a Bolsa eletrônica que reúne as empresas do setor de tecnologia nos EUA, a reação à entrada da Microsoft na Globo Cabo foi mais rápida: a ADR (<American Depositary Receipł>), papel emitido e negociado nos EUA com lastro em ações de outros países, que chegou a ser negociada a apenas US $\$ 1$, em 25 de março, era cotada a US\$ 6,30, quando iniciaram as negociações com a Microsoft. - (FSP, 18-10-99, p. 2.6, c. 3)

mas também ocorrem antes do registro do termo estrangeiro:

- [ID: 727] - "O principal título da dívida externa, o <C Bond>, pagava, até semana passada, um prêmio em torno de 400 centésimos de porcentagem acima dos títulos do Tesouro americano. - (FSP, 29-10-97, p. 2. 13, c. 3)

- [ID: 241] - Foi o que aconteceu na Argentina, onde o fracasso de sucessivos planos de estabilização levou à crença na incapacidade do governo em adotar ações efetivas na defesa da moeda nacional. (...) Ante este quadro, surge, de forma quase natural, a idéia da adoção de um regime monetário baseado no princípio de que o banco central se transforme numa simples caixa de conversão (<currency board>) como maneira de solucionar o problema. Este sistema é simples e funciona bem no curto prazo: a) é fixada uma paridade entre a moeda nacional e a moeda estrangeira: b) o banco central só admite variar a base monetária a partir de uma variação das reservas internacionais, permanecendo constante em termos nominais o crédito interno líquido. É necessário entender as suas qualidades e defeitos. - (CE, 06-95, p. 46, c.1-2) 
- [ID: 773] - Os EUA têm a prática de vender produtos em outro mercado abaixo do preço de custo (<dumping>), condenada por Brasil e Japão - (FSP, 28-11-99, especial.4, c. 4)

Laurian (1983:15) diz-nos que uma definição deve ser universal, atemporal, nãocircunstancial e impessoal em relação a quem a formula. Todos os pronomes pessoais devem ser banidos, assim como toda modalização e toda temporalidade. Estabelece a autora cinco grandes categorias definitórias nos discursos científicos:

1) Denominação: quando um dos elementos é lingüisticamente de grande extensão e o outro fornece um complemento de informação. $\mathrm{O}$ elemento que define o outro pode se encontrar tanto antes quanto depois dele, sendo que a ligação se faz por meio de um verbo específico. A denominação é empregada freqüentemente no discurso pedagógico (obras de ensino dirigidas a estudantes), no discurso altamente especializado e também no de divulgação.

O verbo-tipo desta categoria é chamar-se, agrupando o conjunto constituído por nomear, designar, dizer. Por exemplo:

- [ID: 706] - Em segundo lugar nessa lista ficaram as empresas da área de alimentos e bebidas, que, no mesmo período, enviaram US $\$ 1,172$ bilhão a seus acionistas estrangeiros. Logo depois, vieram as chamadas <"holdings">, empresas cujo único negócio é administrar outras empresas e que mandaram US $\$ 1,015$ bilhão para fora do país nesses 15 meses. [Ney Hayachi da Cruz] - (FSP, 14-05-06, p. B.7, c. 1)

- [ID: 2151] - Setubal diz que o Brasil precisa melhorar sua nota ("rating") atribuída pelas instituições internacionais de classificação de risco. Para ele, o país tem rapidamente que atingir o nível na qual essas instituições recomendam investimento (chamado de <"investment grade">). E, para isso, de acordo com Setubal, são necessários disciplina monetária, equilíbrio fiscal e democracia em funcionamento. (FSP, 05-08-01, p. B.2, c. 1-2)

- [ID: 109] - [...] Com as taxas de juros vigentes no período, isso levou muitos desses fundos a atuarem de forma cautelosa, muitas vezes realizando operações casadas 
nesses mercados (apelidadas "operações de <box>"), que se caracterizavam por, na prática, serem operações de renda fixa. - (CE, 01-96, p. 25, c. 1)

- [ID: 406] - O que existe é a disputa entre indústria e comércio para ver quem vai ficar com o <"floating">. Este é o nome que os economistas dão ao ganho que a inflação propicia quando há prazo entre a venda e o pagamento. Os supermercados, por exemplo, compram a prazo e vendem à vista. Logo, podiam aceitar que os preços da indústria embutissem o custo financeiro, já que os recursos obtidos nas vendas poderiam ficar aplicados por até 20 dias. - (FSP, 26-06-94, p. 2.4, C. 1)

- [ID: 1501] - <Chinese wall> - Forma de designar a separação dos recursos próprios da instituição financeira daqueles que ela administra para os clientes - (FSP, 13-11-00, p. F.7, c. 1)

2) Equivalência: utiliza com freqüência o verbo-cópula ser. É este o verbo mais empregado. Alguns sinais de pontuação, como por exemplo, parênteses, podem desempenhar o mesmo papel. A equivalência é o único caso em que a definição pode ser aproximada. Representa uma exceção à regra de nãomodalização enunciada acima. À lista dos verbos-cópula pertencem, por exemplo, consistir, constituir, exprimir, considerar como, representar.

Laurian (1983:17) diz-nos que a equivalência é utilizada em todos os tipos de discursos científicos da série "especializado - semidivulgação - divulgação", mas exclui a do tipo pedagógica. Por exemplo:

- [ID: 145] - O BC fez tudo errado. Quando aumentou os juros pela primeira vez, estava claro que iríamos entrar num período conturbado, devido ao problema mais grave da Argentina. Nesses momentos, há uma corrida natural por <hedge> [proteção contra a variação do dólar]. - (FSP, 22-04-01, p. B.9, c. 1)

- [ID: 146] - O mercado futuro de câmbio comercial da BM\&F movimentou $R \$ 8,8$ bilhões por dia, no ano passado. O futuro de juros (DI) movimentou $R \$ 13,4$ bilhões por dia. E o mercado de <"SWAPS"> [troca de empréstimos entre duas partes para proteção contra eventuais perdas] - que envolve trocas de posições entre juros pré e 
pós-fixados e entre juros e dólares - girou $R \$ 8,3$ bilhões por dia. Os três somaram os $R \$$ 30,5 bilhões citados no início deste texto. - (FSP, 20-05-99, p. E.1, c. 3)

- [ID: 248] - "Quase junto com a circular, O BC chamou os <"dealers"> (instituições através das quais $O B C$ negocia com o mercado) para uma reunião às $11 \mathrm{~h} \mathrm{em}$ Brasília. O sistema de <"dealers"> é uma excrescência brasileira antiga e anacrônica, que permite a meia dúzia de privilegiados saberem antes dos demais os rumos que 0 BC pretende imprimir ao mercado. - (FSP, 12-03-95, p. 2.3, c. 2)

- [ID: 391] - O serviço de <factoring> aumentou $266 \%$ desde 1994. A estabilidade econômica é a principal causadora do crescimento desse setor de fomento mercantil. O volume de recursos movimentado por esse mercado passou de 6,1 bilhões para R $\$ 16$ bilhões em 1999. <Factoring> é um conjunto de serviços oferecidos por empresas, chamadas de sociedades de fomento mercantil, a micro e pequenas empresas. - (FSP, 20-12-99, p. 3.4, c. 5)

3) Caracterização: há inúmeras maneiras de introduzir as caracterizações existentes na língua. As adjetivações nominais são as mais freqüentes (adjetivos ou relativos); as adjetivações verbais (advérbios, modalizadores etc.) também podem exprimi-las. Os discursos científicos, de natureza acentuadamente nominal, recorrem com freqüência à definição do tipo caracterização por meio de adjetivações nominais.

A caracterização pode se apresentar sob a forma de uma verdadeira complementação, do ponto de vista sintático.

Pode igualmente ser objeto de uma proposição bem individualizada, independente no plano sintático, mas compondo uma definição do ponto de vista semântico, em ligação com um outro enunciado.

As palavras-tipo da caracterização são os relatores. Estes compreendem os pronomes relativos propriamente ditos e também os sinais tipográficos ou relações semânticas devidas a certas formulações tanto no plano sintático quanto no lexical. 
A caracterização nas definições ou para definir um objeto é particularmente utilizada nos discursos de divulgação ou pedagógico. Por exemplo:

- [ID: 179] - Há ainda dois nós a ser desatados para deslanchar o ambicioso projeto prioritário, ressalta o consultor Jean-Paul Prates, sócio da Expetro e da Prates \& Carneiro Advogados, firmas que prestam assessoria a empresas do ramo. Um é o risco cambial, já que o gás é uma <commodity> (cotada em dólar) e a receita das termelétricas vem em reais. As operações precisam de um seguro, que envolve um custo. "Quem assume isso?" é questionamento comum de mais de uma centena de uma centena de empresas com ambição de entrar no mercado. - (FSP, 20-08-00, p. B.4, C. 4)

- [ID: 400] - A Secretaria do Trabalho demonstra, em recente estudo, que o índice de preços cobrados por indústrias nas transações de <first sell> (que exclui intermediários) está há seis meses variando entre o estacionamento e a queda. Nos últimos 12 meses, esse mesmo índice (que inclui produtos voláteis, como alimentícios e energia) subiu apenas 3\%. Esse novo índice, que em termos de modelo é igual ao velho preço no atacado, é bastante relevante, pois nos últimos dez anos cresceu em $50 \%$ o número de bens que saem diretamente das linhas de produção para o comércio no varejo. - (CE, 03-94, p. 57, c. 1)

- [ID: 1457] - Nos últimos dias de maio, a correlação do Ibovespa (Índice da Bolsa de Valores de São Paulo) com o <Dow Jones> (principal índice da Bolsa de Nova York) aumentou drasticamente. Ou seja, a Bolsa brasileira oscilou mais por conta dos movimentos no mercado americano do que propriamente pelos eventos internos. (FSP, 31-05-99, p. 2.1, c. 3)0

4) Análise: a análise consiste na decomposição de um objeto em elementos de tal forma que ao juntarem-se todos os elementos, uns aos outros, obtém-se o objeto em questão. Pode-se considerar como análise a soma das propriedades do objeto ao ser definido. Isto significa que se admite, ao mesmo tempo, a soma dos equivalentes menores ou a soma das caracterizações constantes das categorias anteriores.

A palavra-tipo nesta categoria é compreender, conter, abranger e as expressões mais freqüentes são: ser composto de, ser constituído de, compor-se de. 
Aqui ocorre uma dominância de formas não-ativas. Esse tipo de definição é característico do discurso pedagógico. Está igualmente presente até nos textos especializados e semivulgarizados, mas deve-se observar que se encontram geralmente no inicio do texto, no momento em que o autor lança as bases do que vai ser desenvolvido. Por exemplo:

- [ID: 114] - A <"brainstorming"> é a técnica de como contornar as causas do problema. As regras aqui são quatro: falar o que vem à cabeça, procurar quantidade, dar idéias originais e combinar idéias para melhorar a produção. - (FSP, $02-04-95$, p. 2.9, c. 2$)$

- [ID: 145] - <Hedge> - Operação financeira realizada por meio de contratos para aquisição futura de um ativo a um preço predeterminado; usado como proteção contra a oscilação de preços no mercado financeiro. - (FSP, 13-11-00, p. F.7, c. 2)

- [ID: 146] - <"Swap"> é uma operação de troca de indexador. Se uma empresa tem uma dívida, por exemplo, indexada ao dólar, mas teme que a cotação dessa moeda venha a subir muito, ela pode procurar uma instituição financeira e solicitar um <"swap">, isto é, que a variação cambial do seu contrato seja trocada por outro indexador. - (FSP, 05-03-02, p. B.6, c. 3)

5) Função: este tipo de definição apóia-se na finalidade do objeto, no seu uso e possibilidades, eventualmente sobre seus efeitos.

O verbo-tipo é permitir. Há várias realizações: empregar para, utilizar para, conduzir a. Este tipo de definição é peculiar à divulgação. Se encontrado em outro tipo de discurso, não é em sua forma "pura". Por exemplo:

- [ID: 44] - A proteção à indústria nacional (entendida como indústria instalada no Brasil) se dará por mecanismos <antidumping> (que impeçam a entrada de produtos com preços abaixo do custo) e sistemas de proteção contra os abusos de poder econômico -- no caso, o Conselho Administrativo de Direito Econômico (Cade). (FSP, 24-11-96, p. 2.3, c. 4)

- [ID: 508] - É uma solução que convém em princípio ao governo americano, que, embora demonstre de público certa pressa, não pode acelerar as negociações por falta da TPA (Trade Promotion Authority). É o novo nome para <"fast track">, 
mecanismo pelo qual o Congresso dá poderes ao Executivo para negociar acordos que, depois, o Parlamento apenas rejeita ou aprova em bloco, mas não emenda. (FSP, 01-04-01, p. B.5, C. 6)

6) Zonas-limites: quando se definem tipos, determinados casos escapam à definição participando de vários tipos simultaneamente. Há sempre zonas fronteiriças ou, conforme o contexto, que pertencem a um tipo ou outro.

Ocorre freqüentemente uma zona limítrofe entre a função e a categorização. Parece que são, sobretudo, os discursos do tipo especializado e semivulgarizado que praticam tais definições. Por exemplo, (denominação + função):

- [ID: 729] - "A queda das ações na Bolsa de Nova York anteontem fez com que fosse acionado um dispositivo chamado <"circuit breaker">, que interrompe as operações ao longo do dia. $O$ <"circuit breaker"> foi criado depois do crash de 1987 e ainda não tinha sido utilizado durante os pregões. Ele atua como uma espécie de dispositivo de segurança eletrônico. - (FSP, 29-10-97, p. 2.6, c. 3)

Há, ainda, outra zona-limite: a que separa a definição de um objeto de sua simples constatação de existência. De fato, a denominação desempenha um pouco esse papel de zona intermediária.

Os parâmetros propostos por Laurian (1983:19), a presença da definição e o tipo de definição existente redundam em:

1) Discurso científico especializado: as definições são extremamente raras. Quando ocorrem, trata-se de início do texto, e são de todos os tipos, com exceção de Função;

2) Discurso de semidivulgação: utiliza principalmente definições do tipo Análise e Função;

3) Discursos de divulgação: as definições, elaboradas para esclarecer o leitor como também para dar uma aparência de cientificidade (= objetividade?) pertencem a todos os tipos, com exceção de Caracterização. 
4) Discurso pedagógico: os tipos de definição utilizados são principalmente Denominação, Caracterização e Análise. Há pouca Equivalência e Função.

\subsection{Tipologia das Formas de Apresentação dos Estrangeirismos}

Procedemos à analise dos contextos contendo os estrangeirismos com o objetivo de verificar as diversas formas de apresentação. Nas fichas terminológicas há um total de 962 contextos distribuídos de maneira desigual entre os termos estrangeiros: procuramos estabelecer uma "equação" sintética que refletisse o padrão de cada construção de frase envolvendo o estrangeirismo, considerando também os recursos gráficos utilizados (aspas, parênteses, colchetes, negrito, itálico, travessão).

A “equação" procura descrever a forma de apresentação do estrangeirismo, como por exemplo:

E (def. port.), ou seja, ocorre o estrangeirismo e, em seguida, vem a definição em português entre parênteses, como por exemplo:

- [ID: 179] - Na avaliação do governo e de analistas, isso ocorreu principalmente por causa da piora do cenário internacional. A queda dos preços das <commodities> (café, soja, açúcar etc.), o aumento do preço do petróleo e a crise que atingiu também os países da América Latina, reduzindo a demanda por produtos brasileiros, são as causas mais citadas. - (FSP, 02-01-00, p. 2.1 , c. 4)

tradução, E, ou seja, a tradução em português vem antes do estrangeirismo, separado por virgula, por exemplo:

- [ID: 2292] - No mundo da finança desregulamentada, os administradores da riqueza líquida - fundos de pensão, fundos mútuos, <hedge funds> -, no afã de carrear mais dinheiro para os seus fundos e na ânsia de bater os concorrentes, prometem mundos e fundos aos clientes. [Luiz Gonzaga Belluzzo] - (FSP, 23-11-03, p. B.2, c. 5) 
O termo definição, foi utilizado de maneira genérica e ampla, abrangendo não só definições analíticas, por função, sintéticas etc, bem como qualquer tipo de explicação que esclareça o significado do termo.

A seguir, tabela resultante da classificação dos contextos:

\begin{tabular}{|c|c|c|c|}
\hline $\mathbf{N}^{\mathbf{o}}$ & Tipos & $\begin{array}{l}\text { Número de } \\
\text { ocorrências }\end{array}$ & $\begin{array}{c}\text { \% de } \\
\text { ocorrências }\end{array}$ \\
\hline 1 & $E$ (def. port. $)$ & 39 & 4,054 \\
\hline 2 & "E" (def. port.) & 51 & 5,301 \\
\hline 3 & 'E'. A expressão em inglês corresponde def. port. & 1 & 0,103 \\
\hline 4 & a técnica chamada E (tradução) & 1 & 0,103 \\
\hline 5 & Alguns termos nem têm tradução, expressam um conceito. & 1 & 0,103 \\
\hline 6 & ao pé da letra, E significa $\underline{X}$, em inglês. & 1 & 0,103 \\
\hline 7 & conhecidas pelo nome de $\mathrm{E}$. & 1 & 0,103 \\
\hline 8 & (apelidadas "operações de E") def. port. & 1 & 0,103 \\
\hline 9 & (as chamadas $\mathrm{E}$ ) & 1 & 0,103 \\
\hline 10 & as chamadas $E-$ def. port. & 1 & 0,103 \\
\hline 11 & "E" "em caixa alta" [def. port.] & 1 & 0,103 \\
\hline 12 & as chamadas "E", def. port. & 1 & 0,103 \\
\hline 13 & as chamadas $E$, ou def. port., de acordo com o jargão local & 1 & 0,103 \\
\hline 14 & chamadas E, por exemplo, & 1 & 0,103 \\
\hline 15 & def. port., chamado "E" & 1 & 0,103 \\
\hline 16 & (chamado de E), dois exemplos & 1 & 0,103 \\
\hline 17 & tradução (“E”) & 1 & 0,103 \\
\hline
\end{tabular}




\begin{tabular}{|c|c|c|c|}
\hline $\mathbf{N}^{\mathbf{o}}$ & Tipos & $\begin{array}{l}\text { Número de } \\
\text { ocorrências }\end{array}$ & $\begin{array}{c}\% \text { de } \\
\text { ocorrências }\end{array}$ \\
\hline 18 & (chamado de "E") & 1 & 0,103 \\
\hline 19 & classificado como $\mathrm{E}$ & 1 & 0,103 \\
\hline 20 & como E & 3 & 0,311 \\
\hline 21 & como os "E" e "E" & 2 & 0,207 \\
\hline 22 & "E", como é chamada & 2 & 0,207 \\
\hline 23 & E, como foi apelidado & 1 & 0,103 \\
\hline 24 & 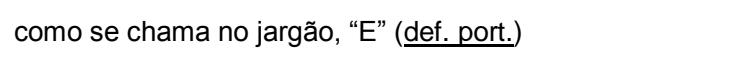 & 1 & 0,103 \\
\hline 25 & $\begin{array}{l}\text { "E", como se diz em inglês ou tradução, como se diz por } \\
\text { aqui }\end{array}$ & 1 & 0,103 \\
\hline 26 & "E" (tradução, como se diz em inglês) & 1 & 0,103 \\
\hline 27 & conhecida no direito anglo-saxão como $E$ & 1 & 0,103 \\
\hline 28 & $E$, que numa tradução livre seria algo como def. port. & 1 & 0,103 \\
\hline 29 & conhecido em economês como E: def. port. & 1 & 0,103 \\
\hline 30 & conhecida no mercado como " $E$ " & 1 & 0,103 \\
\hline 31 & conhecido(s) como"E" & 2 & 0,207 \\
\hline 32 & conhecida(s) como E & 2 & 0,207 \\
\hline 33 & conhecidos como $E$ & 1 & 0,103 \\
\hline 34 & def. port. (conhecidos como “E”) & 1 & 0,103 \\
\hline 35 & $\underline{\text { sintagma em port. (“E”) }}$ & 1 & 0,103 \\
\hline 36 & def. port. $($ ser $+E)$ & 1 & 0,103 \\
\hline 37 & def. port. como sintagma port. $+E$ & 1 & 0,103 \\
\hline 38 & $\underline{\text { sintagma port. }}+$ "E" & 1 & 0,103 \\
\hline
\end{tabular}




\begin{tabular}{|c|c|c|c|}
\hline $\mathbf{N}^{\mathbf{o}}$ & Tipos & $\begin{array}{l}\text { Número de } \\
\text { ocorrências }\end{array}$ & $\begin{array}{c}\% \text { de } \\
\text { ocorrências }\end{array}$ \\
\hline 39 & def. port., $E$, & 1 & 0,103 \\
\hline 40 & def. port. - são $E$ & 1 & 0,103 \\
\hline 41 & def. port. "E" & 4 & 0,415 \\
\hline 42 & def. port., ou "E" (tradução) & 1 & 0,103 \\
\hline 43 & tradução, $\mathrm{E}$ & 2 & 0,207 \\
\hline 44 & def. port., como E & 1 & 0,103 \\
\hline 45 & def. port. $(E)$ & 17 & 1,767 \\
\hline 46 & "E" def. port. & 47 & 4,885 \\
\hline 47 & $E$ (def. port.) & 4 & 0,415 \\
\hline 48 & E def. port. & 46 & 4,781 \\
\hline 49 & $\underline{\text { destaque em azul E def. port. }}$ & 1 & 0,103 \\
\hline 50 & destaque em azul E def. port. & 1 & 0,103 \\
\hline 51 & dispositivo chamado "E" def. port. & 1 & 0,103 \\
\hline 52 & E - Diz-se def. port. & 1 & 0,103 \\
\hline 53 & E - tradução. Diz-se def. port. & 1 & 0,103 \\
\hline 54 & E sigla, do inglês "E" por extenso def. port. & 1 & 0,103 \\
\hline 55 & E sigla (do inglês " $E$ " por extenso, ou seja, def. port.) & 1 & 0,103 \\
\hline 56 & é chamado de "E", que significa tradução em inglês. & 1 & 0,103 \\
\hline 57 & E. Este é o nome que os economistas dão & 1 & 0,103 \\
\hline 58 & E sigla E (por extenso). É o novo nome para "E", def. port. & 2 & 0,207 \\
\hline 59 & "E" é o termo que significa "tradução", def. port. & 1 & 0,103 \\
\hline
\end{tabular}




\begin{tabular}{|c|c|c|c|}
\hline $\mathbf{N}^{\mathbf{0}}$ & Tipos & $\begin{array}{l}\text { Número de } \\
\text { ocorrências }\end{array}$ & $\begin{array}{c}\% \text { de } \\
\text { ocorrências }\end{array}$ \\
\hline 60 & "E": tradução em inglês & 1 & 0,103 \\
\hline 61 & "E": (tradução em inglês) & 4 & 0,415 \\
\hline 62 & def. port. ("E", em inglês) & 1 & 0,103 \\
\hline 63 & o nome "E" em inglês, isto é tradução & 1 & 0,103 \\
\hline 64 & "E" (tradução, em inglês) def. port. & 1 & 0,103 \\
\hline 65 & $\mathrm{E}$, em inglês, quer dizer def. port. & 1 & 0,103 \\
\hline 66 & E (em português, "tradução") def. port. & 1 & 0,103 \\
\hline 67 & tradução (ou $E$, em português pós-moderno) & 1 & 0,103 \\
\hline 68 & def. port. (aqui entendidos como um dos " $\mathrm{E}$ ") & 1 & 0,103 \\
\hline 69 & “E” (espécie de tradução) & 1 & 0,103 \\
\hline 70 & E (especificação) & 1 & 0,103 \\
\hline 71 & $E$, e não $E$ & 2 & 0,207 \\
\hline 72 & $\underline{\text { sintagma port. }}+E$ & 1 & 0,103 \\
\hline 73 & def. port. $E$ & 1 & 0,103 \\
\hline 74 & E & 2 & 0,207 \\
\hline 75 & $\underline{\text { sintagma "E + port." (def. port.) }}$ & 1 & 0,103 \\
\hline 76 & $\underline{\text { sintagma "E" + port. (def. port.) }}$ & 1 & 0,103 \\
\hline 77 & $\underline{\text { sintagma } E+\text { port. } \text { (def. port.) }}$ & 1 & 0,103 \\
\hline 78 & $\underline{\text { sintagma port. }+\mathrm{de}+E}$ & 1 & 0,103 \\
\hline 79 & E ou tradução. def. port. & 1 & 0,103 \\
\hline 80 & def. port., $E$, & 1 & 0,103 \\
\hline
\end{tabular}




\begin{tabular}{|c|c|c|c|}
\hline $\mathbf{N}^{\underline{\mathbf{o}}}$ & Tipos & $\begin{array}{l}\text { Número de } \\
\text { ocorrências }\end{array}$ & $\begin{array}{c}\% \text { de } \\
\text { ocorrências }\end{array}$ \\
\hline 81 & E: Fazer "E" significa def. port. & 1 & 0,103 \\
\hline 82 & E: def. port. & 1 & 0,103 \\
\hline 83 & "E": def. port. & 1 & 0,103 \\
\hline 84 & E sigla: (E por extenso): def. port. & 1 & 0,103 \\
\hline 85 & E def. port. $-E-\underline{\text { def. port. }}$ & 1 & 0,103 \\
\hline 86 & E def. port., o E. & 1 & 0,103 \\
\hline 87 & E & 2 & 0,207 \\
\hline 88 & $E-$ def. port. & 4 & 0,415 \\
\hline 89 & "E" def. port. & 3 & 0,311 \\
\hline 90 & E def. port. Ou seja & 1 & 0,103 \\
\hline 91 & E def. port. & 7 & 0,727 \\
\hline 92 & "E" & 144 & 14,968 \\
\hline 93 & tradução (“E”) & 1 & 0,103 \\
\hline 94 & "E", tradução & 1 & 0,103 \\
\hline 95 & 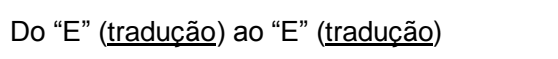 & 1 & 0,103 \\
\hline 96 & "E" tradução def. port. & 1 & 0,103 \\
\hline 97 & "E" [tradução] é def. port. & 1 & 0,103 \\
\hline 98 & "E" (tradução) def. port. & 1 & 0,103 \\
\hline 99 & "E" (吕adução) & 73 & 7,588 \\
\hline 100 & $E$ (tradução), agora rebatizado "E" (E sigla) & 1 & 0,103 \\
\hline 101 & "E" [def. port.] & 1 & 0,103 \\
\hline
\end{tabular}




\begin{tabular}{|c|c|c|c|}
\hline $\mathbf{N}^{\mathbf{o}}$ & Tipos & $\begin{array}{l}\text { Número de } \\
\text { ocorrências }\end{array}$ & $\begin{array}{c}\% \text { de } \\
\text { ocorrências }\end{array}$ \\
\hline 102 & "E" como tradução & 1 & 0,103 \\
\hline 103 & "E" espécie de tradução & 1 & 0,103 \\
\hline 104 & ( $E+$ port. $)$ & 1 & 0,103 \\
\hline 105 & def. port. (“E”) & 37 & 3,846 \\
\hline 106 & (“E”) & 1 & 0,103 \\
\hline 107 & "E", "tradução" & 1 & 0,103 \\
\hline 108 & E sigla (E por extenso) def. port. & 1 & 0,103 \\
\hline 109 & $(E+$ port. $)$ & 2 & 0,207 \\
\hline 110 & (E) & 7 & 0,727 \\
\hline 111 & E & 190 & 19,750 \\
\hline 112 & "E" & 1 & 0,103 \\
\hline 113 & (E, def. port.) & 1 & 0,103 \\
\hline 114 & "E" (há um livro célebre com esse título) & 1 & 0,103 \\
\hline 115 & inventaram a palavra "E" & 1 & 0,103 \\
\hline 116 & "E", isto é, def. port. & 5 & 0,519 \\
\hline 117 & E (citados acima neste artigo) & 1 & 0,103 \\
\hline 118 & "E" (jargão diplomático para documento oficioso) & 2 & 0,207 \\
\hline 119 & mais conhecido como "E" & 1 & 0,103 \\
\hline 120 & "port." ("E", na expressão em inglês) & 1 & 0,103 \\
\hline 121 & no chamado "E" (def. port.) & 1 & 0,103 \\
\hline 122 & no jargão do mercado se chama "E" & 1 & 0,103 \\
\hline
\end{tabular}




\begin{tabular}{|c|c|c|c|}
\hline $\mathbf{N}^{\mathbf{o}}$ & Tipos & $\begin{array}{l}\text { Número de } \\
\text { ocorrências }\end{array}$ & $\begin{array}{c}\% \text { de } \\
\text { ocorrências }\end{array}$ \\
\hline 123 & no jargão do mercado seria um " $E$ " — traduç̃o & 1 & 0,103 \\
\hline 124 & $\begin{array}{l}\text { que o jargão financeiro internacional chama de "E", ou } \\
\text { seja, def. port. }\end{array}$ & 1 & 0,103 \\
\hline 125 & no jargão econômico, se designa como "E" & 1 & 0,103 \\
\hline 126 & no que os economistas chamam de "E" & 1 & 0,103 \\
\hline 127 & "E" (nome dado a def. port. $)$ & 2 & 0,207 \\
\hline 128 & def. port., o chamado "E" & 4 & 0,415 \\
\hline 129 & (o chamado E, ou E sigla) & 1 & 0,103 \\
\hline 130 & def. port. (o chamado E) & 1 & 0,103 \\
\hline 131 & foi batizado de "E" & 1 & 0,103 \\
\hline 132 & o chamado " $E "$ " def. port. & 1 & 0,103 \\
\hline 133 & o chamado "E" (tradução, literalmente) & 1 & 0,103 \\
\hline 134 & o chamado "E", ou seja, def. port. & 1 & 0,103 \\
\hline 135 & o clássico E & 1 & 0,103 \\
\hline 136 & o conceito de "E": def. port. & 1 & 0,103 \\
\hline 137 & E [traducão] & 2 & 0,207 \\
\hline 138 & "E" ("tradução") & 1 & 0,103 \\
\hline 139 & "E" (ou tradução) & 1 & 0,103 \\
\hline 140 & E (tradução) & 22 & 2,286 \\
\hline 141 & "port." (“E”) & 1 & 0,103 \\
\hline 142 & port. ("E") & 1 & 0,103 \\
\hline 143 & (o famoso $E$ ) & 1 & 0,103 \\
\hline
\end{tabular}




\begin{tabular}{|c|c|c|c|}
\hline $\mathbf{N}^{\mathbf{o}}$ & Tipos & $\begin{array}{l}\text { Número de } \\
\text { ocorrências }\end{array}$ & $\begin{array}{c}\% \text { de } \\
\text { ocorrências }\end{array}$ \\
\hline 144 & a antiga & 1 & 0,103 \\
\hline 145 & "E", def. port. & 1 & 0,103 \\
\hline 146 & $\underline{\text { sintagma port. }}+\mathrm{E}$ & 1 & 0,103 \\
\hline 147 & o mecanismo do $\mathrm{E}$ & 1 & 0,103 \\
\hline 148 & sistema chamado "E" & 1 & 0,103 \\
\hline 149 & o mecanismo chamado "E" — def. port. & 1 & 0,103 \\
\hline 150 & o mecanismo denominado "E" (tradução) & 1 & 0,103 \\
\hline 151 & def. port. (o mercado conhece como "E") & 1 & 0,103 \\
\hline 152 & o que a gente chama em inglês de "E" & 1 & 0,103 \\
\hline 153 & o que chama de E "port.": def. port. & 1 & 0,103 \\
\hline 154 & def. port. (o que os economistas chamam de E) & 1 & 0,103 \\
\hline 155 & o que os economistas chamam de "E" & 1 & 0,103 \\
\hline 156 & os especialistas chamam de "E" & 1 & 0,103 \\
\hline 157 & o que chamamos o "E" & 1 & 0,103 \\
\hline 158 & o que se conhece nos EUA como "E" (tradução) & 1 & 0,103 \\
\hline 159 & E (o que significa def. port.) & 1 & 0,103 \\
\hline 160 & o que tem sido chamado de $\mathrm{E}$ é def. port. & 1 & 0,103 \\
\hline 161 & E. O termo em inglês está sendo usado & 1 & 0,103 \\
\hline 162 & "port." ou "E" & 1 & 0,103 \\
\hline 163 & o(s) chamado(s) "E"(tradução) & 3 & 0,311 \\
\hline 164 & port. (os chamados E) & 1 & 0,311 \\
\hline
\end{tabular}




\begin{tabular}{|c|c|c|c|}
\hline $\mathbf{N}^{\mathbf{o}}$ & Tipos & $\begin{array}{l}\text { Número de } \\
\text { ocorrências }\end{array}$ & $\begin{array}{c}\% \text { de } \\
\text { ocorrências }\end{array}$ \\
\hline 165 & "E" def. port. Literalmente significando & 1 & 0,103 \\
\hline 166 & "E"- ou E sigla (por extenso) & 1 & 0,103 \\
\hline 167 & o chamado "E" & 1 & 0,103 \\
\hline 168 & (E, ou E sigla) & 1 & 0,103 \\
\hline 169 & é o chamado "E", def. port. & 1 & 0,103 \\
\hline 170 & é o chamado "E". def. port. & 1 & 0,103 \\
\hline 171 & tradução (o chamado "E") & 1 & 0,103 \\
\hline 172 & o chamado "E", def. port. & 1 & 0,103 \\
\hline 173 & tradução,o chamado "E" & 1 & 0,103 \\
\hline 174 & “E”, ou tradução & 1 & 0,103 \\
\hline 175 & $\mathrm{E}$, onde def. port. & 1 & 0,103 \\
\hline 176 & $E$, ou tradução, de acordo com o jargão local & 1 & 0,103 \\
\hline 177 & os conhecidos port. E & 1 & 0,103 \\
\hline 178 & os iniciados chamam de $\mathrm{E}$ & 1 & 0,103 \\
\hline 179 & o mercado de $\mathrm{E}$ & 1 & 0,103 \\
\hline 180 & "E" - ou tradução & 1 & 0,103 \\
\hline 181 & $\mathrm{E}$, ou tradução & 2 & 0,207 \\
\hline 182 & "E" ou tradução & 2 & 0,207 \\
\hline 183 & "E". "E" def. port. & 1 & 0,103 \\
\hline 184 & E sigla ou port. & 1 & 0,103 \\
\hline 185 & o chamado "E"- ou sigla (E por extenso) & 1 & 0,103 \\
\hline
\end{tabular}




\begin{tabular}{|c|c|c|c|}
\hline $\mathbf{N}^{\mathbf{o}}$ & Tipos & $\begin{array}{l}\text { Número de } \\
\text { ocorrências }\end{array}$ & $\begin{array}{c}\% \text { de } \\
\text { ocorrências }\end{array}$ \\
\hline 186 & $\begin{array}{l}\text { conhecido como port. (E sigla pelas iniciais em inglês), ou } \\
\text { "E" }\end{array}$ & 1 & 0,103 \\
\hline 187 & "E" - ou seja, def. port. & 1 & 0,103 \\
\hline 188 & $\mathrm{E}-$ ou seja, def. port. & 1 & 0,103 \\
\hline 189 & "E", ou seja, def. port. & 3 & 0,310 \\
\hline 190 & o chamado "E",ou seja, def. port. & 1 & 0,207 \\
\hline 191 & "E” (ou seja, def. port.) & 1 & 0,103 \\
\hline 192 & A sigla em inglês é sigla de "E", ou seja, def. port. & 1 & 0,103 \\
\hline 193 & E port. (ou seja, def. port.) & 1 & 0,103 \\
\hline 194 & def. port., ou "E" & 1 & 0,103 \\
\hline 195 & “E” (palavra inglesa que significa tradução) & 1 & 0,103 \\
\hline 196 & — prática chamada de $\mathrm{E}$ - & 1 & 0,103 \\
\hline 197 & prática conhecida como "E" & 1 & 0,103 \\
\hline 198 & são chamados de "E" (expressão em inglês para port.) & 1 & 0,103 \\
\hline 199 & E sigla são def. port. & 1 & 0,103 \\
\hline 200 & $E(E \underline{\text { sigla }}$ - $\underline{\text { traducãa }})$ & 2 & 0,207 \\
\hline 201 & E sigla- E por extenso, def. port. & 1 & 0,103 \\
\hline 202 & $E \underline{\text { sigla }}-E$ por extenso - Def. port. & 1 & 0,103 \\
\hline 203 & E (Epor extenso, def. port.) & 1 & 0,103 \\
\hline 204 & E sigla ("E") & 1 & 0,103 \\
\hline 205 & o chamado E sigla ("E por extenso") ou def. port. & 1 & 0,103 \\
\hline 206 & E sigla (E por extenso) & 22 & 2,286 \\
\hline
\end{tabular}




\begin{tabular}{|c|c|c|c|}
\hline $\mathbf{N}^{\mathbf{0}}$ & Tipos & $\begin{array}{l}\text { Número de } \\
\text { ocorrências }\end{array}$ & $\begin{array}{c}\% \text { de } \\
\text { ocorrências }\end{array}$ \\
\hline 207 & E sigla (port. Por extenso) & 1 & 0,103 \\
\hline 208 & sigla de (“E”) & 1 & 0,103 \\
\hline 209 & port. por extenso (E sigla $-E$ por extenso) & 1 & 0,103 \\
\hline 210 & $E$ sigla, a sigla em inglês (E) & 1 & 0,103 \\
\hline 211 & tradução, o chamado "E" & 1 & 0,103 \\
\hline 212 & E sigla (sigla em inglês de E, ou tradução) & 1 & 0,103 \\
\hline 213 & $\mathrm{E}$ (E sigla, def. port.) & 2 & 0,207 \\
\hline 214 & $E \underline{\text { sigla }}-E$ & 1 & 0,103 \\
\hline 215 & $\mathrm{E}, \mathrm{O}$ E sigla & 1 & 0,103 \\
\hline 216 & tradução $E(E \underline{\text { sigla }})$ & 1 & 0,103 \\
\hline 217 & $\begin{array}{l}\text { o conceito de "E". Significa def. port.1 e, numa tradução } \\
\text { mais ousada, def. port.2 }\end{array}$ & 1 & 0,103 \\
\hline 218 & "E". port. significam, literalmente, "tradução" & 1 & 0,103 \\
\hline 219 & def. port. ... E & 1 & 0,103 \\
\hline 220 & tradução (também chamado de "E") & 1 & 0,103 \\
\hline 221 & tradução (também conhecida como“E”) & 1 & 0,103 \\
\hline 222 & def. port. Também conhecidos por $\mathbf{E}$ & 1 & 0,103 \\
\hline 223 & E sigla (E por extenso), def. port. & 1 & 0,103 \\
\hline 224 & $\begin{array}{l}\text { tem sido chamado de "port.", adaptação da palavra } \\
\text { francesa } E\end{array}$ & 1 & 0,103 \\
\hline 225 & "E" (E sigla) & 1 & 0,103 \\
\hline 226 & $\mathrm{E}$ (E sigla) & 1 & 0,103 \\
\hline
\end{tabular}




\begin{tabular}{|c|l|c|c|}
\hline $\mathbf{N}$ Tipos & \multicolumn{1}{|c|}{$\begin{array}{c}\text { Número de } \\
\text { ocorrências }\end{array}$} & $\begin{array}{c}\text { \% de } \\
\text { ocorrências }\end{array}$ \\
\hline 227 & tradicional e conhecido "E", ou seja, traducão & 1 & 0,103 \\
\hline 228 & o mecanismo chamado "E" (tradução, em tradução livre) & 1 & 0,103 \\
\hline 229 & E-um termo em inglês para designar tradução & 1 & 0,103 \\
\hline
\end{tabular}

\subsection{Tradução dos Estrangeirismos}

Às vezes, o estrangeirismo é acompanhado de tradução. Este fato assinala a consciência, por parte do emissor, de que o termo estrangeiro é desconhecido pelo receptor da mensagem. A tradução é geralmente efetuada depois do termo estrangeiro.

Além de elementos tradutórios, elementos de outras línguas são também explicados por um termo ou uma paráfrase do português, lemos em Alves (1988:8). Mais raramente, o termo estrangeiro explica o termo ou paráfrase portuguesa, prossegue Alves (1988:9), a exemplo de como dizem os franceses.

Rey-Debove (apud Alves 1984(1):99) refere-se ao uso do estrangeirismo como signo autônimo quando intermediado por verbos metalingüísticos como chamar-se ou designar. A conotação autonímica do estrangeirismo ocorre quando o elemento do código estrangeiro é empregado simultaneamente com a unidade lexical pertencente ao código vernáculo, sem a intermediação de verbos metalingüísticos. É o uso de sinônimos (entre os dois códigos), formas perifrásticas ou definicionais que tornam o termo estrangeiro conotativamente autonímico.

O discurso estrangeiro reportado não aparece jamais em uma situação de monolingüismo, pois, para se conservar este discurso e reportá-lo fielmente, é preciso denominá-lo e para que se cumpra a citação, é preciso um interlocutor que também o denomina. Diz Rey-Debove (1978:222) que, neste caso, estamos em situação de bilingüismo determinado. 
Na prática, uma sequiência estrangeira não será considerada desviante: ela representa uma outra norma. O leitor da área econômica, por exemplo, admite o surgimento de um termo estrangeiro no texto.

A tradução é onipresente em textos científicos, técnicos ou comerciais, a ponto de o leitor que lê um texto julgar que tal texto foi inicialmente escrito em sua língua. Lavault (2001:887) nos diz que em todos os textos em que a função comunicativa é prioritária, a transparência, bem como a descrição que a acompanha, é o reconhecimento de uma tradução bem sucedida. Do ponto de vista dos editores, revisores e clientes em geral, a tradução está “correta ou não" (sendo o critério a correção da língua-alvo), "passa ou não passa", "funciona ou não funciona", e isto ocorre no âmbito da metalinguagem pertinente: uma metalinguagem que se refere ao resultado satisfatório, à aceitação da comunicação e à adequação do produto às exigências do interessado na obra. $\mathrm{O}$ número de livros que tratam da tradução pragmática (que representa em torno de $90 \%$ do volume mundial traduzido) é revelador: "não se comenta" cada tradução. As únicas obras que "comentam" e são portadoras de uma metalinguagem específica são os manuais, pouco numerosos em relação à massa de textos traduzidos, que abordam esta atividade sob o ângulo didático.

Lavault (2001:888), ao assinalar a falta de um estudo sistemático sobre a metalinguagem da tradução, embora os escritos sejam de uma grande diversidade, enumera algumas características da metalinguagem próprias da tradução. Simplificando a categorização proposta por Steiner (1978:224), distingue quatro categorias de discursos sobre a tradução:

1) Um discurso pragmático e didático que, na maior parte das vezes, nasce da necessidade de justificar uma prática e que se pode aplicar a qualquer tipo de texto: aparece nos prefácios das traduções, nos tratados de "como traduzir bem" - é o discurso dos tradutores;

2) Um discurso filosófico que coloca a tradução em termos de hermenêutica ou de poética e que pode chegar mesmo a questionar a natureza da tradução - é o discurso de autores de orientação filosófica, literária ou lingüística; 
3) Um discurso científico sustentado pelos pesquisadores dos softwares de tradução que se apóia sobre a lógica formal e nas abordagens lingüísticas calcadas no tratamento automático das línguas - é o discurso dos lingüistas de orientação gerativista ou transformacional e, também hoje, os discursos da informática envolvendo as "indústrias de língua". Este discurso, informa-nos Lavault, é geralmente mal compreendido pelos tradutores;

4) Um discurso pedagógico herdado do ensino das letras clássicas e que decorre essencialmente do exercício da versão: é um discurso docente que tem da tradução a experiência da versão e de temas universitários. Este discurso desenvolve sua própria terminologia, com termos como barbarismo, solecismo, decalque, anglicismo etc., que reflete uma avaliação sob o ponto de vista de erros de tradução e de descuidos da língua (domínio precário da língua-alvo, ou língua-alvo pervertida pela atividade de tradução). É um metadiscurso negativo, marcado negativamente, uma metalinguagem mais da versão do que da tradução (que, além disso, contrasta com o metadiscurso pragmático da tradução, que se coloca positivo e formador).

A metalinguagem da tradução se constrói principalmente em torno da noção de "fidelidade". Ocorre que fidelidade é noção sutil, suscetível de múltiplas interpretações: fidelidade a quê? Uma boa tradução é sempre fiel, claro, mas fiel a quê? À palavra, ao sentido, ao autor? À língua-fonte, ao estilo, ao leitor? Tantas fidelidades implicam tantas infidelidades! Seria preciso especificar a fidelidade que se busca, talvez, em cada caso, em cada tipo de texto, em cada intenção tradutória. Toda a terminologia tradutológica se articula em torno da noção de fidelidade, toda teoria, prática ou estratégia de tradução se posiciona sobre um eixo em que se enfrentam os pólos opostos da fidelidade: de um lado, a tangibilidade das palavras e do estilo, a personalidade de um autor, mas também a forte marca de uma língua- e de uma cultura-fontes; de outro, a invariância do significado, a expectativa do leitor e o apelo sedutor de uma língua- e de uma cultura-alvos.

A busca de uma metalinguagem precisa permite a conceitualização do domínio por seus praticantes e um discurso teórico indispensável à boa compreensão da atividade. 
Tratando-se, a tradução, de uma atividade de transferência lingüística complexa, a metalinguagem permite a esquematização do processo, sua decomposição em diferentes fases, a classificação em diversos procedimentos e a seleção gradual das dificuldades.

No corpus analisado, de maneira geral, a tradução ocorre após os registros do estrangeirismo:

- [ID: 2832] - Apesar do recente otimismo que atingiu os mercados com o fim do processo eleitoral no Brasil, um quadro extremamente negativo do país está sendo exposto por companhias estrangeiras na SEC (<Securities and Exchange Commission>), a comissão de valores mobiliários americana. [Marcio Aith] - (FSP, 17-1 1-02, p. B.1, c. 1)

embora não raro também apareça antes:

[ID: 2095] - "Isso se deve em parte a mecanismos protecionistas como as medidas <antidumping>, e os direitos compensatórios, assim como os subsídios das economias avançadas." - (FSP, 29-04-01, p. B.4, c. 6)

[ID: 1] - Entretanto, isto não ocorreu no mês de dezembro com as taxas básicas de juros, como as taxas de financiamento de títulos públicos federais e DI-over, cujas variações são fortemente condicionadas pelo comportamento do Banco Central no mercado monetário. Essas taxas, bem como as taxas do mercado de empréstimos de curtíssimo prazo às empresas (<hot money>), apresentaram contínua tendência de queda ao longo de todo o mês de dezembro. - (CE, 02-95, p. 30, c. 1)

Freqüentemente, a forma de apresentação do estrangeirismo consiste na simples inserção direta da tradução do vocábulo estrangeiro, sem qualquer menção ou conectivo.

Outras vezes, o emissor recorre a meios metalingüísticos, como, nos exemplos abaixo:

1. Alguns termos nem têm tradução, expressam um conceito: o emissor refere-se a conceitos, como se esses não fossem suscetíveis de tradução. A referência à tradução aqui aparece metalingüisticamente e, de alguma forma, desvalorizando a possibilidade de tradução. Provavelmente quer se referir a uma certa "internacionalidade" do termo disclosure e reafirmar sua origem (e superioridade) 
anglo-saxã. Conclui, negando a possibilidade da tradução plena: transparência não contém, sugere ele implicitamente, todos os semas inerentes a disclosure:

- [ID: 1503] - Misumi trabalha em um banco britânico e diz que "tem de haver bom senso no uso de termos estrangeiros". Segundo ele, os especialistas do mercado financeiro estudam os mercados de países mais desenvolvidos, especialmente o dos EUA, e acabam adotando sua terminologia. "Alguns termos nem têm tradução, expressam um conceito. É o caso de <'disclosure'>, que é a política de uma empresa de bem informar o mercado", comenta ele. "Poderia ser substituído por transparência, mas não resolveria". - (FSP, 13-11-00, p. F.7, c. 3-4)

2. Nos exemplos a seguir, a equivalência é admitida por meio de ou. A tradução vem após a conjunção $o u$, precedida de vírgula ou travessão.

- ou, tradução

- $\quad$ ou - tradução

Nestes casos, parece haver uma relação simétrica, de igualdade entre os termos das duas línguas. $\mathrm{O}$ emissor prescinde de qualquer recurso metalingüístico e introduz "naturalmente" a tradução, como se ambas as línguas estivessem em um mesmo plano.

- [ID: 177] - De fato, o mercado de <commercial papers>, ou notas promissórias, a maior fonte de financiamento de curto prazo para as corporações americanas com as melhores classificações, exclui parcial ou totalmente uma série de grandes tomadores de empréstimos, como DaimlerChrysler AG, Lucent Technologies Inc. e Goodyear Tire \& Rubber Co. - (ESP, 02-05-01, p. B.7, c. 1)

- [ID: 389] - Segundo ele, até agora, 40 bancos já optaram pelos <"exit bonds"> - ou bônus de saída para aqueles credores que trocarem suas dívidas antigas por um título de longo prazo, garantido pelo governo brasileiro -, o que equivale a uma subscrição no valor de US $\$ 500$ milhões. Para Mailson, esta opção será um "sucesso". - (FSP, 09-08-88, p. B.8, c. 2-4)

- [ID: 924] - JOHN KENNETH GALBRAITH: É um processo de especulação natural. Os preços das ações sobem, as pessoas ficam atraídas por isso, querem ganhar dinheiro. Então os preços sobem mais, justificando as expectativas dos investidores. Esse processo acontece sem que haja relação entre os preços das ações e a economia, 
até o dia de um grande <crash>, ou uma grande crise. Então, todas as pessoas que estavam no mercado acionário tentam achar uma explicação racional para a crise. - (G, 02-11-97, p. 39, c. 2)

- [ID: 1811] - Os juros são cobrados nos empréstimos <"overnight"> ou taxa de curto prazo. - (FSP, 26-03-95, p. ?, c. 2)

- [ID: 1898] - É óbvio que para nós o trunfo principal é o tamanho atual e o potencial de crescimento do mercado interno. É isso que nas negociações comerciais se denomina <"market power"> ou poder de mercado: a capacidade de dosar o acesso dos outros ao próprio mercado em função das concessões obtidas para a nossa penetração nos mercados alheios. Isso vale para os investimentos e para o comércio, em separado, ou, melhor ainda, para os investimentos casados ao comércio exterior e a seu serviço. - (FSP, 13-06-99, p. 2.2, c. 4)

3. Significa, ..., e, numa tradução mais ousada: o emissor reconhece a capacidade que a tradução oferece de "graduar" a intensidade do termo. Traduz, define com um verbo metalingüístico (significar) e se permite tradução mais ousada.

- [ID: 1558] - O Banco Mundial (Bird) acaba de divulgar seu relatório sobre a pobreza. Há uma inovação política e metodológica: os técnicos resolveram ouvir "a voz dos pobres". E colocaram em primeiro plano o conceito de <"empowerment">. Significa distribuir poder, descentralizar e, numa tradução mais ousada, autogestão. Nora Lustig, economista, foi chamada para coordenar a fase final de elaboração do trabalho. - (FSP, 17-09-00, p. B.2, c. 1)

4. em tradução livre: a advertência de tradução livre parece liberar o emissor de responsabilidade: faz digressões, com liberdade, em torno do termo. No caso do ID 508, abaixo, a tradução livre não foi suficiente para transmitir a noção desejada. $\mathrm{O}$ emissor reforça com "traduzindo" e reformula a frase:

- [ID: 508] - [...] a autorização congressual para o mecanismo chamado <"fast track"> (via rápida, em tradução livre) só virá acompanhada da exigência da cláusula social. E o <"fast track"> é, segundo o próprio subsecretário, "central para a integração hemisférica". Traduzindo: o <"fast track"> dá ao Executivo mãos livres para 
negociar acordos comerciais, como, no caso hemisférico, a Alca [...] que envolve todos os 34 paises americanos, exceto Cuba. - (FSP, 02-02-97, p. 1, c. 6)

5. numa tradução livre seria algo como: essa fórmula de explicitação confere ao emissor a possibilidade de tradução aproximada; ele fica autorizado a descartar qualquer busca de precisão e se libera para inserir interpretação subjetiva:

- [ID: 4530] - O processo que levou a Telecom Italia a sair da Brasil Telecom é um exemplo. Embora as partes não comentem detalhes da operação, um dos pontos acertados, segundo uma das pessoas envolvidas no acordo, foi que o lote de $19 \%$ do capital do qual os italianos abriram mão ficará aos cuidados de uma figura jurídica conhecida no direito anglo-saxão como <trustee>. O <trustee>, que numa tradução livre seria algo como um administrador de confiança, é transformado, por contrato, no dono do bem a ser administrado, seguindo as orientações do proprietário. [Consuelo Dieguez] - (Ex, 18-09-02, p. 72, c. 1)

6. Literalmente: Aqui a intenção parece ser de concisão e de precisão. Pretende-se a absoluta equivalência.

- [ID: 508] - Mas, agora, fatia significativa do Congresso norte-americano quer vincular a concessão do chamado <"fast track"> (via rápida, literalmente) à cláusula social. O <"fast track"> é um mecanismo pelo qual o Executivo fica autorizado a negociar acordos comerciais (como a Alca) para ser depois aprovado ou rejeitado em bloco pelo Congresso. Ora, se o <"fast track">, que já não é fácil de obter, sair vinculado à cláusula social, Aí é que a negociação pára. - (FSP, 11-05-97, p. 2.5, c. 1 3)

7. Ao pé da letra. Tanto literalmente (do ID:508, acima) quanto ao pé da letra, no exemplo a seguir, são precauções que pretendem absoluta fidelidade, mostram a intenção de se resguardar de qualquer imprecisão (evidentemente, para os emissores de mensagem que crêem nessa possibilidade tradutória):

- [ID: 145] - [...] Nem sequer é conhecido na praça como uma modalidade tradicional de seguro, embora ofereça proteção contra oscilações imprevistas no câmbio. É encontrado nos principais bancos e corretoras de commodities do país e tem atraído um número crescente de empresas, principalmente depois da 
implantação do real. Para contratá-la basta pedir pelas operações conhecidas no mercado financeiro pelo nome de <hedge>. Ao pé da letra, <hedge> significa proteção, em inglês. São operações feitas com o uso do que se convencionou chamar de derivativos, a última moda no mercado financeiro mundial em termos de instrumentos de proteção de ativos e passivos contra imprevistos. - (Ex, 21-12-94, p. 106, c. 1)

8. Diferenças de tradução: Antes que haja uma integração do estrangeirismo e o emissor possa recorrer a dicionários ou antes que o termo adquira uma tradução consentida, o termo fica sujeito às mais variadas traduções que podem refletir sutis (e às vezes nem tão sutis) diferenças semânticas e de registro.

É o que ocorre com default, que recebeu traduções as mais diversas, que vão do técnico ao pejorativo: não pagamento de dívida no prazo, quebra, moratória, calote. Tudo para o mesmo default...

- [ID: 250] - Ela afirmou que em um processo de <"default"> (não pagamento de dívida no prazo), há duas hipóteses. Uma seria o credor - no caso, o BNDES "graciosamente" fazer novo empréstimo ou então fazer uso das garantias. "É inviável supor que o Estado brasileiro vai arcar com mais um custo. Tudo indica que a AES não tenha condições de honrar mais um empréstimo", disse. - (FSP, 27-02-03, p. B.5, c. 2)

- [ID: 250] - "Para Meirelles, a principal delas diz respeito à saúde do sistema financeiro, "já ajustada no primeiro período do Real" (leia-se Proer). Com ele concorda o economista José Alexandre Scheinkman, para quem os bancos estavam "hedgeados" (protegidos) e não sofreram com a desvalorização. Ao contrário, ganharam. "Como quem vendeu o hedge (proteção; no caso, títulos com correção cambial) foi o governo, a crise só viria se houvesse <default> (quebra) do próprio governo", declara. " - (FSP, 27-06-99, p. E.4, c. 2-3)

- [ID: 250] - A puxada dos juros de $29 \%$ para $39 \%$ ao ano agravou essa expectativa, lembra ele. Agora, com a taxa parada, o medo de um <"default"> (moratória) é menor. Se os juros subirem, o temor certamente volta, argumenta o economista. (FSP, 28-02-99, p. 2.8, c. 4) 
- [ID: 250] - Diferentes vilões abalaram o mercado neste ano: crise energética, elevação dos juros, valorização do dólar e aumento do temor de <"default"> (calote) da Argentina. - (FSP, 22-07-01, p. B.10, c. 1)

\subsection{Análises de Algumas Formas de Apresentação}

\section{1) Integração dos Estrangeirismos através dos recursos gráficos}

Os recursos gráficos são praticamente específicos da língua escrita sem correspondência precisa na língua falada. Segundo Kocourek (1991:98), a linguagem escrita apresenta o conteúdo técnico-científico sob uma forma suficientemente permanente, estável e disponível para permitir o estudo e a reflexão detalhada, prolongada e repetida. O caráter visual da escrita permite a contemplação quase simultânea de segmentos de conteúdo. As operações cognitivas ficam facilitadas, independentes do hic et nunc da linguagem falada e liberadas de certas exigências incômodas que a linguagem falada impõe à compreensão e à memória do receptor da mensagem.

Alves (1988:12), diz-nos que a conotação autonímica do termo estrangeiro, a que se refere Rey-Debove, revela-se também com os estrangeirismos que, embora empregados sem a concorrência do termo vernáculo, aparecem com marcas gráficas, maiúsculas e grifo. O mesmo termo estrangeiro, prossegue a autora, pode ser empregado em diferentes contextos com distintas marcas gráficas. Por exemplo, (maiúsculas):

- [ID: 146] - O mercado futuro de câmbio comercial da BM\&F movimentou $R \$ 8,8$ bilhões por dia, no ano passado. O futuro de juros (DI) movimentou R\$13,4 bilhões por dia. E o mercado de <"SWAPS"> [troca de empréstimos entre duas partes para proteção contra eventuais perdas] - que envolve trocas de posições entre juros pré e pós-fixados e entre juros e dólares - girou $R \$ 8,3$ bilhões por dia. Os três somaram os $R \$$ 30,5 bilhões citados no início deste texto. - (FSP, 20-05-99, p. E.1, c. 3)

As aspas constituem um dos procedimentos formais para marcar a capacidade da linguagem escrita de se referir a si mesma, à própria enunciação. Elas indicam os campos de 
pertencimentos do autor e do leitor, criando um universo de cumplicidades ou de exclusão (Marinho,2003).

As aspas ocorrem com freqüência quando os estrangeirismos já estão integrados ou estão se integrando. É como se houvesse uma sequiência, conforme o grau de penetração que o estrangeirismo vai adquirindo, :

\section{"E” com tradução $\rightarrow$ "E" $\rightarrow \mathrm{E}$}

ou seja, o estrangeirismo aparece primeiro com aspas e tradução, numa fase posterior com aspas (eventualmente com tradução), e, finalmente, sem aspas, conforme mostram exemplos abaixo:

- [ID: 1] - Segundo Mailson, juros na casa dos $200 \%$ reais ao ano - caso de "<hot money>" (empréstimos por um dia para empresas) - são "incompatíveis com qualquer tipo de atividade econômica até mesmo o lenocínio". - (FSP, 04-01-91, p. B.2, c. 2)

- [ID: 322] - Cerca de $70 \%$ das empresas consideradas de primeira linha têm recibos de ações negociados no exterior, os ADRs (<American Depositary Receipts>), o que inibe a migração de investidores para o Brasil. "Por que o estrangeiro viria para a Bovespa, se as nossas 'blue chips' (ações de maior liquidez) já são negociadas no exterior?", questiona Décio Pereira Filho, da Socopa. - (FSP, 31-01-00, p. 2.2, c. 3)

- [ID: 99] - As ações mais negociadas em Bolsa hoje podem não estar entre as mais líquidas daqui a dez anos. Algumas ações que eram consideradas <"blue chips"> no mercado acionário na década de 80 e início da década de 90, por exemplo, perderam volume financeiro e valor ao longo dos anos. - (FSP, 09-10-00, p. F.6, c. 1)

- [ID: 1546] - A mesma inconsistência surge nas análises do choque petrolífero. Fala-se numa economia mundial em fase de <"boom"> com uma demanda pressionando os estoques muito baixos (nos EUA) de petróleo. Mas nada parece mais distante de uma descrição da economia mundial hoje do que a palavra <"boom">. A tendência é de desaquecimento e, se essa desaceleração ainda não é suficientemente forte, o mais provável é que os bancos centrais da União Européia, EUA e Japão continuem a apostar contra a inflação subindo as Suas taxas normais de juros. - (FSP, 10-09-00, p. B.2, c. 1-2) 
- [ID: 1] - Existe um ponto que incomoda. Uma empresa abre seu capital quando necessita de recursos financeiros duradouros. Loyal money e não <hot money>. Recursos que não têm prazos de resgate e que não fugirão ao primeiro sinal de perigo. - (Ex, 29-03-95, p. 25, c. 2-3

A diminuição da ambigüidade, lembra ainda Kocourek (1991:99), é outra característica da linguagem escrita em relação à falada, ao reduzir a obscuridade, os equívocos que estão sempre ocultos em toda parte, como verdadeiros inimigos invisíveis das línguas. Outra característica da língua escrita é sua potencial internacionalidade. Embora menos internacional do que a linguagem simbólica da ciência, a escrita é menos ligada do que a língua falada à especificidade de uma determinada língua natural, facilitando a unificação científica e técnica internacional. O tipo de recurso gráfico mais freqüente no corpus analisado refere-se aos meios chamados tipográficos.

O itálico serve para marcar uma citação, um estrangeirismo ou uma particularidade semântica:

- [ID: 1] - Quais os resultados dessas medidas? As taxas de juros subiram, principalmente depois da crise mexicana. Na medida do período de novembro a março, as aplicações overnight referenciadas em títulos públicos renderam 2,1\% ao mês, em termos reais, e as cadernetas de poupança, 1,5\%. No lado das aplicações, o retorno real das operações bancárias de curto prazo (<hot money>) aumentou de $3,8 \%$ para $4,4 \%$. Tais rentabilidades elevadas, porém, não foram suficientes para reverter o crescimento da oferta de crédito. - (CE, 06-95, p. 18, c. 2)

- [ID: 1] - Portanto, deflacionadas por uma cesta de índices de inflação (IGP-DI, INPC e IPC-Fipe), as aplicações overnight dos bancos renderam em média 1,7\% em termos reais, em abril, as aplicações em cadernetas de poupança, 1,4\% e os empréstimos bancários de curto prazo (hot money), 3,7\%. - (CE, 07-95, p. 16, c. 3)

O negrito também exprime a ênfase sobre o termo ou a expressão:

- [ID: 1368] - "Como funciona o <'after market'>, o chamado pregão noturno da Bovespa?" (Daniel Silveira, SP) <"After market"> (depois do mercado, em inglês) é a negociação eletrônica diária entre Bovespa (Bolsa de Valores de São Paulo) e 
corretoras que ocorre após o fechamento do pregão tradicional (realizado das $11 \mathrm{~h}$ às 18h). - (FSP, 01-11-99, p. 2.8, c. 1)

- [ID: 145] - <"Hedge">: Fazer <"hedge"> significa contratar uma operação visando neutralizar possíveis perdas em outra. Trata-se de salvaguarda ou proteção contra a flutuação de preços de mercadorias, ações, taxas de câmbio etc. Por exemplo: atuar conjuntamente no mercado de ações e nas Bolsas de Mercadorias como forma de compensação de eventuais prejuízos em alguns desses mercados. - (FSP, $30-04-99$, p. 1.7, c. 1-2)

- [ID: 924] - <Crash> [termo em negrito]- nos períodos em que o preço das ações subiu muito mais que o lucro das empresas, como 1929 ou 1987, houve queda repentina nas Bolsas - <crash> - ou períodos de desvalorização muito longos. No caso do <crash>, pode haver desorganização do mercado, falências de instituições financeiras e empobrecimento de quem investiu em ações. - (FSP, 09-04-00, p. 2.3, gráfico)

- [ID: 1037] - [termo em negrito] <Drawback> Será alargado o prazo para a empresa comprovar a importação de insumos de produtos para a exportação, o <drawback>. Atualmente, ao longo de um período de 180 dias, o empresário tem de apresentar as comprovações a cada 30 dias. Com a mudança, passará a fazer as comprovações mensais após 180 dias. - (FSP, 24-05-99, p. 3.4, c. 7)

As aspas podem ser empregadas, igualmente, para registrar distinções necessárias na analise semântica de unidades lexicais. Quando precedem a indicação de função,diz-nos Laurian (1983:19), mostram claramente que se trata de um termo novo que vai ser traduzido e que se tentará defini-lo. Também são empregadas, afirma Bechara (2001:613), para dar à certa expressão sentido particular (na linguagem falada é em geral proferida com entoação especial), para ressaltar uma expressão dentro do contexto ou para apontar uma palavra como estrangeirismo ou gíria:

- [ID: 1] - Estes dados conduzem à conclusão de que o capital de giro prefixado, antecipando o futuro, estará sempre mais barato que o <"hot money">. - (FSP, $31 / 10 / 93$, p. 2.7, c. 2$)$ 
- [ID: 25] - O ano passado terminou, por exemplo, com uma renda agrícola estimada em $R \$ 15$ bilhões e teve produção da ordem de 80 milhões de toneladas. Nada mal para quem há três anos esteve à beira da falência. São números expressivos que mostram a força do setor, a capacidade do <"agribusiness"> brasileiro de se adaptar e reagir a situações adversas. - (FSP, 02-02-97, p. 2, c. 3)

- [ID: 131] - O artigo 36 tem a função de estimular a repactuação dos contratos já que impede que o credor se remunere pelo resíduo estatístico da inflação, o <"carry over">. - (FSP, 20-03-94, p. 2.12, c. 3)

- [ID: 714] - Na gestão de Armínio (1999-2002), o Banco Central chegou à mesma conclusão em um estudo para investigar as causas do elevado <"spread"> bancário a diferença entre os juros pagos aos poupadores, mais próximos à taxa básica do BC, e os cobrados dos tomadores de empréstimos, que facilmente ultrapassam os $100 \%$ anuais - no Brasil. - (FSP, 28-01-03, p. B.1, c. 1-2)

Kocourek (1991:104) menciona ainda os recursos proporcionados pela espacialização no plano textual. Ela é veículo de segmentação do texto e de valoração de seus componentes. À disposição horizontal ou vertical de listas e quadros, ao branco das alíneas, acreditamos poder acrescentar outra maneira de dar ênfase, quando a produção tipográfica do veículo assim enseja, que consiste em estabelecer um destaque através da cor. Assim, por exemplo, encontramos no nosso corpus, destaques em vermelho:

- [ID: 88] - <Benchmark> - É o indicador que deve ser utilizado como referência para avaliar a performance (o resultado) de um investimento. - (EP, 05-04, p. 2, c. 2)

e destaques em azul:

- [ID: 322] - ADR (<American Depositary Receipt>) Papel emitido e negociado nos Estados Unidos, com lastro em ações de outros países - (FSP, 05-06-00, p. F.2, c. 5); (FSP, 23-08-99, p. 2.2, C. 5); (FSP, 05-06-00, p. F.2, C. 5); (FSP, 09-10-00, p. F2, C. 5); (FSP, 23-10-00, P. F.2, C. 5); (FSP, 05-02-01, P. F.2, c. 5); (FSP, 21-05-01, p. B.4, c. 5, quadro); (FSP, 18-06-01, p. B. 6, C. 5)

O corpus adota o sinal tipográfico conhecido como chevron $(<>)$, para o registro de todos os termos. Os parênteses, freqüentes no corpus, diz-nos Bechara (2001:612), assinalam 
isolamento sintático e semântico mais completo dentro do enunciado, alem de estabelecer maior intimidade entre o autor e o seu leitor. Em geral, a inserção do parêntese é assinalada por uma entonação especial:

- [ID: 633] - "Na crise está ocorrendo o fenômeno clássico da fuga indiferenciada, uma saída desordenada dos países "emergentes" e uma procura crescente por aplicações seguras, especialmente os títulos do Tesouro norte-americano los <Tbonds> já estão a 6,09\% a.a. )." - (FSP, 16-11-97, p. 2.6, c. 1)

- [ID: 2545] - Além das notícias (<clippings> e direto da redação), o portal continua publicando o Marinha Mercante todas às quartas, como já é usual. Portanto, o jornal continua existindo, só que agora na mídia eletrônica, e quando forem edições especiais, circulará dentro do caderno de economia do Estadão. - (ESP, 18-04-01, p. B.21, C. 5)

- [ID: 773] - Os EUA têm a prática de vender produtos em outro mercado abaixo do preço de custo (<dumping>), condenada por Brasil e Japão - (FSP, 28-11-99, especial.4, c. 4)

Aspas e parênteses, não raro, ocorrem de maneira conjugada:

- [ID: 88] - Atento a isso, o Banco Central definiu três categorias para os fundos de renda fixa, que entram em vigor neste mês: os que têm índice de referência de desempenho (<"benchmark">), os alavancados e os não alavancados. O que também deve ser apreciado e tende a aparecer com freqüência nesse ano são as avaliações de risco ("rating") dos fundos, feitas por agências independentes especializadas. São notas dadas para os riscos de crédito e de mercado, de acordo com critérios de cada agência. - (FSP, 03-01-00, p. 2.4, c. 1)

- [ID: 145] - Veja-se, nesse sentido, o exemplo brasileiro, no qual o governo e o Banco Central suportam o ônus de proteger (<"hedge">) o setor privado contra os riscos de mercado e de câmbio - seja por <"hedges"> em moeda estrangeira, seja por obrigações governamentais indexadas às taxas de juros de curto prazo ou à taxa de câmbio. A conseqüência é que os gastos do governo e as taxas de juros são mais altas do que seriam em outras condições, criando, assim, impedimentos naturais a um crescimento mais satisfatório. Pode-se dizer que o Brasil possui um setor privado relativamente "hedged" contra a volatilidade externa, mas paga para isso o preço 
de uma taxa de crescimento mais baixa. (Rubens Ricupero) - (FSP, 11-08-02, p. B.2, C. 4)

- [ID: 146] - Então, foi um passo muito simples e óbvio quando duas empresas, uma inglesa e uma norte-americana, fizeram um acordo para que as moedas de uma ficassem à disposição da outra e vice-versa; houve uma troca ("<swap>") de moedas. Tudo isso foi muito simples, mas foi daí que surgiu a enorme indústria moderna dos "<swaps>", que acabou, no curso de seu crescimento, minando praticamente todos os controles sobre fluxos de divisas, que foram a causa de sua origem. Os "<swaps>" fornecem um exemplo muito claro de como a inovação financeira pode servir para minar a regulamentação opressiva dos governos. - (FSP, 05-07-98, p. 2.2, c. 4-5)

Intimamente ligados aos parênteses pela sua função discursiva, os colchetes são utilizados quando já se acham empregados os parênteses, para introduzirem uma nova inserção. Servem também para assinalar uma intervenção do emissor na mensagem comunicada por outrem. Colchetes praticamente não foram encontrados no corpus.

\section{2) Não-anglicismos}

Segundo Cunha (2003:9), a partir da segunda metade do século XVI e durante todo o século XVII, é o castelhano que fornece ao português boa soma de empréstimos. É o período da dominação espanhola (1580 - 1640). Por essa época, muitos escritores portugueses são bilíngües. Como D. Francisco Manuel de Melo, talvez o mais ilustre de todos eles. Diga-se de passagem, que já antes, em todo o século XVI, o castelhano era cultivado por poetas do porte de Camões, Diogo Bernardes e Pero de Andrade Caminha, entre outros.

De meados do século XVII, durante todo o século XVIII e todo o século XIX é a França que domina o panorama cultural da Europa. Da França partem as novidades que se irradiam por todo o mundo, acompanhadas naturalmente dos vocábulos franceses que as nomeiam. É a época da invasão dos galicismos, tão repudiados pelos puristas de Portugal, do Brasil, da Espanha e dos paises da América Espanhola. 
O século XIX assiste à revolução industrial na Inglaterra e à conseqüente introdução nas línguas da Europa de numerosos anglicismos. A linguagem internacional das ciências (física, química, mineralogia etc.), da política e da administração, entre outras, é enriquecida com vários termos de origem inglesa. $\mathrm{Na}$ atualidade, o processo se aguça com o predomínio e expansão mundial do idioma inglês.

De fato, embora predominem os anglicismos no corpus analisado, encontramos exemplos de estrangeirismo de variadas origens, conforme encontramos nos contextos abaixo,: débâcle, default, laissez-faire, bricolage (galicismos), corralito, trueque megafair, El Niño (espanholismos), ex-ante, expost-facto (latinismos), chaelbols, samurai bonds (do coreano e japonês, respectivamente).

- [ID: 101] - Infelizmente, o que se viu na recente "débâcle" de Wall Street é que tanto os analistas de ações como as firmas de contabilidade e auditoria, sem falar nos <"boards"> das empresas e em seus executivos, com freqüência atraiçoaram a confiança dos acionistas e dos empregados. Não é exagero, assim, sustentar que, longe de demonstrar a prudência usual, muitos dos que formam a opinião de Wall Street revelaram alarmante falta de integridade e espantosos erros de julgamento, sendo este último o caso das agências de avaliação de risco. (Rubens Ricupero) (FSP, 11-08-02, p. B.2, c. 3)

- [ID: 250] - Ela afirmou que em um processo de <"default"> (não pagamento de dívida no prazo), há duas hipóteses. Uma seria o credor - no caso, o BNDES "graciosamente" fazer novo empréstimo ou então fazer uso das garantias. "É inviável supor que o Estado brasileiro vai arcar com mais um custo. Tudo indica que a AES não tenha condições de honrar mais um empréstimo", disse. - (FSP, 27-02-03, p. B.5, C. 2)

- [ID: 1214] - George Soros tocou no mesmo ponto: o de que o mercado não pode regular sozinho o mundo. Em 1997, o financista foi chamado de hipócrita, aqui mesmo em Davos, por ter publicado um artigo sobre as ameaças do capitalismo. Ele criticava a ideologia básica do 'laissez-faire', segundo a qual o livre mercado corrige, por si mesmo, os excessos, e não precisa de interferência dos governos. - (G, 01-02-98, p. 39, c. 31 
- [ID: 4329] - De alguns anos para cá, o antigo "faça você mesmo" ganhou um toque de sofisticação. Ele tem sido chamado de "bricolagem", adaptação da palavra francesa <bricolage>. A essência da atividade entretanto, continua a mesma: é a arte de realizar serviços de marcenaria, reforma, jardinagem e outros por conta própria. - (Ex, 06-02, p. 44, c. 1)

- [ID: 2814] - Em 2002, no auge da crise econômica provocada pela moratória, o governo argentino confiscou os depósitos bancários da população, impondo limites para saques. $O$ <corralito> tirou bilhões de pesos de circulação e, sem dinheiro nas mãos, só restou aos argentinos recorrer ao escambo. - (G, 06-02-05, p. 19, c. 5)

- [ID: 2603] - Cerca de 10 mil pessoas fizeram compras numa <"trueque megafair"> de $1^{\circ}$ de maio, na semana passada, num subúrbio de Buenos Aires. - (ESP, 09-05-01, p. B.20, c. 3)

- [ID: 774] - Para Mário Coelho, da Austin Asis, o impacto do <"El Niño" financeiro> foi menor que o esperado pois grande parte das aplicações dos bancos de investimento foi dirigida às privatizações. - (FSP, 12-04-98, p. 2.2, c. 2)

- [ID: 3650] - Nenhum norte-americano ou europeu procura adivinhar, olhando a "Prime Rate" ou a "Libor" o que é, "ex-ante", taxa real e expectativa de inflação. Apenas os acadêmicos fazem cálculos <"expost-facto">, deflacionando as taxas nominais por algum índice de inflação (claramente explicitado) e chegando à taxa real "ex-post". E as há tantas quantos os índices de inflação disponíveis. - (FSP, 10-0794, p. 2.2, c. 3)

- [ID: 1394] - O modelo de crescimento que transformou a Coréia em "tigre", caracterizado por forte intervencionismo estatal e concentração da economia nos $<$ "chaelbols"> (grandes conglomerados familiares), parecia condenado pela crise de 97/98. - (FSP, 20-02-00, p. 2.6, c. 3)

- [ID: 1283] - Ciente do seu fôlego, a Petrobrás se prepara para mais um round na captação de recursos no exterior. Depois de lançar nos últimos dias <"samurai bonds"> (títulos no mercado japonês), ela tem planos de emitir papéis no mercado americano (os chamados ADRs de nível dois). No rastro dessas emissões, vários bancos estão divulgando a empresa no exterior. BRASílIA. O Governo estuda uma série de medidas, que virão acompanhadas de abertura de mercado brasileiro para 
o capital externo, com o objetivo de reduzir o custo das empresas nacionais de aviação e, ao mesmo tempo, atrair o interesse das companhias estrangeiras. Além da Medida Provisória ampliando de $20 \%$ para $49 \%$ a participação de empreendimentos de outros países nas companhias aéreas brasileiras, a área econômica pretende elevar para até 25 anos o financiamento de aeronaves pelo BNDES, facilitar o processo de reposição de peças por meio de importação e aumentar o prazo do <"leasing"> de aeronaves dos atuais 59 meses para um mínimo de dez anos. - (G, 07-09-97, p. 35, c. 2)

\section{3) Muitas vezes o emissor da mensagem como que pressupõe o conhecimento do estrangeirismo por parte do receptor.}

Em certos contextos o estrangeirismo vem sem qualquer tipo de apresentação, insinuando-se "naturalmente" na frase, sem demonstrar qualquer necessidade de introdução ou justificativa.

Alguns, de fato, já têm credencial para isso: são termos incorporados ao vernáculo, como por exemplo, hot money, boom, cash, e outros constantes dos exemplos a seguir:

- [ID: 1] - [...] No caso das taxas de aplicação e captação bancárias, houve evolução ascendente durante todo o mês, devido a expectativas de alta da inflação, que terminaram por se confirmar, e à antecipação de medidas de contenção do crédito, que ocorreram de fato 19-20 de outubro. Assim, as taxas de $<$ hot money> e CDB abriram o mês em 5,8\% a.m. e 54, 2\% a.a., respectivamente, e fecharam em $6,8 \%$ a $58,1 \%$. - (CE, 01-95, p. 14, c. 1)

- [ID: 1546] - Para o economista-chefe da consultoria norte-americana Global Insight, uma das mais conceituadas do mercado, uma guerra seguida por vitória rápida do exército norte-americano seria capaz de produzir um <boom> no índice de confiança dos consumidores e das empresas. Na seqüência, as economias mundiais terminariam por crescer na esteira dos impactos positivos da aceleração da economia dos Estados Unidos. - (FSP, 16-03-03, p. B.4, c. 1)

- [ID: 141] - Segundo o presidente do BNDES, Edmar Bacha, a desestatização da Vale ocorrerá após um "amplo debate público". Devido a seu tamanho e sua eficiência, a venda da empresa deverá ser cercada de muitos cuidados. Apesar de tudo ainda 
estar no terreno das intenções, o ministro do Planejamento já se manifestou favorável a uma venda $100 \%$ <cash>. "Nenhuma moeda podre será aceita", anunciou Serra. Embora ainda não haja prazos definidos, a conclusão do negócio não deverá ocorrer antes do final de 1996. - (CE, 05-95, p.18, c. 3-4)

Outros, entretanto, vêm "sem qualquer aviso", ou o fazem de maneira precária, utilizando termos em inglês que provavelmente não são de compreensão de um receptor médio na área de economia, como, por exemplo, hard landing, Dutch disease, compliance.

- [ID: 1611 ] - Também existe a possibilidade de uma recessão, de um <hard landing>, mas esse é o cenário menos provável na nossa opinião. No ano passado, apostávamos mais numa recuperação no formato da letra $\vee$. - (FSP, 29-04-01, p. B.4, c. 2)

- [ID: 340] - Há evidência empírica estabelecida de que o déficit público, os termos de troca, a eventual ocorrência de um <dutch diseases, as tarifas e a política monetária afetam a taxa de câmbio real. Em particular, o déficit público em expansão, devido ao elevado conteúdo de salários, acarreta uma apreciação do câmbio real. [...]. - (CE, 08-94, p. 187, c. 2)

- [ID: 1466] - Setubal ressalta que está em pauta a criação de uma comissão para discutir os fundos multimercado, outra para representar os private banking - que hoje só tratam seus assuntos em reuniões informais - e um fórum de <"compliance"> voltada para atividade de asset management; "A expectativa é que com essa comissão de compliance, prevista para setembro, as coisas caminhem até para a auto-regulamentação", disse. [Tatiana Cristina da Silva] - (GM, 13, 14 e 15-08-04, p. B.2, c. 2)

No contexto abaixo, surgem dois estrangeirismos cuja compreensão exige um razoável conhecimento em inglês da terminologia envolvida:

- [ID: 2442] - O grande desafio é evitar que esse venha a ser um movimento abrupto, acarretando graves conseqüências financeiras sobre os agentes altamente alavancados e com o risco de que os bancos façam um <"credit crunch">. Nessa eventualidade, desapareceria a liquidez de todos os mercados de risco, inclusive os emergentes. Por isso, o "soft landing" não se completará sem que os bancos centrais 
do G-3 cooperem estreitamente para evitar uma perigosa maxidepreciação da moeda americana. - (FSP, 13-08-00, P. B.2, c. 6)

\section{4) Há contextos em que o emissor justifica a utilização do estrangeirismo.}

Alguns termos provêm das economias centrais e vão chegando paulatinamente ao Brasil. O emissor da mensagem se vê compelido a empregar o termo original porque ainda não existe equivalente na língua de chegada ou porque quer realçar o prestigio da informação. No exemplo abaixo, enfatiza o fato de que o termo representa instituto ainda não totalmente compreendido no Brasil.

- [ID: 1533] - Para complementar a função fiscalizadora e reguladora do Estado, a proposta prevê <"golden shares">, um instituto ainda não totalmente compreendido no Brasil. Não se trata de poderes ilimitados do Estado, mas sim certas salva guardas, previamente negociadas com a sociedade e com os investidores, para garantir que a qualidade do serviço ou o acesso de consumidores à eletricidade não se faça de forma discriminatória, reforçando e aliviando as funções do Estado. Além disso, as <"golden shares"> deverão coibir a cartelização e a revertilização, fortalecendo a competitividade e a justa concorrência como linhas diretoras da eficiência, da redução de custos e do aprimoramento da qualidade de serviço. - (FSP, 22/10/95, Finanças, p. 2, c. 5-6)

Caso semelhante consta do exemplo seguinte, em que o emissor parece que se desculpa por usar termos estrangeiros, mas prega parcimônia (bom senso) desse uso, e acaba por usá-lo, em nome de suposta maior riqueza do termo. O vernáculo não seria suficiente.

- [ID: 1503] - Misumi trabalha em um banco britânico e diz que "tem de haver bom senso no uso de termos estrangeiros". Segundo ele, os especialistas do mercado financeiro estudam os mercados de países mais desenvolvidos, especialmente o dos EUA, e acabam adotando sua terminologia. "Alguns termos nem têm tradução, expressam um conceito. É o caso de <'disclosure'>, que é a política de uma empresa de bem informar o mercado", comenta ele. "Poderia ser substituído por transparência, mas não resolveria". - (FSP, 13-11-00, p. F.7, c. 3-4) 
No exemplo abaixo, o estrangeirismo complementa o vernáculo, mas parece que o emissor usa um hipônimo em português e estabelece uma equivalência com um hiperônimo em inglês.

- [ID: 1687] - Segundo Pércio de Souza, do BBA, a fusão das corretoras teve por princípio unir duas frentes distintas. O Icatu sempre possuiu grande capilaridade na distribuição de serviços. E o BBA, tradição no preparo de análises (<"research">) para clientes. - (FSP, 04-06-00, p. B.10, c. 5)

\section{5) Sintagmas português + inglês}

Há casos em que o estrangeirismo se acopla a um termo em vernáculo formando um sintagma com elementos ingleses e portugueses, a saber:

- [ID: 2685] - Stuhlberger - Era um estrategista, fazia arbitragens (operações que buscam ganhos com a diferença de preço de determinado ativo em diferentes mercados). Nunca fiz um <"trading direcional"> (operações curtas que pressupõem uma direção específica do mercado, de alta ou de baixa). Parti da hipótese de que o mercado tinha tantas imperfeições que, sem arriscar quase nada, oferecia excelentes oportunidades de ganhar dinheiro. - (FSP, 30-08-99, p. 2.5, c. 2)

- [ID: 2612] - Executivo de sucesso no <bigbusiness corporativo>, o secretário do Tesouro dos Estados Unidos Paul O'Neil não tem o direito profissional de ignorar as diferenças entre as economias do Brasil e da Argentina. Ou entre as economias da Alemanha e da Inglaterra. - (ESP, 25-04-01, P .B.2, C. 3)

- [ID: 4387] - As empresas que mais pagam dividendos no Brasil. O destaque ficou por conta das instituições bancárias que apresentaram um < dividend yield médio> de 14,8\% nos últimos quatro anos. - (CE, 10-94, p. 29, subtít.)

- [ID: 1037] - "Para mudar a situação, Pratini tem duas propostas: a) criação do que chama de <drawback> "verde-e-amarelo": a compra de matérias-primas e componentes no mercado interno ficaria isento de impostos, como na importação (...). - (FSP, 15-06-97, p. 2.10, C. 6)

- [ID: 218] - Apesar dos avanços assinalados até aqui, faltam reformas definitivas que permitam ao setor privado participar no setor de serviços de comercialização e fazer 
investimentos mais seguros. (...) A importância destas reformas, que substituiriam com vantagem os preços mínimos, se prende ao fato de que, com bolsas e operações bursáteis(?) mais eficientes, a agricultura pode competir mais eficientemente em termos de custos (ser mais <cost effetive>), com preços de insumos e produtos indicando ajustes necessariamente mais rápidos. A agricultura tem potencial de ajuste, mas depende de preços que sinalizem o que tem que ser ajustado. - (CE, 0994, p. 38, c. 3)

- [ID: 2545] - Além das notícias (<clippings> e direto da redação), o portal continua publicando o Marinha Mercante todas às quartas, como já é usual. Portanto, o jornal continua existindo, só que agora na mídia eletrônica, e quando forem edições especiais, circulará dentro do caderno de economia do Estadão. - (ESP, 18-04-01, p. B.21, C. 5)

\section{6) O E integrado na frase}

- [ID: 1274] - Está claro, contudo, que se o Brasil não fizer um enorme ajuste fiscal, acabará sendo rebaixado. Hoje, o Brasil já está metido numa "armadilha da dívida", reconhece Gallagher. Ou seja, o déficit fiscal é alto porque os juros são altos e os juros são altos porque o déficit é alto. Qual a saída? Exagerar para mais (<"overshoot">) o ajuste fiscal, diz Gallagher, como fizeram outros países na mesma situação. Produzindo um superávit primário (receitas menos despesas, exceto juros) significativo. Quanto? "O importante não é só o tamanho, mas também a qualidade e a profundidade", responde. "O Brasil tem um problema de credibilidade", diz. Na medida em que possa reverter essa percepção, os juros poderão cair e o déficit, melhorar. Isso exigiria, a seu ver, além de ajustes fortes de curto prazo, especialmente nos gastos, aprovar a reforma da Previdência, a legislação para implementar a reforma administrativa e encaminhar a reforma tributária. - (FSP, 23-09-98, p. 2.5, c. 5)

\section{7) O "brasileiro" chama o E.}

Aqui o emissor incorpora a "nacionalidade" do estrangeirismo, ou seja, fala como um estrangeiro, ao dizer o que a gente chama ( e cita o termo em inglês) e não como eles chamam ou "como dizem os ingleses". 
- [ID:804] - "Sakagushi - Normalmente, é preciso ter uma empresa fechada. O que a gente chama, em inglês, de "<fronting>". - (FSP, 05-04-98, p. 2.3, c. 5-6)

\section{8) Recorre-se ao inglês, igualando-se o inglês e a economia}

A explicação de um fato econômico é dada, invocando-se, ao mesmo tempo a terminologia econômica e a língua inglesa. É como se o conhecimento do econômico ocorresse em inglês.

- [ID: 406] - "Os supermercados compram a prazo e vendem à vista. Compram por 10 (preço embutia um custo financeiro), vendem por 8 e buscam mais do que a diferença no mercado financeiro (o que os economistas chamam de <floating>). "Se supermercados e fornecedores tivessem repartido o <floating>, o ajuste não teria sido pago, em parte, pelo consumidor. - (FSP, 12-06-94, p. 2.4, c. 2)

\subsection{O Discurso Jornalístico}

No jornalismo dedicado à economia, um dos principais problemas de linguagem, diz Kucinski (1996:167), está no fato de ele se dirigir a pelo menos dois públicos bem diferenciados, que se comunicam por códigos próprios: de um lado, especialistas, grandes empresários e profissionais do mercado; de outro, o grande público e os pequenos empresários. O grande público e os pequenos empresários sentem-se permanentemente agredidos pela linguagem técnica inevitavelmente usada no jornalismo econômico. Os mecanismos principais da economia não são necessariamente complexos numa primeira aproximação, mas há detalhes, às vezes importantes, de explicação difícil. Freqüentemente, as próprias fontes do mercado alimentam uma aura de mistério em torno de suas transações, disseminando expressões exóticas.

A linguagem é também constitutiva de quem a formula, envolve todo o processo de estruturação do saber e do conhecimento de cada um e do coletivo. Os economistas apenas aparentemente usam a linguagem comum. De fato, eles a codificam em linguagem científica, na qual não apenas os argumentos são lógicos, mas também seus conteúdos são constituídos de sistemas lógicos, conceitos, relações e leis econômicas. É como se houvesse um outro 
argumento embutido dentro do argumento que está sendo explicado. Se o jornalista está se dirigindo ao grande público, não pode adotar essa linguagem, que não será entendida. Também seu referencial não é o mesmo do economista, e sim o dos interesses gerais da população. Além de acessível, o tratamento da informação deve ser crítico. O desafio do jornalista está em reportar e analisar, transmitir opiniões de economistas e governo, sem usar linguagem que as pessoas comuns não entendam, e sem violar os conceitos criados pela linguagem dos economistas.

A imprensa escrita cumpre um importante papel na difusão e eventual aceitação do estrangeirismo e sua transformação em empréstimo. A área da economia é uma das mais beneficiadas com a introdução de novos termos que passam do uso especializado ao uso comum em virtude da rápida difusão dos meios de comunicação. $\mathrm{O}$ estrangeirismo torna-se imprescindível na comunicação. Mesmo um autor como Perini (apud Faraco 2004:98), que julga que o exagero no emprego de empréstimos levado a extremos tem a desvantagem de desfigurar o texto com um excesso de termos de aspecto estrangeiro, admite a existência de palavras de origem estrangeira como o "menor dos males" e conclui que o "...o maior perigo está em não acompanhar, de maneira alguma, o desenvolvimento internacional do léxico". Faraco (2004:99) lembra que nos textos autênticos elaborados por especialistas em diferentes campos do conhecimento e publicados em revistas, os próprios empréstimos estrangeiros pelos diferentes autores aparecem "espalhados" no texto e nem sempre são as palavras de maior freqüência. Mas devem receber um tratamento de apresentação.

Lyons (apud Penagos, 1999:50) adverte que o semanticista "deve assegurar-se de dispor de vocabulário técnico e das convenções notacionais necessárias para estabelecer a distinção entre o uso reflexivo e o uso não reflexivo (ou normal) da língua”.

Os enunciados metalingüísticos são freqüentes em alguns textos de especialidades e preenchem função vital nos processos de consolidação de conhecimento das disciplinas científicas. Para que a comunicação se processe, pressupõe-se um tácito acordo denominativo que na linguagem cotidiana não representa um problema maior, já que o falante médio adquiriu uma certa fluidez da língua; na linguagem de especialidade, todavia, não se pode pressupor esse acordo tácito tendo em vista a permanente introdução de novos conceitos e 
referentes teóricos bem como a descrição de novos fenômenos inerentes ao progresso científico. Diferentemente da linguagem cotidiana, a linguagem técnico-científica almeja uma sistematização e estruturação que evite a ambigüidade permitindo a construção de enunciados teóricos que veiculem significados acessíveis para a comunidade de especialistas da área. Para Penagos (1999), de onde retiramos algumas destas observações, apesar de se ter escrito muito sobre os mecanismos formais da neologia no discurso especializado, não se tem estudado tanto o caráter discursivo e lingüístico de textos em que se refere à consideração do leitor não apenas um novo termo ou um novo sentido especializado para uma unidade lingüística já em uso, mas também que proporciona uma valorização, uma instrução interpretativa, uma remissão à fonte, ou uma informação enciclopédica sobre algum elemento do código comunicativo.

Embora seja possível na prática fazer um seguimento preciso para cada termo, existe, em teoria, para cada termo um desenvolvimento semiogenético que pressupõe em um dado momento, em algum texto concreto, que esse termo que agora se usa de maneira normalizada foi objeto alguma vez de uma operação metalingüística, seja por um texto fundante, seja em um glossário especializado ou em um contexto diferente do atual (quando se trata, por exemplo, de empréstimos de outras áreas), em razão do que é possível postular que todos os termos têm uma origem textual metalingüística na qual fundamentam sua origem semântica original ou seu valor comunicativo e que todos os termos (ou quase todos) sofrem uma evolução, submetem-se a processos modificativos que os transformam sincronicamente e que os fixam diacronicamente. Essa afirmação, obviamente, tem caráter apenas especulativo, já que não há corpora exaustivos que permitam validá-la.

As operações metalingüísticas não constituem o universo integral de operações discursivas em que se põe em questão o uso significativo de termos ou de noções ou conceitos a eles vinculados. São simplesmente as instâncias em que isso se faz de maneira explícita, embora nem sempre ocorra de maneira evidente em uma leitura superficial.

A incrustação de uma metalinguagem $\mathrm{L}_{1}$ (de ordem semiótica superior) em uma linguagem L deve realizar-se oferecendo pistas de processamento e interpretação adequadas, sob risco de tornar-se incompreensível à enunciação se não houver marca clara. Os 
marcadores lexicalizados mediante palavra, termo, expressão ou sinais de pontuação como aspas operam como classificadores ou descritores que obrigam a considerar os itens que os seguem como signos lingüísticos.

Ao serem usados metalingüisticamente, os itens lexicais têm suas marcas morfossintáticas neutralizadas. A explicação de Coseriu (1986:107) é que
"todo elemento significante da linguagem primária [...] pode converter-se em nome de si mesmo - e, por conseguinte, um substantivo - no plano da metalinguagem".

\section{Marcadores}

Os marcadores, num sentido lato, consistem em uma série de elementos verbais e não verbais que desempenham um papel revelador, de sinalização, quanto à produção do texto, durante a sua elaboração. Indicam e/ou estabelecem uma ligação tanto entre segmentos lingüísticos quanto entre as formas lingüísticas e o contexto. Freqüentemente, têm o caráter de marcadores de reformulação com o objetivo de fornecer explicações suplementares.

Alves (1984(1):97) lembra que o termo estrangeiro que imprime um caráter de novidade ao texto pode ser decodificado se for acompanhado de elementos que o explicitem. Esse recurso revela, na verdade, que o termo estrangeiro é externo à língua. Corresponde à fase em que é considerado estrangeirismo, isto é, tem função de produzir um efeito exótico, de cor local. É empregado eventualmente e possui, muitas vezes, o caráter metalingüístico de uma citação. Em alguns casos, prossegue Alves, o termo estrangeiro contém uma informação mais importante que a transmitida pelo elemento vernáculo. Os termos técnicos têm sido considerados como estrangeirismos necessários, em oposição aos supérfluos.

Como os estrangeirismos provêem geralmente de um país de cultura dominante, afirma Sauvageot (apud Alves, 1988:7), tendem a impor-se: o jornalista econômico sente-se como que compelido a adotar o estrangeirismo ou por causa do prestígio que o termo carrega consigo, ou por não encontrar equivalente satisfatório no vernáculo. Ao mesmo tempo, tem a 
consciência de que se trata de termo externo ao código o que pode resultar num choque ao destinatário que desconheça o significado do termo. Além do mais, o jornalista nem sempre domina a língua estrangeira portadora do estrangeirismo e acaba tendo que avaliar a adequação do termo. Para amenizar todos esses efeitos, recorre a formas de apresentação as mais variadas como marcadores, descritores, definições, traduções etc., metalinguiísticas ou não, objetivando tornar mais explícito e compreensível o termo empregado. Daí a necessidade de reformulação do texto.

Authier-Revuz chama de heterogeneidade mostrada as formas lingüísticas de representação do sujeito. São formas que inscrevem o outro na sequiência do discurso (discurso direto, aspas, formas de retoque ou de glosa, discurso indireto livre, ironia). Articulando à noção de dialogismo bakhtiniano a de "heterogeneidade constitutiva" da linguagem, ressalta o fato de o sujeito, enquanto parte de um corpo histórico-social, interagir com outros discursos. É o discurso como produto do interdiscurso. Nesse sentido, AuthierRevuz evidencia, como pistas do interdiscurso, as formas marcadas da heterogeneidade mostrada que se opõem a uma aparente linearidade do discurso.

Em nosso corpus de análise, pretendemos detectar, descrever e analisar essas formas de apresentação.

\subsection{Categorização das Formas de Apresentação}

Detectamos 229 tipos diferentes de enunciação e, em seguida, agrupando as características mais comuns de cada tipo em categorias, constituímos 9 categorias, conforme abaixo:

1. Recursos Gráficos: Tipos que utilizam recursos gráficos foram agrupados em uma mesma categoria. Por exemplo, "E” (ㄹef. port.); "E”, tradução; “port." ("E"), constam dessa categoria.

Este exemplo utiliza dois sinais gráficos: aspas e parêntese: 
- [ID: 1275] - As avaliações de risco de crédito (<"rating">) feitas pelas agências internacionais especializadas nessa atividade servem de parâmetro para que os investidores externos façam seus negócios, como comprar títulos de um país ou de uma empresa. - (FSP, 19-03-00, p. 2.9, c. 1)

2. Estrangeirismo tout court: $\mathrm{O}$ estrangeirismo é registrado sem qualquer referência ao fato de ser estrangeirismo, sem qualquer comentário. Esse tipo é o que ocorre com maior freqüência no corpus (190 contextos, representando $19,75 \%$ do total) e constitui outra categoria. Exemplo:

- [ID: 44] - A decisão do tribunal foi desfavorável ao Brasil porque na interpretação dos juízes o argumento brasileiro está baseado no marco normativo sobre <antidumping>, ainda não incorporado pelas legislações nacionais dos países membros, portanto, não pode servir de base para o julgamento. - (ESP, 23-05-01, p. B.12, C. 4)

3. Tradução: quando há tradução contida no contexto. Exemplo:

- [ID: 1761] - Os americanos ainda ganham e gastam demais. Os EUA só preparam o trem de pouso para o <"soft landing">, a aterrissagem suave da economia, embora neste mês as Bolsas tenham se animado com indícios de crescimento menor. (Marcio Aith e Ricardo Grinbaum) - (FSP, 11-06-00, p.B.1, c. 1-2)

4. Modos de Dizer: são os tipos que se enquadram nos modos de dizer, conforme observados por Rey-Debove (1978:267).

Os modos de dizer no sistema semiótico da conotação autonímica são os modos caracterizados pela relação entre o enunciador e a fonte das palavras conotada. Rey-Debove enumera modos de dizer os mais diversos, como: como ele diz, como você diz, como se diz, como dizem os pedantes, como dizem os entendidos, como dizem os ingleses, e também, como eu digo. Cada modo constitui um problema de caráter lingüístico ou sociolingüístico.

O modo como dizem alguns dá conta dos enunciados bilíngües ou inteiramente expressos em $\mathrm{L}_{2}$. Os modos de dizer são explícitos (comentários metalingüísticos) ou não (aspas, entonações). Os modos de como eles dizem (por exemplo, como 
dizem os ingleses) remetem a outros falares (regionais, arcaicos, raciais, profissionais etc); há o modo de dizer estrangeiro a $\mathrm{L}_{1}$, pois permite a penetração de duas línguas no discurso e força a barreira da aceitabilidade às custas do empréstimo.

No exemplo abaixo ocorre um interessante caso de paralelismo: como se diz em inglês se contrapõe a como se diz por aqui. Aqui não há resquício da suposta superioridade do estrangeirismo: lá a expressão é uma, aqui é outra, simétrica:

- [ID: 2032] - Como as ações não foram pulverizadas na Bolsa e como não existe o menor risco de "take over" ou de definir bônus em razão do aumento de preço das ações na Bolsa, não se tornaram, de fato, <"public corporations">, como se diz em inglês, ou empresas de capital aberto, como se diz por aqui. - (FSP, 17-05-99, p. 3.2, c. 4)

No exemplo a seguir há uma inversão: ao tentar traduzir o estrangeirismo há um efeito contrário, pois parece que encolhimento é como se diz em inglês, na realidade downsizing é como se diz em inglês:

- [ID: 493] - Tanto nas privatizações de estatais como nas fusões e consolidações de empresas é comum a redução significativa do número de empregados, o <"downsizing"> (encolhimento, como se diz em inglês). Seria interessante que alguma pesquisa universitária ou jornalística investigasse se esse processo conduziu no Brasil à criação líquida de empregos ou acentuou a desocupação." - (FSP, 30-05-99, p. 2.2, c. 3)

5. Verbos Metalingüísticos: Este tipo inclui verbos como ser, metalingüístico por excelência, verbo típico da definição por equivalência, que mostra uma relação equivalente entre o termo e o seu respectivo enunciado reformulador.

Outros verbos como representar, explicar, definir também ocorrem no corpus:

- [ID: 3236] - Para Hélcio Kronberg, do Lorremolinos, turista que vai ao exterior deve dar preferência ao <traveller's cheque>... O traveller é aceito como moeda corrente 
e evita o pagamento de comissão nas trocas pelo dinheiro do país. - (FSP, 18-069-94, p. 8, c. 3)

- [ID: 391] - As <factorings> são empresas que trocam cheques e duplicatas, mas, segundo a Justiça Federal em Cuiabá (MT), as de Arcanjo viraram bancos funcionando sem autorização do Banco Central, o que é crime contra o sistema financeiro, previsto na lei 7.492/86. - (FSP, 17-09-04, p. A.8, c. 1

Outros verbos como consistir, constituir, exprimir, representar, considerar como, exercem também a função de estabelecer uma equivalência. Exemplos:

- [ID: 3367] - As operações de <relending> (reempréstimo de recursos externos) ficariam restritas apenas ao setor estatal. De acordo com a análise técnica, esse tipo de operação não constitui pressão adicional sobre a base monetária (emissão de moeda), porque as empresas públicas já vêm rolando sistematicamente suas dívidas, o que, na prática, é o mesmo processo do <relending>. [Silvia Faria]. - (G, 27-11-88, p. 37, c. 3-4)

- [ID: 322] - A Folha apurou junto à Nasdaq que, até o final do ano, pelo menos outras 15 empresas brasileiras vão negociar suas ações na Bolsa eletrônica, das quais 13 ou 14 serão brasileiras "naturalizadas" norte-americanas. Isto é, apenas uma ou duas emitiriam ADRs (<American Depositary Receipts>), certificados que representam ações estrangeiras no mercado dos EUA, não podendo ser negociadas diretamente na Nasdaq. - (FSP, 07-05-00, p. 2.1, c. 1)

6. Recursos Metalingüísticos Explícitos: Um desses recursos, observa Alves (2005:166) é revelado quando uma palavra metalinguística (termo, expressão,...) introduz uma unidade lexical metalingüística de cunho autonímico. Este recurso permite, assim, que palavras autonímicas sejam inseridas no discurso. Exemplo:

- [ID: 2690] - A expressão "queima de capital", associada a crises em que há destruição em grande escala de empresas e países, ganhou na semana passada uma expressão concreta, numérica. Bancos e investidores perderam US\$350 bilhões, quase metade do PIB brasileiro, apenas ao longo de 1997 e 1998. Os dados foram divulgados na última sexta-feira pelo <"International Institute for Economics"> (<||E>), 
entidade que representa 300 instituições financeiras privadas do mundo todo. - (FSP, $19-09-99$, p. 2.2, c. 1)

7. Conotação Autonímica: Rey-Debove (apud Alves, 1984(1):99), denomina conotação autonímica do estrangeirismo quando o elemento do código estrangeiro é empregado simultaneamente com a unidade lexical pertencente ao código vernáculo, sem a intermediação de verbos metalingüísticos. É o uso de sinônimos (entre os dois códigos), formas perifrásticas ou definicionais que tornam o termo estrangeiro conotativamente autonímico.

A conotação autonímica transparece também, lembra Alves (1988:99), nas mensagens em que o elemento estrangeiro, empregado sem a ocorrência do termo vernáculo, aparece com marcas gráficas, como aspas, itálico. Uma vez desaparecidas tais marcas, o estrangeirismo, que infringe simultaneamente a norma e o sistema de uma língua, continua a autora, está em vias de incorporar-se à língua portuguesa e tornar-se um empréstimo, um elemento aceitável pela norma.

- [ID: 2832] - Apesar do recente otimismo que atingiu os mercados com o fim do processo eleitoral no Brasil, um quadro extremamente negativo do país está sendo exposto por companhias estrangeiras na SEC (<Securities and Exchange Commission>), a comissão de valores mobiliários americana. [Marcio Aith] - (FSP, 1711-02, p. B.1, c. 1)

8. Manifestação do discurso do outro: pode assumir diferentes formas, tanto no discurso científico quanto no de divulgação. Essa consideração ao discurso do outro é comum nas referências a outras línguas, a outros níveis de discurso, a outros discursos técnicos, a outras acepções de uma unidade lexical - no sentido estrito ou literal, ou figurado, conforme observa Alves (2005:168), apoiando-se em Authier-Revuz (1994). Designar e chamar-se, ou seus equivalentes - especialmente ser o nome de, para o primeiro, nomear-se, denominar-se, ter como nome, para o segundo implicam a marca da autonímia (Rey-Debove, 1978:186). 
É também, refere Alves (2005:168), por meio do verbo chamar, em seu emprego participial, formulaico - a maneira de batizado de, conhecido como,...- que unidades lexicais autonímicas são introduzidas e processa-se, então, a nomeação. Assim a esta categoria pertencem os tipos que contêm palavras ou expressões metalingüísticas, como, por exemplo, "conhecido como", "o chamado", "os iniciados chamam de" etc. Estes recursos permitem que palavras autonímicas sejam inseridas nos discursos. Alguns exemplos:

apelidadas, apelidado:

- [ID: 109] - [...] Com as taxas de juros vigentes no período, isso levou muitos desses fundos a atuarem de forma cautelosa, muitas vezes realizando operações casadas nesses mercados (apelidadas "operações de <box>"), que se caracterizavam por, na prática, serem operações de renda fixa. - (CE, 01-96, p. 25, c. 1)

- [ID: 2839] - No caso do equilíbrio orçamentário, a questão mexe com um dos tabus da <Euroland>, como foi apelidado o conjunto dos 12 países que adotarão a nova moeda. - (FSP, 30-09-01, p. B.3, c. 4)

das chamadas 〈hard bid>, ou concorrências públicas, de acordo com o jargão local:

- [ID: 4533] - Não foi sempre assim, é claro. Em 1991, a Odebrecht teve de entrar pela porta dos fundos das empreitadas americanas, atuando no ramo das chamadas <hard bids, ou concorrências públicas, de acordo com o jargão local. Nesse mercado, leva o contrato quem, simplesmente, oferece o melhor preço. Além disso, o governo americano exige que para disputar uma concorrência, as construtoras contratam seguradoras que emitam apólices de $100 \%$ do valor da obra, os chamados performance bonds. Caso a construtora quebre no meio do caminho, cabe à seguradora arcar com os custos e contratar outra firma que termine 0 projeto. [Angela Pimenta] - (Ex, 18-09-02, p. 85, c. 1 e 2)

os iniciados chamam de:

- [ID: 4755] - É lucro na certa, sem arriscar dinheiro próprio. Ao primeiro sinal de que terão de repagar os empréstimos a juro mesmo marginalmente mais elevado, os 
especuladores apressam-se em capitalizar os ganhos, passando adiante os valores e provocando-Ihes a queda. É com isso os iniciados chamam de <"carry trade"> e é em relação a esse gênero de precaríssimo remédio que se criou o que Paulo Nogueiro Batista Jr. denomina incisivamente da "dependência e(x)terna" da economia brasileira. [Rubens Ricupero] - (FSP, 16-05-04, p. B. 2, c. 4)

Aqui surgem chamado de e batizado de:

- [ID: 1647] - O Senado norte-americano aprovou ontem uma profunda mudança no sistema de financiamento de campanhas eleitorais. Se aprovada pela Câmara e sancionada pelo presidente George W. Bush, a lei impedirá o crescente e ilimitado fluxo de doações de corporações e sindicatos, o chamado "soft money". Desde 1907, apenas pessoas físicas podem doar dinheiro diretamente a campanhas eleitorais, com um limite de US\$1.000. No entanto uma brecha legal tem permitido aos partidos políticos receber doações de empresas e de sindicatos e usá-las para financiar indiretamente campanhas de seus candidatos. Esse tipo de financiamento foi batizado de "soft money", em oposição ao <"hard money"> das pessoas físicas. "Isso vai nos tirar da perseguição obscena de dinheiro e nos levar de volta ao contato com as pessoas", disse o senador democrata Paul Wellstone. O projeto, redigido pelos senadores John McCain (republicano) e Bussell Feingold (democrata), também eleva o limite da contribuição realizada por pessoas físicas. Para entrar em vigor, contudo, a medida precisa receber o aval do presidente, rival de McCain e opositor do projeto de lei. Bush se beneficiou com cerca de US\$244 milhões em "soft money" e US\$ 447 milhões em <"hard money"> na campanha em que se elegeu, em 2000. (FSP, 03-04-01, p. A.17, c.1-2)

\section{conhecida:}

- [ID: 4530] - O processo que levou a Telecom Italia a sair da Brasil Telecom é um exemplo. Embora as partes não comentem detalhes da operação, um dos pontos acertados, segundo uma das pessoas envolvidas no acordo, foi que o lote de $19 \%$ do capital do qual os italianos abriram mão ficará aos cuidados de uma figura jurídica conhecida no direito anglo-saxão como <trustee>. O <trustee>, que numa tradução livre seria algo como um administrador de confiança, é transformado, por contrato, no dono do bem a ser administrado, seguindo as orientações do proprietário. [Consuelo Dieguez] - (Ex, 18-09-02, p. 72, c. 1 
no jargão econômico se designa como (também há ocorrências de jargão, jargão do mercado, jargão financeiro internacional, , jargão diplomático, no jargão de mercado se chama):

- [ID: 145] - À Folha, Haberfeld confirmou a operação, mas diz que se trata do que, no jargão econômico, se designa como "<hedge>". Ou, nas palavras do próprio Haberfeld: Agora, há de fato chances de que haja uma desvalorização do real depois da eleição e, na dúvida, estamos comprando dólares no mercado futuro, como proteção à companhia. - (FSP, 05-09-98 p. 2.6, c. 1)

o mercado conhece como:

- [ID: 1037] - "Uma das principais vantagens do modelo que está em montagem é a economia de custos. Atualmente, a Receita permite que qualquer empresa seja isenta de impostos ao importar produtos e reexportá-los com valor agregado lo mercado conhece esse processo como <"drawback">). Mas as empresas pagam as despesas de transporte para levar as mercadorias das alfândegas até as fábricas e vice-versa. " - (FSP, 30-07-00, p. B.1, c. 3-4)

9. Outros : este grupo reúne os demais não enquadrados nas categorias anteriores.

Estas categorias não são excludentes, pois muitos termos podem pertencer a mais de uma categoria. Assim, uma construção que utilize recursos gráficos poderá também conter uma tradução, pertencendo a ambas as categorias. No caso das categorias 4 a 8 , entretanto, elas englobam todas as palavras que contenham referências metalingüísticas. Como nosso objetivo foi o de detectar os recursos metalingüísticos empregados no uso dos estrangeirismos, isolamos essas categorias para fins de análise. 


\section{CONSIDERAÇÕES FINAIS}

Neste trabalho, propusemo-nos detectar e analisar a incidência de estrangeirismos no nosso corpus de divulgação, na área da Economia, bem como verificar que recursos e opções de apresentação regem a introdução dos estrangeirismos.

Verificamos que para a incidência constatada de 8,4\% de estrangeirismos, as estratégias de apresentação são variadíssimas. Conseguimos detectar 229 formas diferentes, entre fórmulas de recursos gráficos, de língua-objeto e de metalinguagem.

Foram as seguintes as formas de apresentação mais freqüentes encontradas no corpus:

1) estrangeirismo tout court, sem qualquer comentário: 19,750\% das ocorrências;

2) estrangeirismo entre aspas: $14,968 \%$;

3) estrangeirismo entre aspas, acompanhado de definição em português entre parênteses: 5,301\%;

4) estrangeirismo entre aspas com definiçãa em português: 4,885\%.

Conforme perguntávamos no objetivo deste trabalho, que recursos da língua (ou da metalíngua) são ativados para a legitimação (ou não) da apresentação de estrangeirismos? Constatamos que os recursos da metalíngua encontrados são mais individualizados e mais analíticos. Carregam geralmente uma marca cultural, ao se reportar ou a outra cultura ou a outra língua, especificando que se trata, por exemplo, de um jargão de certa profissão ou de outra nacionalidade. Trazem mais credibilidade, ao informar que já há grupos ou coletividades empregando o termo que está sendo apresentado.

Extrapola os limites deste trabalho uma pesquisa que certamente poderia responder muitas questões que os dados aqui levantados suscitam: qual a correlação entre a forma de apresentação do estrangeirismo e seu grau de integração na língua portuguesa? Ou seja, quais 
estratégias são ou seriam mais bem sucedidas? Haverá estratégias específicas para cada tipo ou classe de estrangeirismo?

A metalinguagem é simultaneamente um autoregulador da linguagem da comunicação e um dos fatores importantes na evolução das línguas, observa Rey- Debove (1978:23).

Os enunciados metalingüísticos são abundantes em alguns textos de especialidade e cumprem funções vitais nos processos de consolidação do saber, no âmbito das disciplinas científicas. Aprender a falar com os outros sobre algo implica um acordo tácito denominativo que, na linguagem cotidiana, não representa problema maior para os que já têm certa fluência na língua; faz parte da competência semântica do falante médio.

Em uma linguagem de especialidade, contudo, tal acordo não pode, simplesmente, considerar-se implícito, devido à constante introdução de novos referentes teóricos e à descrição de novos fenômenos indispensáveis para o avanço do conhecimento científico. A predicação sobre a língua, afirma Penagos (1999:6), também faz parte do processo de aprendizagem consciente que os candidatos a especialistas devem assimilar. Tal necessidade estende-se, igualmente, aos discursos de divulgação que veiculam os novos conhecimentos.

Construir lingüisticamente o enunciado ou, em sentido mais amplo, o texto, significa dar forma e organização linguiística a um conteúdo, a uma idéia, enfim, a uma intenção comunicativa, o que permite dizer que, na construção lingüística do enunciado, desenvolvemse atividades de formulação, conforme enfatiza Hilgert (2001:107). ${ }^{4}$ O emissor e receptor encontram se em uma situação de comunicação e cabe ao emissor buscar seu objetivo: o de que o receptor mostre uma certa reação; para isso, o emissor deve levar o receptor a crer no que o emissor formula. Deve, então, alcançar um objetivo anterior: o de que o seu enunciado seja lingüisticamente construído de maneira tal que se reconheça a intenção comunicativa do emissor. No caso do estrangeirismo, a intenção é a de trazer ao vernáculo um termo de outro código, distinto do código de chegada.. O estrangeirismo traz em si o caráter da estranheza,

\footnotetext{
${ }^{4}$ Na realidade, Hilgert faz tais considerações para segmentos conversacionais, mas parece-nos que, feitas as devidas adaptações, elas se aplicam também ao texto escrito.
} 
do insólito, da novidade. Geraldi coloca de maneira muito apropriada este aspecto da novidade. Em suas palavras:

"Na linha da história dos usos de recursos específicos, a ação sobre a linguagem é o lugar da produção de uma certa "novidade". Esta novidade poderá apagar-se no discurso em curso, no grupo, ou poderá espalhar-se de modo tal que o novo se torna o estabilizado em discursos subseqüentes. Neste sentido, a ação sobre a linguagem é produtora de novas determinações relativas da língua. [...] é responsável por deslocamentos no sistema de referências, pela construção de novas formas de representação do mundo (note-se a importância das metáforas, dos raciocínios analógicos, das combinações etc.) e pela construção de recursos gramaticalizados, atribuindo-lhes sentidos que, embora externos à gramática, são fundamentais enquanto "efeitos de sentido" no discurso." (Geraldi, apud Marinho, 2003:5).

Apesar do metalingüístico ser uma função da linguagem pela qual o falante toma o código que utiliza como objeto de descrição, como objeto de seu discurso (Dubois 1993:412), a metalinguagem, informa-nos Ordonez (apud Casardo Velarde et al, 2005:275), não possui uma gramática própria, nem estruturas sintáticas peculiares e autônomas. O ordenamento sintagmático é a própria linguagem-objeto, porque o fenômeno da metalinguagem circunscreve-se quase que exclusivamente ao campo do léxico. Os usos metalingüísticos são incrustações, engastes de signos especializados na tela sintática da língua comum. Idêntica estrutura funcional registramos em mamãe tem dois filhos e em mamãe tem duas sílabas. A gramática do uso metalingüístico deve, portanto, cingir-se a esses quistos ou incrustações.

Assim, os processos de metalinguagem não são extravagantes, mas pertencem também à própria língua, e são auxiliares no anúncio da novidade (do estrangeirismo); representam papel importante na estratégia de implantação dos estrangeirismos na língua receptora. Isto para quem julga que os estrangeirismos são bem-vindos (ou inevitáveis) para a língua que os recebe. Evidentemente, hoje, toda e qualquer discussão sobre estrangeirismos está sempre 
permeada pela dimensão política, já que para muitos eles vêm eivados de suspeição. Parecenos mais realista aceitar sua realidade lingüística e desenvolver nossa cultura para que ela também tenha seus estrangeirismos exportáveis.

Nesse sentido, parece-nos pertinentes as palavras de Cunha, para encerramos nosso trabalho:

"Na realidade, o problema do empréstimo lingüístico não se resolve com atitudes reacionárias, com estabelecer barreiras ou cordões de isolamento à entrada de palavras e expressões de outros idiomas. Resolve-se com o dinamismo cultural, com o gênio inventivo do povo. Povo que não forja cultura dispensa-se de criar palavras com energia irradiadora e tem de conformar-se, queiram ou não queiram os seus gramáticos, à condição de mero usuário de criações alheias" (Cunha, 1981: 31-2).

Em nosso corpus de análise, nota-se que o uso das fórmulas de metalinguagem propriamente ditas e dos modos de dizer cumprem a função de apresentar a novidade dos estrangeirismos. As fórmulas que consignam a manifestação do outro, como, por exemplo, como dizem os ingleses, ou como se diz, parecem-nos mais eficazes, como transmissoras de mensagens, do que a irrupção brusca do estrangeirismo (em sua modalidade que chamamos tout court), isolado e sem justificativa. Se há objeções por parte de alguns quanto à aceitação dos estrangeirismos, certamente os recursos metalingüísticos tornam o ingresso na língua receptora mais ameno, já que as fórmulas como que pedem passagem, pedem para entrar... 


\section{REFERÊNCIAS BIBLIOGRÁFICAS}

ADDA, J. As origens da globalização da economia. Barueri: Manole, 2004.

ALVES, I. M. (1) Metalinguagem e empréstimo na mensagem publicitária. Alfa - Revista de Lingüística, São Paulo, v. 28, n. 4, p. 97-100, 1984.

(2) A integração dos neologismos por empréstimo ao léxico português. Alfa - Revista de Lingüística, São Paulo, v. 28, n. Supl, p. 119-126, 1984.

Empréstimos lexicais na imprensa política brasileira. Alfa - Revista de Lingüística, São Paulo: 32: 1-14, 1988.

Neologismo. Criação lexical. Série Princípios. 2. ed. São Paulo: Ática, 1994.

Empréstimo nas línguas de especialidade: algumas considerações. Ciência da Informação, Brasília, v. 24, n. 3, 1995.

O conceito de neologia: da descrição lexical à planificação lingüística. Alfa - Revista de Lingüística, São Paulo: 40: 11-16, 1996.

Polissemia e homonímia: a perspectiva terminológica, In: da HORA, D.; CHRISTIANO, E. (Orgs.). Estudos Lingüísticos: Realidade Brasileira. João Pessoa: Idéia, 1999.

Em torno de um jargão técnico: o economês. In: HUDINILSON, U.et al. (Org.).

Dino Preti e seus temas: oralidade, literatura, mídia e ensino. 1 ed. São Paulo: Cortez, 2001, v. 1, p. 173-180.

Neologia na língua falada. In: PRETI, D. (Org.). Léxico na língua oral e escrita. São Paulo: Humanitas, 2003, v. 01, p. 261-277. 
O emprego da metalinguagem em diálogos jornalísticos. In: PRETI, D. (Org.)

Diálogos na fala e na escrita. São Paulo, Humanitas, 2005.

ASSIRATI, E.T. Neologismos por empréstimo na informática. Alfa, São Paulo, 42, 1998.

AUBERT, F. As Variedades de empréstimos. Delta, v. 19, no. spe, 2003. Disponível em: <http://www.scielo.br/scielo.php?script=sci_arttext\&pid=S0102-44502003000300004>, Acesso em: 24/04/2008.

AUTHIER-REVUZ, J. Ces mots qui ne vont pas de soi: boucles réflexives et noncoïncidences du dire. Paris: Larousse, $1995,1^{\circ}$. vol.

, Palavras incertas: as não-coincidências do dizer. Trad. Maria Onice Payer.

Campinas: Editora da UNICAMP, 1998.

, Da neologia à neologia na literatura. In: OLIVEIRA, A. M. P. P. DE \& ISQUERDO, A. N. (Orgs.). As ciências do léxico: lexicologia, lexicografia e terminologia. Campo Grande: UFMS, 1998.

BECHARA, E. Moderna gramática portuguesa. 37. ed. Rio de Janeiro: Lucerna, 2001.

BENVENISTE, E. Problèmes de linguistique générale. Paris: Gallimard, 1966, 10. vol.

BERGENHOLTZ, H.; TARP, S. Manual of specialised lexicography. Benjamin Translation Library. Amsterdam / Philadelphia: John Benjamins, 1995.

BIDERMAN, M. T. C. Teoria lingüística: lingüística quantitativa e computacional. Rio de Janeiro: Livros Técnicos e Científicos, 1978.

BOULANGER, J. C. Néologie et terminologie. Néologie en Marche, 4 (Série b: langues de spécialités), p. 5-128,1979. 
BOWKER, L.; PEARSON, J. Working with specialized language: A practical guide to using corpora. London: Routledge, 2002.

CABRÉ, M. T. La terminología teoría, metodología, aplicaciones. 1. ed. Barcelona: Empúries, 1993.

La terminología: representación y comunicación: elementos para una teoría de base comunicativa y otros artículos. Barcelona: Institut Universitari de lingüística aplicada / Universitat Pompeu Fabra, 1999.

Sur la representation mentale des concepts: bases pour une tentative de modelisation. In: BÉJOINT, H.; THOIRON, P. Le sens en Terminologie. Lyon: Presses Universitaires de Lyon, 2000.

CÂMARA JR., J. MATTOSO. Dicionário de filologia e gramática: referente à língua portuguesa. 6. ed. Rio de Janeiro: Jozon, 1974.

Dicionário de lingüística e gramática: referente à língua portuguesa. 8. ed. Petrópolis: Vozes, 1978.

CANO, W. M.; PRADO, D. de F. Os estrangeirismos da área da informática no Aurélio XXI. Rev. ALFA de Lingüística, São Paulo: 50 (2): 265-267, 2006.

CARVALHO, N. Empréstimos lingüísticos. Série Princípios. São Paulo: Ática, 1989. „Neologismos, informação e criatividade. In AZEREDO, J. C. de (Org.). Língua portuguesa em debate; conhecimento e ensino. Petrópolis: Vozes, 2000.

CASADO VELARDE, M.; GONZÁLEZ RUIZ, R.; LOUREDA LAMAS, Ó. (Ed.) Estúdios sobre lo metalingüístico. Frankfurt am Main: Peter Lang, 2005.

CHALHUB, S. A metalinguagem. São Paulo: Ática, 2002. 
CORRÊA DA COSTA, S. Palavras sem fronteiras. São Paulo, Record, 2000.

COSERIU, E. Lições de lingüística geral. Trad. Evanildo Bechara. Rio de Janeiro: Rio, 1980. . Princípios de semântica estrutural. Madrid: Gredos, 1986.

CUNHA, A. G. da. Os estrangeirismos da língua portuguesa: Vocabulário HistóricoEtimológico. São Paulo: Humanitas, 2003.

CUNHA, C. F. da. Língua portuguesa e realidade brasileira. 8. ed. Rio de Janeiro: Tempo Brasileiro, 1981.

CRYSTAL, D. The Cambridge encyclopedia of language. 2. ed. New York: Cambridge University Press, 1997.

DESMET, I. Questões de semântica em terminologia: a problemática da definição terminológica. Terminologias. Disponível em: $<$ http:///www.scielo.br/scielo.php?script=sci_arttext\&pid==S010019652004000200009>, Acesso em: 26/03/08.

DUBOIS, .J. et al. Dicionário de Lingüística. 9. ed. São Paulo: Cultrix, 1993.

DUBUC, R. Manuel pratique de terminologie. Montréal: Linguatech, 1978.

FARACO, C. A. (Org.). Estrangeirismos - guerras em torno da língua. 3. ed.. São Paulo: Parábola, 2004.

FERREIRA, A. B. de H. Novo dicionário Aurélio de língua portuguesa. Rio de Janeiro: Nova Fronteira, 1986.

Novo Aurélio do Século XXI: o dicionário da língua portuguesa. 3. ed. Rio de Janeiro: Nova Fronteira, 1999. 
FAULSTICH, E. Socioterminologia: mais que um método de pesquisa, uma disciplina.

Ciência da Informação, Brasília, v. 24, n. 3, 1995. Disponível em:

<www.ibict.br/cionline/include/getdoc.php?id=875\&article=529\&mode=pdf ->, Acesso em: 28/04/2008.

FELBER, H. Terminology manual. Paris: UNESCO, 1987.

GIDDENS, A. As conseqüências da modernidade. São Paulo: UNESP, 1991.

GUILBERT, L. La créativité lexicale. Paris: Larousse, 1975.

HELVÉCIA, H. Cada um com a sua língua. Disponível em:

<http://www1.folha.uol.com.br/folha/sinapse/ult1063u468.shtml $>$, Acesso em: 24/06/2003.

HILGERT, J. G. Procedimentos de reformulação: a paráfrase. In: PRETI, D. (Org.). Análise de textos orais. São Paulo: Humanitas, 2001, 5.ed., p. 103-127.

Norma Internacional ISO 1087. Terminology: vocabulary. ISO, 1990. Disponível em: $<$ http://www.iso.org/iso/iso_catalogue/catalogue_ics/catalogue_detail_ics.htm?csnumbe $\underline{\mathrm{r}=5591>}$.

Norma Internacional ISO 704: Terminology work: principles and methods. ISO, 2000.

Disponível em:

<http://www.iso.org/iso/iso_catalogue/catalogue tc/catalogue detail.htm?csnumber=31 696.>

JAKOBSON, R. Lingüística e comunicação. 6. ed. Trad. Isidoro Blikstein e José Paulo Paes. São Paulo: Cultrix, 1973.

KOCOUREK, R. La langue française de la technique et de la science. 2. ed. Wiesbaden: Brandstetter Verlag, 1991. 
KRIEGER, M. G. Terminologia Revisitada. Delta: documentação de estudos em lingüística teórica e aplicada, São Paulo, v.16, n. 2, 2000.

KRIEGER, M. G.; FINATTO, M. J. B. Introdução à terminologia: teoria e prática. São Paulo: Contexto, 2004.

KRIEGER, M. G.; MACIEL, A. M. B. (Orgs.). Temas de terminologia. Porto Alegre / São Paulo: Ed. Universidade / UFRGS / Humanitas / USP, 2001.

KUCINSKI, B. Jornalismo econômico. São Paulo: Edusp, 1996.

LARA, M. L. DE. G. Diferenças conceituais sobre termos e definições e implicações na organização da linguagem documentária. Ciência da Informação, Brasília, v. 33, n.2., 2004.

LAURIAN, A. M. L. Typologies des discours scientifiques: deux approches. Études de Linguistique Appliquée, Paris, 51, p. 8-20, 1983.

LAVAULT, E. Le métalangage de la traduction em quête de sens. Métalanguage et terminologie linguistique. COLOMBAT, B.; SAVELLI, M. (Eds.). Orbis/Suplementa, 17. Louvain: Peeters, 2001.

LERAT, P. Les langues spécialisées. Paris: Presses Universitaires de France, 1995.

MANZOLILLO, V. C. de O. Ainda em torno da dicotomia empréstimo / estrangeirismo. Disponível em: <http://www.filologia.org.br/revista/artigo/7(21)02.htm>, Acesso em: 21/08/2007.

MARINHO, M.: O discurso da ciência e da divulgação em orientações curriculares de língua portuguesa. Revista brasileira de educação, São Paulo, n. 24, set/dez. 2003. 
MEYER, I.; MACKINTOSH, K. «L'étirement» du sens terminologique: aperçu du phónème de la déterminologisation In: BÉJOINT, H.; THOIRON, P. Le sens en Terminologie. Lyon: Presses Universitaires de Lyon, 2000.

OPTIZ, K. On dicitionaries for special registers; the segmental dictionary. In: HARTMANN, R. R. K. (Ed.). Lexicography: principles and practice. Londres: Academic Press, 1983.

ORTIZ, Renato. Mundialização e cultura. São Paulo: Brasiliense, 2000.

PAUL, H. Princípios fundamentais da história da língua. 2. ed. Lisboa: Calouste Gulbekian, 1983.

PAVEL, S.; NOLET, D. Manual de terminologia. 2002. Disponível em: <www.translationbureau.gc.ca $>$, Acesso em: 18/03/2008.

PENAGOS, C. R. Operaciones metalingüísticas explícitas en textos especializados. Barcelona: Institut Universitari de Lingüística Aplicada, 1999.

PEREIRA, S. C. Renovação lexical: neologismos na imprensa diária escrita brasileira. Perspecto, 1, n. 1, 2001. Disponível em: http://www.institutounipac.com.br/perspecto/ano1nr1/12_renovacaolexical_neologismo snaimprensa.pdf, Acesso em: 29/04/08.

PRETI, D. A gíria na sociedade contemporânea. In: VALENTE, A. C. (Org.). Língua, Lingüística e literatura. Rio de Janeiro: UERJ, 1998.

REY, A. Essays on terminology. Amsterdam / Philadephia: John Benjamins, 1995.

REY-DEBOVE, J. Le métalanguage. Étude Linguistique du Discours sur le Langage. Paris: Le Robert, 1978.

ROCHA, A. Termos básicos de literatura, lingüística e gramática. Europa-América, 1997. 
RONDEAU, G. Introduction a la terminologie. 2. ed. Québec: Gaëtan Morin, 1984.

ROSETTI, A. Langue, mode et mélange de langues. Acta linguistica, 5:73-9, 1945-9.

SABLAYROLLES, J.-Fr. La néologie en français contemporain. Paris: Honoré Champion Éd., 2000, p.71-100; p. 145-163.

SAGER, J. A practical course in terminology processing. Amsterdam / Philadephia: John Benjamins, 1990.

SANTOS, V. P. R. A terminologia e o sistema de gestão de qualidade ISO 9000. Estudos lingüísticos, XXXV, p.1952-1959, 2006.

STERKENBURG, PIET VAN (Org.). Terminology and lexicography research and practice. Amsterdam / Philadephia: John Benjamins, 2003.

TAMBA, I. Autonymie, denomination et fonction metalinguistique. Disponível em: 〈http://www.cavi.univ-paris3.fr/ilpga/autonymie/tableronde/tambail.pdf $>$, Acesso em: $18 / 03 / 2008$.

WEINREICH, U. Languages in contact. Findings and problems. Haia: Mouton \& Co. N. V., 1974. 